\title{
ROSELANE GONÇALVES
}

\section{VIVENCIANDO O CLIMATÉRIO: O CORPO EM SEU PERCURSO EXISTENCIAL À LUZ DA FENOMENOLOGIA}

Tese apresentada à Escola de Enfermagem da Universidade de São Paulo, para obtenção do título de Doutor em Enfermagem.

Orientadora:

Prof. ${ }^{a}$ Dr. ${ }^{a}$ Miriam Aparecida Barbosa Merighi

São Paulo

2005 


\section{Catalogação na publicação (CIP)}

\section{Biblioteca "Wanda de Aguiar Horta” da EEUSP}

Gonçalves, Roselane

Vivenciando o climatério: o corpo em seu percurso existencial à luz da fenomenologia. / Roselane Gonçalves. - São Paulo: R. Gonçalves; 2005.

244 p.

Tese (Doutorado) - Escola de Enfermagem da Universidade de São Paulo.

Orientadora: Prof ${ }^{\mathrm{a}}$ Dr $^{\mathrm{a}}$ Miriam Aparecida Barbosa Merighi

1. Assistência de enfermagem 2. Climatério 3. Menopausa

4. Meia idade 5. Saúde da mulher 6. Fenomenologia. I. Título. 
Tudo posso n'Aquele que me fortalece!

Felipenses 4:13 


\section{A Deus,}

Pela minha vida, pela minha saúde e pelo meu aprendizado constante, no cotidiano do meu existir.Pela luz, pela sensibilidade e pela intuição, atributos que me auxiliam a perceber aquilo que se encontra além do visível. 


\section{Dedico este trabalho}

A meu pai Pedro (in memoriam), exemplo de firmeza nos propósitos e perseverança. Pelo amor incondicional, que mantém acesa em mim a fé e o respeito à vida.

A minha mãe Maria Izabel (in memoriam), que tão precocemente seguiu pelos caminhos imponderáveis do infinito. Pela paixão que alimentava pela vida e pela sabedoria com que conduziu a sua missão. Minha motivação permanente na trajetória como mulher, mãe e profissional. 
A minhas irmãs Rosana e Rosemary (Ananda), pela cumplicidade e reciprocidade amorosa.

A minha filha Moara, pelo significado que trouxe à minha vida e por fazer-me exercitar o amor incondicional e a aceitação.

Ao Mauro, meu companheiro e amigo, pela compreensão e presença constante e inquestionável. 


\title{
Agradecimentos Especiais
}

\author{
À Professora Livre-Docente Miriam \\ Aparecida Barbosa Merighi, pela confiança \\ e determinação com que conduziu a \\ orientação desta pesquisa. Pela crença \\ contagiante que nutre pela subjetividade \\ humana.
}

À Professora Doutora Maria de Fátima Prado Fernandes, pelo envolvimento e reflexões, que tanto enriqueceram as discussões dos achados deste estudo e, ainda, pela ternura que tranqüiliza ao mesmo tempo em que incentiva. 
Ao Professor Doutor Rui de Souza Josgrilberg, pelo encantamento contagiante pelos caminhos da Fenomenologia.

À Professora Doutora Clarice Heiko Muramatsu, pelo incentivo por ocasião da elaboração do Projeto desta Pesquisa, pela alegria e sensibilidade que sempre transmitiu pelo olhar e pelo seu trabalho.

À Professora Doutora Maristela Belletti Mutti Urasaki, amiga e referência para minha atuação profissional, pela sensibilidade e amorosidade que the são inerentes. 
À Professora, mestre de Yoga, Rosicley Gomes Lilliamtis, pela simplicidade e generosidade com que trilha seu caminho e pela maestria na criação da capa e ilustrações deste trabalho.

Ao Antonio Carlos Velloso, pela determinação com que segue o caminho em busca da Verdade.

A Rosana Gomes da Silva Rodrigues, pela parceria no dia-a-dia e pela dedicação constante. 
A Ana Maria de Araújo Macedo, amiga com quem aprendi a ponderar razão e emoção, firmeza e sensibilidade.

Às amigas, Débora Padovani Monteiro, Ana Lúcia Rotundo e Mônica de Almeida Faria, pela solidariedade e carinho constantes.

À amiga Mônica Sperandio, que pela simplicidade e confiança conquistou definitivamente meu coração. 
A Lourdes Barufaldi, amiga e incentivadora do trabalho inter, multi e transdisciplinar no cuidado à saúde das pessoas, pela leitura e reflexões sobre a temática.

Aos funcionários Marcelo, Rafael e Lívia, do Departamento de Enfermagem MaternoInfantil e Psiquiátrica, da Escola de Enfermagem da USP, pela presteza nos encaminhamentos durante a elaboração deste trabalho. 
A Nadir Aparecida Lopes, da Seção de Atendimento ao usuário, da Biblioteca da Escola de Enfermagem da Universidade de São Paulo, pela revisão e correções das referências bibliográficas.

A Professora Livre-Docente Maria Romana Friedlander, pelo incentivo e por ter confiado no meu trabalho durante a sua gestão no Curso de Graduação em Enfermagem da Universidade de Mogi das Cruzes. 
Ao Professor Doutor Jair Ribeiro Chagas, Diretor de Pesquisa, Pós-Graduação e Extensão da Universidade de Mogi das Cruzes, pela concessão da bolsa do Programa de Auxílio à Qualificação

Docente.

À Professora Joana D'Arc da Silva Costa, pela revisão do texto em língua portuguesa.

A Ártemis, Hera, Tique, Afrodite, Héstia, Deméter e Atena, participantes desta pesquisa, que fortaleceram em mim a crença na subjetividade, na espontaneidade e na natureza do Ser Mulher. 


\section{RESUMO}

GONÇALVES R. Vivenciando o climatério: o corpo em seu percurso existencial à luz da fenomenologia. [Tese]. São Paulo (SP): Escola de Enfermagem da USP; 2005.

Buscando compreender a vivência do climatério realizei pesquisa qualitativa de abordagem fenomenológica. As entrevistas foram realizadas com sete mulheres, entre 48 e 55 anos de idade, que apresentaram menopausa espontânea. Para desvelar a essência do fenômeno ser mulher vivenciando o climatério elaborei a questão norteadora: Fale-me, como é para você estar vivenciando o climatério? Dos depoimentos emergiram as Unificações Ontológicas: percebendo mudanças no seu corpo, vivenciando sentimentos de ambigüidade, conscientizando-se do mundo por meio do corpo no tempo e no espaço, refletindo sobre a sexualidade e reconhecendo novas maneiras de co-existir no mundo, que foram analisadas e interpretadas à luz do referencial teórico filosófico de Maurice Merleau-Ponty. Os resultados do estudo culminaram na elaboração de pressupostos para a pesquisa, o ensino e a assistência à mulher climatérica, que vão além do biológico, contemplando a dimensão humana existencial.

UNITERMOS: Assistência de enfermagem. Climatério. Menopausa. Meiaidade. Saúde da mulher. Fenomenologia. 


\section{ABSTRACT}

GONÇALVES R. Experiencing the climacteric: the body in its existential course under the light of the phenomenology. [Thesis]. Sao Paulo (SP): Nursing School, University of São Paulo; 2005.

Trying to understand the climacteric experience, I have accomplished qualitative survey of phenomenological approach. The interviews were accomplished with seven women, aged between 48 and 55, who have presented spontaneous menopause. In order to unveil the essence of the phenomenon "being woman experiencing the climacteric", I have prepared the guiding question: Tell me, how it sounds to you to be living the climacteric? Ontological Unifications arose from the testimonies: realizing changes in her body, experiencing feelings of ambiguity, becoming aware of the body in space and time, bethinking about the sexuality and recognizing new ways to co-exist in the world, which were analyzed and interpreted under the light of Maurice Merleau-Ponty's philosophical theoretical referential. The results of the study have culminated in the elaboration of presuppositions for the survey, the teaching and support to the climacteric woman, that go beyond the biological, contemplating the existential human dimension.

UNITERMS: Nursing attendance. Climacteric. Menopause. Middle-age. Woman's Health. Phenomenology. 


\section{RESUMEN}

Gonçalves R. Vivenciando el climatério: el cuerpo en su percurso existencial a la luz de la fenomenolofia. [tesis]. São Paulo (SP): Ecuela de Enfermeria de la Univercidad de San Pablo; 2005.

Buscando comprender la vivencia del climatério realize pesquisa cualitativa de abordaje fenomenológica. Las entrevistas fueron realizadas con siete mujeres, entre 48 y 55 años de edad, que presentaron menopausia espontánea. Para desvelar la esencia del fenomeno ser mujer vivenciando el climatério elabore la cuestión norteadora: Digame, cómo se siente vivenciando el climatério? De las declaraciones sobresalieron las Unificaciones Ontologicas: percibiendo mudanzas en su cuerpo, vivenciando sentimientos de ambigüedad, tomando conciencia del mundo por intermedio del cuerpo en el tiempo y en el espacio, reflexionando sobre la sexualidad y reconociendo nuevas maneras de coexistir en el mundo, que fueron analizadas e interpretadas a la luz del referencial teorico filosófico de Maurice Merleau-Ponty. Los resultados del estudio culminaron en la elaboración de presupuestos para la pesquisa, la instrucción y la asisténcia a la mujer climatérica, que va mas allá de lo biológico, contemplando la dimensión humana existencial.

Unitermos: Asistencia de enfermeria. Climatério. Menopausia. Media-edad. Salud de la mujer. Fenomenologia. 


\section{SUMÁRIO}

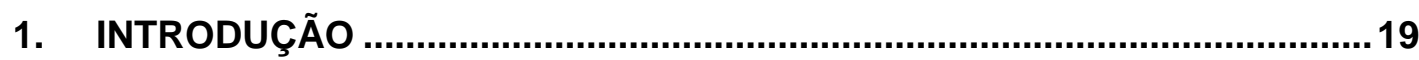

1.1 O despertar para a temática: inquietação e objetivo do estudo... 19

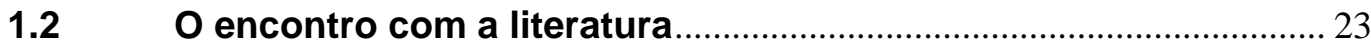

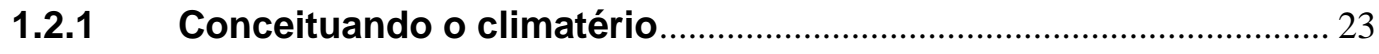

1.2.2 Situando o climatério no âmbito da Saúde Pública .......................... 30

1.2.3 Contextualizando o climatério: justificando o tema do estudo .... 38

2. ESCOLHENDO A ABORDAGEM METODOLÓGICA ..................................4 47

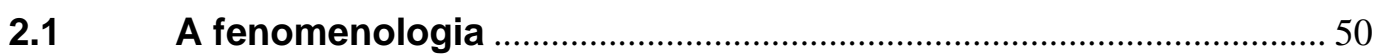

2.2 Falando sobre o referencial filosófico de Maurice Merleau-Ponty: o corpo visto com as lentes da fenomenologia ................................................. 56

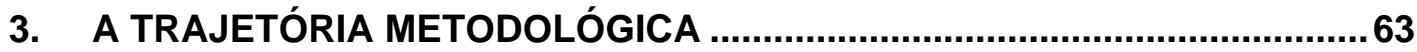

3.1 Os sujeitos da pesquisa, região de inquérito …………………........ 64

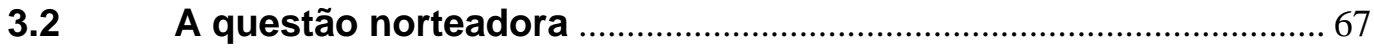

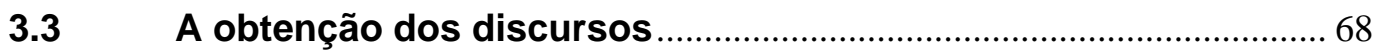

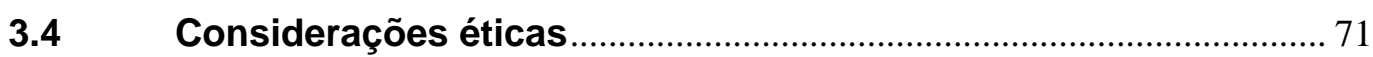

4. CONSTRUINDO OS RESULTADOS ............................................................ 73

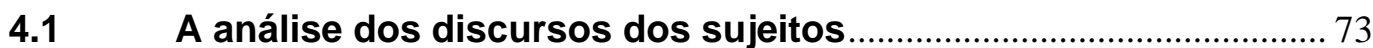

5. UNIFICAÇÕES ONTOLÓGICAS REFERENTES À MULHER VIVENCIANDO

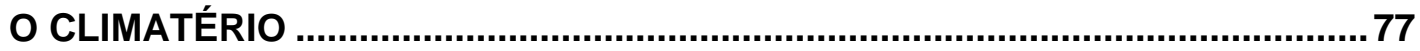

5.1 Percebendo as mudanças no seu corpo ……….............................. 78

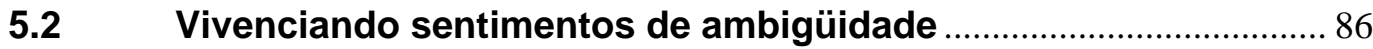

5.3 Conscientizando-se do mundo por meio do corpo no tempo e no

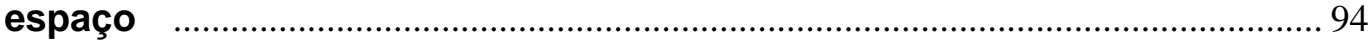

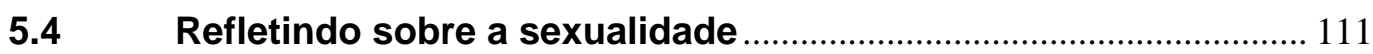

5.5 Reconhecendo novas maneiras de co-existir no mundo.............. 122

6. DELINEANDO MODOS DE CUIDAR DA MULHER NO CLIMATÉRIO ....... 135

7. REFERÊNCIAS BIBLIOGRÁFICAS .................................................... 147

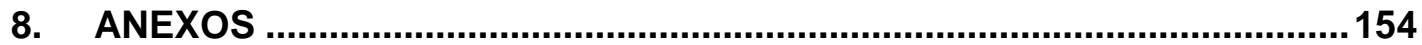




\section{INTRODUÇÃO}

\subsection{O despertar para a temática: inquietação e objetivo do estudo}

Após a graduação dediquei-me ao estudo da Enfermagem Obstétrica. Inicialmente, atuava somente na assistência à mulher durante o período gravídico-puerperal, exercendo paralelamente atividade docente no Curso de Graduação em Enfermagem, ministrando disciplinas diversas. Posteriormente, passei a acompanhar também alunos em suas atividades teórico-práticas na área da ginecologia e obstetrícia.

Desde aluna, chamava-me a atenção a maneira como eram tratados os "problemas de saúde das mulheres". Na maioria das vezes os profissionais, apesar de competentes tecnicamente, insistiam em referir-se às mulheres, internadas na unidade hospitalar, como "casos", "objetos" somente enquanto portadoras de patologias. Percebia que quando se tratava de intercorrências que poderiam ser "resolvidas" com terapêutica medicamentosa ou cirúrgica, as preocupações eram mais amenas, mas quando as queixas não podiam ser justificadas clinicamente, todos pareciam carecer de habilidades para obter soluções que extrapolavam o âmbito da tecnologia.

No entanto, o envolvimento profissional com as clientes tanto na assistência, quanto no ensino, seduzia-me. Compreender a vivência dos eventos do processo saúde-doença das mulheres, que estavam sob meus cuidados, era uma necessidade constante, uma vez que, no dia-a-dia da assistência, podia explicar apenas os processos fisiológicos vividos e suas 
necessidades visíveis. Sabia, porém, que algo mais perpassava todas as ocorrências. Algo que só poderia entender se ajustasse a lente do meu olhar.

A inquietação com a situação relacionada à vivência dos eventos de saúde-doença das mulheres, levou-me a desenvolver o tema da dissertação de mestrado: "Transforma-se enquanto mulher: um estudo de caso sobre a vivência do período pós-parto". Para a realização desse estudo optei pela metodologia qualitativa, pois estava voltada para a compreensão da experiência vivida (Gonçalves, 2000).

Quando despertou em mim o interesse pelo curso de doutorado, o tema escolhido foi o climatério e a preocupação, mais uma vez, incidiu sobre a compreensão da experiência da mulher durante essa fase da vida.

Dessa forma, durante a elaboração do projeto de pesquisa, fui incorporando a necessidade de conhecer melhor esse fenômeno que é vivido por todas as mulheres e que ocorre no meu próprio corpo e no contexto das minhas relações, seja no círculo profissional, familiar ou de amizade.

Observando mais atentamente as mulheres com quem tinha contato, notei por meio de suas falas que havia uma certa ênfase nas preocupações com as mudanças no seu corpo: a pele, as limitações físicas e a busca pela "correção" de detalhes na sua imagem corporal, como mudar o corte e a cor dos cabelos, fazer ginástica, usar cosméticos. Enfim, algo acontecia em seus corpos e isso era evidente. 
O que mais estava ocorrendo e até que ponto o espelho revelava todas as nuances desses corpos? $\mathrm{O}$ que acontecia na intimidade dessas mulheres? Nem tudo pode ser explicado pela Biologia. Haveria tratamento para tudo o que fosse necessário? O que a ciência proporia para cada uma delas? A ciência seria capaz de particularizar essas questões e avançar? Ainda não! Como os pesquisadores farão esse diálogo entre o que já foi desvelado pela ciência e a própria natureza humana que está em curso, mudando de acordo com os fenômenos sociais que serão constituídos de intersubjetividade? Natureza humana esta em que na objetividade deve ser considerada a subjetividade, que em cada mulher pode desencadear sinais e sintomas específicos, como uma experiência individual no climatério.

Todas essas perguntas talvez sejam respondidas ao buscar a essência da questão. Antes disso, no entanto, assistimos impotentes ao processo natural da vida. Luta-se contra este processo e, no fundo, sabe-se que maquiagens e operações estéticas podem tão-somente prolongar nossa juventude agonizante.

Passei, assim, a perguntar-me o que significa para mim viver este período da vida? Não tenho as ondas de calor, meus ciclos menstruais ainda são regulares, no entanto, percebo que algo em mim tem mudado a cada dia. Quem sabe seria a constatação de que estes eventos são prenúncios de um drama moral que se inicia antes que os fenômenos fisiológicos se declarem e termina quando eles já há muito desapareceram (Beauvoir,1980, p.343). 
Estudando a temática do climatério, pude perceber que a complexidade do processo de envelhecimento assume papel ímpar quando apreciado pela ótica feminina, cuja característica é a busca pelo detalhe, pelo que é específico, pelas minúcias. Implica em olhar com sensibilidade o desenrolar desta fase da vida.

Apreciando o fenômeno da "menopausa", sob a perspectiva de gênero, foi possível constatar que o homem envelhece de maneira contínua e a mulher o faz bruscamente, ou seja, ela se vê repentinamente despojada da feminilidade, além da fecundidade e o encanto erótico. A impressão que se tem é que aos olhos da sociedade e a seus próprios olhos perde a justificação de sua existência e suas possibilidades de felicidade (Beauvior,1980).

Às voltas com estas inquietações e envolvida com a temática da saúde da mulher, proponho esta pesquisa com o objetivo de compreender a vivência do climatério.

Sendo assim, julguei oportuno tecer algumas considerações sobre a temática em pauta, não sem antes salientar que essas colocações preliminares evidenciaram-se como uma aproximação com o fenômeno interrogado e para trazê-lo aqui, em forma de estudo, foi necessário que eu me "desarmasse", ou seja, que me desvencilhasse de pré-concepções, de teorias explicativas sobre o climatério, aprendidas em livros e cursos, para "ir às coisas mesmas", tal como se apresentava à minha percepção. 
Ao mesmo tempo em que coloquei de lado, temporariamente, o que sabia, considerei imprescindível perscrutar a literatura e apreender dela aspectos concernentes ao climatério, a fim de melhor conhecê-lo.

\subsection{O encontro com a literatura}

\subsubsection{Conceituando o climatério}

O termo climatério é comumente usado como sinônimo de menopausa. Enquanto este é um fenômeno que se define retroativamente, pois representa a cessação permanente das menstruações, por um período de doze meses de amenorréia, sendo o resultado da perda da função folicular dos ovários; aquele é utilizado para definir o período da vida reprodutiva da mulher durante o qual a menopausa ocorre (Aldrighi; Hueb; Aldrighi, 2000; Bortoletto et al., 1999; Souza, 2001).

De qualquer forma, o termo menopausa foi criado em 1816 pelo médico francês Gardanne e rapidamente tornou-se comum no meio médico (Lock, 1998; Greer, 1994).

Etimologicamente encontrei duas definições para o termo climatério, ambas procedentes do grego. Uma é descrita como klimacter, que significa período crítico, expressão originada do latim climaterium, que identifica qualquer época da vida considerada crítica, por se pensar que o organismo humano sofria periodicamente transformações (Biffi, 1991). Outra o define 
como "degrau de escada" e expressa a idéia de uma fase de transição da vida da mulher na qual ela está, supostamente, descendo (Cunha, 1993).

Em contrapartida, consoante a North American Menopause Society (NAMS), a menopausa é definida como um episódio biológico natural e não uma doença causada pela deficiência de estrogênio. Pode ocorrer espontaneamente ou ser induzida por meio de uma intervenção médica, por exemplo: ooforectomia bilateral, quimioterapia e radioterapia pélvica (NAMS, 2000; 2003; Landerdahl, 2002).

Em 2001, o Stages of Reproductive Aging Workshop (STRAW), organizado pela North American Menopause Society (NAMS), propôs a divisão do climatério em estágios: a transição menopausal, que vai dos 37 até 46 anos; a perimenopausa, dos 46 aos 50 anos; a pós-menopausa, dos 51 aos 65 anos e a terceira idade, após os 65 anos de idade. A menopausa ocorre geralmente entre os 48-52 anos. Estas etapas compõem o climatério (NAMS, 2003).

De acordo com o Council of Affiliated Menopause Societies (CAMS) órgão da Internacional Menopause Society (IMS), o climatério descreve a fase da vida da mulher que marca a transição da fase reprodutiva para uma outra não reprodutiva. Mais do que um marco temporal, trata-se de um processo que, algumas vezes, mas não necessariamente sempre, associase a sinais e sintomas específicos, quando então caracteriza a síndrome climatérica. De qualquer forma, é consenso entre os autores que a idade cronológica em que a menopausa ocorre é um pobre indicador do início e do 
fim da transição menopausal (Neco; Sá; Castilho, 1995; Favarato et al., 2000; NAMS, 2000; 2003).

Diante da conceituação do climatério, como um processo dividido em estágios específicos, pode-se afirmar que dentro da ampla faixa etária em que ocorre, muitos são os fenômenos vividos pela mulher, pois abrange a idéia da infertilidade e sensação de não ser mais a jovem com pleno vigor físico, com infinitas possibilidades, incluindo a sensação de envelhecer, que traz consigo os sinais da finitude.

Constata-se então que esta fase crítica da vida da mulher, também chamada de meia-idade feminina, é um estágio importante e complexo que traz numerosas mudanças não só no âmbito físico, como no emocional e social (Banister, 2000).

Resgatando a forma como o "sujeito" vem sendo analisado, no decorrer da história da ciência, percebo que se trata de um sujeito objetificado, nem sempre contextualizado e considerado como um ser complexo, mas como um sujeito-coisificado. Esta constatação fez-me sentir angústia ainda maior. Minhas inquietações aumentaram diante da percepção de que todas as teorias foram levadas a cabo à revelia do sujeito que vivencia os mais diversos processos de vida.

Pode-se constatar que a mulher vive cerca de um terço de sua vida após a menopausa, dado este que suscita reflexões sobre o impacto da longevidade na qualidade de vida desta parcela da população (Jiménez Lopez; Peres Silva, 1999; Aldrighi; Hueb; Aldrighi, 2000; Buchanan; Villagran; Ragan, 2001; NAMS, 2003). 
Importante salientar que o climatério pode também ser chamado de perimenopausa. Ele se inicia na pré-menopausa e termina um ano após a menopausa. Esta é a definição proposta pela Organização Mundial da Saúde (OMS) e diverge da Sociedade Internacional da Menopausa que prolonga a vigência do climatério até a velhice e assinala o fim do período fértil da mulher. A pós-menopausa seria então o período que se segue à menopausa e se prolonga até a velhice, cujo início é impreciso (Bortoletto et al., 1999; Halbe et al., 2002).

Outros autores são categóricos ao afirmarem que estão no climatério todas as mulheres entre 35 e 65 anos de idade e que para seu diagnóstico basta conhecer a idade da mulher (Aldrighi; Hueb; Aldrighi, 2000).

Ressalta-se que fatores genéticos/hereditários; doenças e/ou cirurgias dos ovários; nuliparidade; dieta vegetariana; grandes altitudes; magreza; uso de medicamentos quimioterápicos e o hábito de fumar podem influenciar a ocorrência do climatério. O tabagismo pode antecipar os sintomas em até um ano e meio a dois anos. Os estudos sugerem haver associação de outros fatores com o tempo da ocorrência da menopausa, por exemplo: a multiparidade, o aumento da massa corpórea. Até mesmo a história de melhor desempenho cognitivo na infância pode prolongar o período de maior produção estrogênica. Por outro lado, ainda carece de confirmação científica a relação entre a idade em que a menopausa ocorre e o uso de contraceptivo oral, a idade da menarca, a idade da menopausa da mãe, o status socioeconômico e marital e a raça (Aldrighi; Hueb; Aldrighi, 2000; NAMS, 2000; 2003). 
De qualquer forma, os sinais e sintomas do climatério podem ser classificados cronologicamente, ou seja, os que incidem a curto e longo prazo. Dentre as manifestações iniciais estão a irregularidade menstrual; os sintomas vasomotores (os fogachos, que freqüentemente começam como uma sensação de pressão na cabeça, seguida pela sensação de calor na cabeça, pescoço e tórax; as palpitações e as ondas de calor); as manifestações atróficas no sistema geniturinário: prurido, dispareunia (dor durante o ato sexual); as alterações da pele e fâneros e as alterações psíquicas, que vão da fadiga à depressão. As manifestações tardias são a osteoporose e as doenças cardiovasculares (DCV) (Appolinário et al., 2001; Aldrighi; Hueb; Aldrighi, 2000).

No que se refere à prevalência de sintomas específicos, as pesquisas apontam que o mais característico é o fogacho, presente em cerca de $90 \%$ das mulheres, que está relacionado diretamente com a redução dos hormônios gonadais. Sintomas depressivos, de ansiedade e cognitivos também fazem parte do quadro clínico e são experimentados por cerca de $30 \%$ a $50 \%$ das mulheres que procuram tratamento. A relação dos sintomas psíquicos, com as alterações hormonais, é menos clara do que a existente em relação aos fogachos (Jiménez Lopes; Péres Silva, 1999; Aldrighi; Hueb; Aldrighi, 2000; Velazco Murillo et al., 2000; Appolinário et al., 2001).

Nesse sentido, vários fatores podem estar implicados na gênese dos sintomas psicológicos do climatério e as condições de saúde anteriores da mulher influenciam a sua manifestação nesta fase da vida. Salienta-se, por exemplo, que a ocorrência de transtornos psiquiátricos prévios pode ser um 
fator de risco para o desenvolvimento de sintomas psíquicos após a menopausa, havendo referência, ainda, de que traços da personalidade e características pessoais poderiam influenciar o aparecimento desta sintomatologia (Pinto-Neto et al., 1994; Appolinário et al., 1995; Appolinário, 1999; Appolinário et al., 2001; Scalco, 2002).

Confirmando tal assertiva, destaco um estudo que tratou da percepção dos sintomas da menopausa entre mulheres australianas, antes e após a menopausa. Os resultados mostraram que nem todos os sintomas do climatério, apontados pelas mulheres, são decorrentes da carência estrogênica e que há relação entre as expectativas que se tem da menopausa e as experiências reais vividas neste período. Outro achado foi a relação de sintomas psicológicos sentidos ao longo da vida com os outros eventos reprodutivos experimentados pela mulher. Os autores afirmam, ainda, que há possibilidade de que os sintomas do período pré-menstrual e os da menopausa tenham uma etiologia em comum (Abraham; LlewellynJones; Perz , 1995).

Outro estudo comparativo sobre os sintomas do climatério entre mulheres australianas e japonesas demonstrou que fatores culturais podem influenciar a forma como cada um experiencia as mudanças psicológicas e fisiológicas típicas desta fase do ciclo reprodutivo (Anderson et al., 2004).

Por outro lado, estudo realizado entre mulheres cubanas revelou que, para aquelas que apresentam elevada auto-estima e evidente realização pessoal, o climatério é menos sintomático (Navarro Despaigne; Fontaine Semanat, 2001). 
Os autores afirmam que a etapa climatérica constitui um período de adaptabilidade e conhecimento em relação às mudanças na vida da mulher, que se expressam tanto no âmbito biológico como no social, colocando a mulher numa condição de maior vulnerabilidade nas suas relações interpessoais (Navarro Despaigne; Fontaine Semanat, 2001; Pinto-Neto et al., 1994).

Corroborando com este enfoque, alguns pesquisadores comentam que as manifestações psicológicas muitas vezes decorrem dos tabus sociais que envolvem a menopausa, especialmente pelo reposicionamento da mulher no âmbito familiar com a saída dos filhos de casa e conseqüentemente abstração repentina de suas funções (Aldrighi; Hueb; Aldrighi, 2000).

Estudos antropológicos apontam que o climatério é um evento biocultural e que merece ser apreciado de forma mais abrangente e que a cultura, a condição social, o estilo de vida, enfim, todo o contexto no qual o indivíduo está inserido, deve ser considerado quando pretende refletir-se sobre o processo de transição para o envelhecimento (Lock, 1998; Brown, 1983).

Pode-se perceber que se trata de uma etapa da vida da mulher em que se Ihe apresentam mudanças físicas, psíquicas, sociais e culturais, as quais põem em prova sua capacidade para levar a cabo os ajustes psicológicos e sociais necessários, que permitem manter seu equilíbrio emocional e continuar seu desenvolvimento (Jiménez Lopes; Péres Silva, 1999).

Outro aspecto importante a ser considerado é que a problemática do climatério extrapola o âmbito privado da vida das mulheres que se 
encontram nesta fase do ciclo reprodutivo e alcança a esfera pública quando coloca em evidência os riscos aos quais esta parcela significativa da população está exposta. Assim sendo, considerei oportuno apreciar os aspectos relativos à Saúde Pública tendo em vista que o binômio carência estrogênica e envelhecimento pode acarretar processos patológicos que comprometem a qualidade de vida da população feminina.

\subsubsection{Situando o climatério no âmbito da Saúde Pública}

No âmbito da Saúde Pública, chama a atenção a expectativa de que em 2020 haverá mais de um bilhão de indivíduos acima de 60 anos de idade. Assim sendo, a assistência prestada à mulher climatérica passa a constituir um desafio, já que se sabe que com a prevenção adequada dos riscos típicos desta fase, o nível de saúde e a qualidade dessas mulheres melhorariam consideravelmente (Navarro Despaigne; Fontaine Semanat, 2001; Halbe et al., 2002; Pedro et al., 2002).

Salienta-se o fato de o Brasil ter atualmente uma população de 160 milhões de habitantes, dos quais 56\% são mulheres. Nos últimos 40 anos, a expectativa de vida feminina tem aumentado, passando de 45 anos em 1968 a 68 anos na atualidade. Este dado mostra um incremento de 50\% em apenas 45 anos e as estimativas são de que esse aumento se mantenha durante o século XXI. De qualquer forma, para alguns autores, o período 
etário aceito em que a população poderá apresentar os sintomas do climatério é a partir dos 40 anos (Haines et al., 1995; Buchanan; Villagran; Ragan, 2001; Pedro et al., 2002; NAMS, 2003).

No que se refere ao Estado de São Paulo, 12\% da população é constituída por mulheres nesta idade ou mais. Isto significa que 4.252.745 mulheres paulistas estão sob o risco de experimentar a sintomatologia e os efeitos decorrentes da deficiência estrogênica (Pedro et al., 2002).

Alguns autores enfatizam a necessidade de direcionar a atenção para a saúde da mulher no período pós-menopausal, tendo em vista que o crescimento populacional deste segmento é mais intenso e é nesta fase da vida da mulher que as doenças degenerativas (osteoporose, doença cardiovascular, doença de Alzheimer) são mais incidentes e altamente debilitantes, interferindo na qualidade de vida de forma expressiva (Aldrighi; Hueb; Aldrighi, 2000; Zahar et al., 2001).

A preocupação com a melhoria da qualidade de vida da mulher, durante esta fase, tem levado, de forma crescente em todo mundo, à elaboração de programas que atendam às necessidades de saúde da população feminina durante o climatério, tendo em vista que não se trata apenas de um problema médico, mas também implica aspectos sócioeconômicos que merecem atenção especial dos governos nos seus programas de prevenção de doenças e promoção da saúde (Aldrighi; Hueb; Aldrighi, 2000).

Vale ressaltar que no Brasil, com a criação do Programa de Atenção Integral à Saúde da Mulher (PAISM) em 1983, evocou-se o conceito de 
integralidade na assistência à saúde da mulher, que envolve a oferta de ações globalmente dirigidas ao atendimento das necessidades do grupo em questão. Entretanto, no que diz respeito à assistência à mulher no climatério, percebe-se que os programas e ações específicas voltados para assistir a mulher de meia-idade ficam na dependência de iniciativas individuais e da sensibilidade de cada profissional, não configurando uma ação articulada e organizada dos serviços de saúde, voltada para o atendimento integral (Daoud, 2002).

Nessa perspectiva, chama-se a atenção ainda para o fato de que o PAISM centrou sua ação no aspecto biológico, distanciando-se da visão da mulher como um ser existencial que supera a objetividade alcançando a subjetividade e a intersubjetividade. Houve o esvaziamento do conteúdo essencial do programa e a implementação de ações se restringiu ao âmbito da saúde reprodutiva (Daoud, 2002).

Esta constatação é evidenciada pelos relatos de mulheres que passaram pela experiência de procurar o serviço de saúde e se depararam com profissionais pouco envolvidos com esta área da especialidade, seja no que se refere ao domínio do conhecimento sobre o assunto, seja quanto à sensibilidade aos processos vividos pela mulher neste período da vida (SAND, 1995; Daoud, 2002).

Outros autores enfatizam a necessidade de capacitação e atualização dos profissionais da rede primária de saúde visando ao incremento do diagnóstico e manejo integral do climatério por meio da integração das ciências da saúde com as ciências sociais buscando ampliar a sua 
abordagem (Candella et al., 1995; Stepke, 1998; Velazco Murillo et al., 2000; Navarro Despaigne; Fontaine Semanat, 2001).

A alta taxa de uso de tranqüilizantes pelas mulheres, que consultam o profissional médico para queixas climatéricas, é outro dado importante, que reforça a necessidade de capacitação profissional. Este fato pode indicar, em alguns casos, diagnóstico errôneo em relação aos sintomas psicológicos, sem que tenha havido correlação entre a presença desses sintomas com o estado menopausal. Além do mais, estudos mais recentes não confirmam a idéia de que ocorre maior prevalência de depressão na menopausa (Favarato et al., 2000; Appolinário et al., 2001; Pedro et al., 2002).

Creio que o empenho dos profissionais de saúde, quanto à orientação das mulheres sobre o climatério, assume papel primordial na perspectiva de uma melhor qualidade de vida para as mulheres de meia-idade. Vale lembrar que a interação cliente-profissional da saúde e a influência dos meios de comunicação de massa assumem relevância no que se refere à garantia da informação correta sobre o climatério e, conseqüentemente, à motivação das mulheres para buscar assistência à sua saúde nesta fase da vida (PintoNeto et al., 1994; Velazco Murillo et al., 2000; Buchanan; Villagran; Ragan, 2001; Pedro et al., 2002).

A menopausa é um evento físico que ocorre durante o climatério no corpo da mulher e a maneira como se interpreta este fato pode determinar a forma como a experiência é percebida. A informação que ela recebe sobre a menopausa, ao longo da vida, poderá afetar diretamente sua percepção e 
crença a respeito dos eventos vividos, acrescidos de outros fatores já mencionados, como a auto-estima.

A menopausa é uma passagem silenciosa e, talvez por isso, não tenha a atenção que as demais etapas da vida recebem. Na maioria das vezes, a mulher aprende que seu corpo é algo muito íntimo e que as discussões sobre ele são tão íntimas quanto suas partes. Dessa forma, a mulher atinge a meia idade trazendo consigo tal crença (Buchanan; Villagran; Ragan, 2001).

Sob esta ótica, é interessante destacar o estudo realizado entre mulheres japonesas e chinesas no qual se evidenciou que a maioria desconhecia os efeitos do climatério, tinha uma boa referência sobre esta fase da vida e o relato dos sinais e sintomas típicos foram menos incidentes. Em tais grupos, no que se refere à fonte de informação sobre este período da vida, estava restrita à família e amigos, ficando a escola e os serviços de saúde como últimos recursos. Este achado é preocupante quando se avalia os benefícios do acesso às terapias específicas para as complicações do climatério, uma vez que a longevidade feminina também é objeto de atenção da saúde pública, principalmente em países com características demográficas tão específicas como a China e o Japão (Haines et al., 1995).

Outro estudo realizado no México revelou que o tipo de informação que as mulheres diziam possuir era produto da informação comercial, mais do que resultado de ações educativas em saúde por parte das instituições (Velazco Murillo, 2000). 
A configuração da situação de falta de conhecimento sobre esta fase do ciclo reprodutivo, por parte da população, indica a necessidade de estudos que determinem o nível de conhecimento e atitudes da mulher climatérica, visando ao planejamento de estratégias educativas destinadas a incentivar a procura pela atenção médica, tendo como objetivo principal a redução da morbimortalidade associada à Síndrome Climatérica e à etapa pós-menopausica (Velazco Murillo, 2000).

No que diz respeito à abordagem feita sobre o climatério, percebe-se que a ênfase dada aos aspectos fisiológicos parte não apenas dos profissionais, como também das mulheres que procuram os serviços de saúde. Fato este que pode ser observado num estudo realizado num município do Estado de São Paulo, com 456 mulheres, na faixa etária dos 45 aos 60 anos, cujos resultados revelaram que as principais queixas foram: irregularidade menstrual, sintomas "típicos" do climatério (não especificados no artigo) e sintomas urogenitais, respectivamente (Pedro et al., 2002).

Dentre os achados, ressalta-se que a maior intensidade dos sintomas psicológicos e o fato de estar usando Terapia de Reposição Hormonal (TRH) correlacionaram-se à maior procura pelo serviço de saúde. Em contrapartida, para as mulheres que não procuraram assistência, assim o fizeram por acharem que os sintomas do climatério não merecem atenção médica. Este fato sugere que a "menopausa" é tida como uma ocorrência esperada e que neste processo só se deve intervir se os desconfortos forem maiores (Pedro et al., 2002). 
Importante acrescentar a forma como a TRH é apresentada. Trata-se de uma panacéia para tratar a doença da deficiência estrogênica, seja na prevenção das doenças cardiovasculares, seja da osteoporose. Nesse sentido, a promessa da eterna beleza e feminilidade e da menopausa livre dos sintomas, a fuga dos riscos das doenças crônicas, apenas reforçam a ideologia médica de que a menopausa é uma doença que requer intervenção hormonal. Percebe-se, portanto, que na maioria das vezes, quando as mulheres recebem alguma assistência médica nesta fase da vida, esta restringe-se ao aspecto biológico, indicando que as mulheres são identificadas primeiramente sob o aspecto sexual-reprodutivo. É como se o climatério fosse uma profecia autocumprida a respeito do que uma mulher deve sentir na sociedade ocidental, considerando-se as expectativas em relação aos sistemas de saúde que estão disponíveis (Stepke, 1998; Buchanan; Villagran; Ragan, 2001).

Ainda, com respeito à TRH, a discussão sobre a sua adoção deve considerar o aspecto ético-profissional e os interesses alheios das indústrias farmacêuticas no que se refere à movimentação de cifras tão significativas (Greer, 1994).

Assim, torna-se imperativo buscar a ampliação da assistência a ser prestada às mulheres, considerando que o climatério abarca aspectos mais abrangentes e complementares do que aqueles usualmente enfatizados pelos profissionais e/ou programas de saúde. Salienta-se que, tanto na área da assistência, como na academia, o modelo praticado e ensinado, no cuidado à mulher nas diferentes fases da sua vida, muitas vezes reproduz o 
modelo biologicista e isto garante a manutenção de uma forma de cuidar que já não corresponde às expectativas da clientela.

Ressalta-se ainda que não se pode desconsiderar a incidência de doenças cardiovasculares e as conseqüências da osteoporose, pois são problemas sérios e tipicamente biológicos que merecem atenção especial por comprometerem a qualidade de vida das mulheres. Dessa forma, o acesso às ações preventivas e ao tratamento destas complicações deve ser organizado e garantido.

No que diz respeito à ampliação do enfoque dado ao climatério, tanto do ponto de vista biológico como da perspectiva sóciocultural, devemos considerar que existem períodos de transformações mais aceleradas em que a transição assume caráter de crise e adquire certa radicalidade que a converte em possibilidade de crescimento ou retrocesso, oportunidade ou ameaça. Quase todas as culturas aceitam a existência de crises normais quando se alcança a maturidade sexual. A vivência do climatério também pode ser vista como uma experiência que contribui para a consolidação da existência do ser. Em vez de ser vista como o fim, esta fase da vida da mulher oferece a possibilidade de aprendizado de um novo ritmo, um tempo para experienciar o processo de amadurecimento do corpo (Sand, 1995; Stepke, 1998; Rousseau, 1998; Banister, 2000).

Sendo assim, buscando entender o climatério como um processo complexo de mudanças, que extrapola os limites da fisiologia, proponho a apreciação de outros aspectos também relevantes na contextualização deste evento que possibilite refletir sobre a temática. 


\subsubsection{Contextualizando o climatério: justificando o tema do estudo}

Os significados sociais atribuídos aos eventos do cotidiano fazem com que o indivíduo desenvolva determinada postura e experimente uma vivência particular dos fenômenos, baseadas na história pessoal e na sociedade/contexto em que se encontra inserido.

A etapa climatérica, por sua vez, constitui um período de adaptabilidade em relação às mudanças na vida da mulher, que se expressa tanto biológica como socialmente e, geralmente, durante este processo, a mulher se torna mais vulnerável e susceptível a problemas nas relações interpessoais que mantém. Diante da diversidade de possibilidades de viver este processo, as características do sistema social predominante no ambiente onde está inserida influenciam a forma como, social e clinicamente, a mulher expressará o climatério (Stepke, 1998; Banister, 2000; Navarro Despaigne; Fontaine Semanat, 2001).

Interessante observar que na maioria das sociedades ocidentais, em que a beleza física e a juventude são extremamente enfatizadas, a incidência de sintomas relacionados ao climatério é alta. Já em algumas culturas não ocidentais, como exemplo, na casta Rajput da Índia, o status das mulheres se eleva na pós-menopausa, pois nessa etapa de suas vidas elas podem socializar-se livremente e participar das atividades que antes Ihes eram proibidas (Pinto-Neto et al., 1994; Appolinário et al., 1995; Candella et al., 1995). 
Num passado longínquo, com o objetivo de explicar e entender a natureza feminina, durante séculos, muitas idéias perpassavam as concepções sobre o corpo feminino. Essas idéias, que concebiam os órgãos genitais femininos como algo com manifestações sobrenaturais, transformavam a menstruação em substância temida que, ao emergir do útero, poderia contaminar, envenenar, conspurcar. Com o passar do tempo, a menarca passou a indicar o marco do início da vida da mulher e a menopausa o seu fim (Vieira, 2002).

Por outro lado, na atualidade, outros autores comentam que a parada das menstruações resulta em múltiplos significados para a mulher, o que gera simultaneamente sensação de alívio e apreensão. O fim das restrições, constrangimentos, desconforto e preocupações, principalmente com a fertilidade, se contrapõem com receio, consciente ou não, de perda da feminilidade, do valor social e da saúde (Penteado et al., 2000).

Parece, enfim, que no climatério a mulher perde todos os atributos recebidos durante a puberdade, tais como beleza, vigor, fertilidade; portanto, se ela tiver colocado toda sua auto-estima exclusivamente na sua capacidade de conceber e na beleza de seu corpo, sentir-se-á desvalorizada e não encontrará sentido em sua vida (Jiménez López; Peres Silva, 1999; Cousins; Edwards, 2002).

Assim, torna-se imprescindível buscarmos apreciar a definição dos períodos críticos da vida (climatérios) proposta por Greer (1994). A autora afirma que a vida da mulher é feita de mudanças tão nítidas que poderiam perfeitamente ser chamadas de metamorfoses. Com freqüência, estas 
mudanças: de criança a mulher, de amante a esposa, de mãe a avó, são exteriorizadas por estados físicos contrastantes: da magricela a curvilínea, ou grávida e obesa, a magricela novamente. A maioria das mudanças biológicas subjacentes deve ser escondida ou negada. Só na mudança de solteira para casada, que paradoxalmente talvez não envolva nenhuma alteração fundamental no estilo de vida ou no status biológico, há um sinal externo, um cerimonial até exagerado - a mudança do nome da mulher.

A autora propõe fases ou passagens específicas da vida da mulher, que começam com a primeira fase crítica, que é o nascimento e a primeira infância; a segunda passagem tempestuosa é a adolescência; a terceira, a defloração; a quarta, o parto e a quinta, a menopausa. Entre elas situam-se fases relativamente calmas: a segunda infância, o tempo de solteira, o tempo de casada e o tempo da maternidade. O quinto climatério (durante o qual a menopausa ocorre) é superado em importância somente pelo grandioso climatério que é a morte. [...] O climatério não é um rito de passagem, mas a passagem em si (Greer, 1994, p. 48).

Para esta autora, a menopausa, por ser um não-evento, isto é, o período menstrual que não vem, nem pode ser transformada em rito. Ela pode sim ser percebida de forma variada por cada uma das mulheres (Greer, 1994).

Banister (2000) cita que na cultura ocidental, os aspectos positivos da meia-idade não são considerados como em outras culturas nas quais a mulher madura tem acrescido o valor do seu papel social e este reconhecimento serve de guia para que siga a sua trajetória para a 
maturidade. Salienta ainda o atual envolvimento das mulheres no mercado de trabalho que exige maior controle sobre suas condições físicas, colocando-as numa situação de conflito entre as exigências do seu papel social e sua capacidade orgânica para tal.

Verificou-se, em alguns estudos, que a forma como a mulher identifica a menopausa varia conforme a etapa do ciclo reprodutivo em que se encontra. Para as mulheres que estão entre a faixa etária dos 40 aos 50 anos, as preocupações são relativas à cessação das menstruações e à perda da capacidade de cumprir com seu papel social na reprodução; dos 50 aos 60 anos, aparecem sentimentos de desesperança, perda dos atributos da feminilidade e libido; com 60 anos predomina a idéia da incapacidade de ser mulher e a sensação de mutilação, já que a menstruação lhe outorga o título de mulher e quando ela se vai é como se houvesse perdido uma parte de si mesma (Appolinário, 1999; Favarato et al., 2000; Pelcastre-Villafuerte; Garrido-Latorre, 2001).

Há alguns anos, a menopausa era considerada como um marco dramático do declínio da sexualidade e da feminilidade e o climatério representava a castração da mulher em função de que se acreditava que os baixos níveis estrínicos estavam associados à ausência da libido e à incapacidade sexual. Atualmente, já se sabe que o hipoestrogenismo é responsável por alguns distúrbios sexuais e mais importante que as modificações físicas advindas pela idade são os fatores psicológicos e biológicos que acompanham a menopausa (Abdo et al., 1997; Bortoletto et al., 1999). 
Os estudos ainda evidenciam que as modificações promovidas pelo climatério, na esfera sexual, são: diminuição da resposta sexual, dispareunia, diminuição da atividade sexual e disfunções do parceiro. Entre as principais queixas de mulheres de 52 a 62 anos de idade destaca-se o ressecamento vaginal, que se traduz pela dispareunia, que pode ser explicada pela diminuição da produção e do volume da secreção vaginal, além da perda da elasticidade da vagina (Abdo et al., 1997; Bortoletto et al., 1999; Favarato et al., 2000).

Sabe-se que uma variedade de fatores correlaciona-se com a diminuição do desejo sexual. Os fatores psicossociais e aqueles próprios do envelhecimento, como o aparecimento de doenças crônicas e degenerativas; estresse decorrente de adoecimento ou morte de pessoas próximas, influenciam diretamente a satisfação das necessidades sexuais (Favarato et al., 2000; Penteado et al., 2000).

Neste emaranhado de situações entram em jogo os aspectos pessoal e interpessoal como também o balanço do que foi conquistado durante a vida e o que ainda será. Então, a visão que a mulher tem do climatério irá determinar a maneira como enfrentará os próximos anos (Lima et al., 2002).

No que se refere à relação familiar, em estudos realizados com um grupo de mulheres pós-menopausadas, encontrou-se que essas mulheres sentem-se como um peso para sua família. Este achado é muito importante quando se retoma a questão do valor que a família tem para o equilíbrio emocional-afetivo dos indivíduos. O que se percebe geralmente é que a mulher sente a necessidade de buscar alguém que a auxilie a enfrentar os 
seus problemas, que ouça suas angústias e dúvidas. Ao mesmo tempo, ela expressa sua angústia por ter atingido na meia-idade e sente dificuldades para encontrar o que buscam (Lugones Botell; Valdes Sánchez; Pérez Piñero, 1999; Daoud, 2002).

Enfim, quais seriam as angústias e dúvidas? O que é que se busca? Questões como estas remetem-me ao fato de que em uma sociedade em que se valoriza a juventude e o vigor físico e na qual a mulher tem maior valor social quando possui capacidade de gerar filhos, não se pode esperar que haja resposta favorável às mudanças trazidas pelo climatério, pois se tudo que a sociedade valoriza perde-se nesta etapa da vida.

Por outro lado, a idéia de doença que permeia a menopausa faz com que as mulheres tenham uma idéia equivocada a respeito do fato e percebam esta fase como uma transição vital desfavorável. Dessa forma, o conceito de climatério parece ser ambíguo e a pouca informação sobre o assunto afeta a percepção que as mulheres têm quanto à experiência da menopausa (Velazco Murillo et al., 2000; Buchanan; Villagran; Ragan, 2001).

Assim como a menarca, a menopausa é experienciada individual e subjetivamente pela mulher. Neste sentido, os profissionais de saúde devem atender as necessidades da clientela baseando-se em cada caso, avaliando os sinais e sintomas associados com a menopausa, levando em conta a complexidade que compreende a totalidade do indivíduo (Buchanan; Villagran; Ragan, 2001).

Todas essas questões, ou seja, contradições entre as intenções e a efetivação de um atendimento integral à mulher durante o climatério, podem 
encontrar explicações na tendência predominante de ver esta fase da vida como doença. O caráter de transição biográfica se vê reduzido pela terminologia que fala de "sintomas" do climatério. Esta construção médica leva a supor que a "condição" deve ser "tratada" e se há sintomas, estes devem ter causa que, freqüentemente, se agrupam em três grandes categorias: redução de estrogênio; fatores socioculturais e fatores da personalidade. $\mathrm{O}$ valor dado a cada um deles vai determinar o tipo de intervenção (Stepke, 1998).

Nesse caso, corre-se o risco de o resultado das intervenções ser considerado bem sucedido somente pelos que a administram, porém insuficiente pelos usuários e público, o que me leva a supor que alguns profissionais podem subestimar novos pontos de vista sobre suas práticas ou as demandas que sua profissão não consegue atender. Isto significa que, às vezes, as necessidades dos usuários não são adequadamente interpretadas, pois a resposta do sistema profissional atende a seus próprios critérios sem, muitas vezes, levar em conta o que os usuários precisam (Stepke, 1998; Banister, 2000).

Stepke (1998) chama a atenção também para o fato de que nem sempre os envolvidos, de um lado os usuários e de outro o profissional, reconhecem a problemática apresentada. $\mathrm{O}$ autor enfatiza a exigência de entendermos que o importante não é simplesmente "saber" algo e sim "saber-fazer" algo, ou seja, responder às demandas dos clientes, pois nem a simples expressão de uma necessidade, nem a pura disposição de um saber 
asseguram o bem-estar e a satisfação das pessoas envolvidas no processo de cuidar.

Goldfarb (1998) comenta que o sujeito é produto de um encontro, de uma articulação entre a interioridade e exterioridade e que esta articulação não é apenas fundante da subjetividade, mas que também constitui o campo onde se encontram os objetos de sua satisfação. Neste contexto, a violência exercida pelo discurso da exaltação da juventude e da produtividade propõe um modelo que anula a condição do Ser e seus direitos de cidadania. Portanto, a consciência da própria deterioração pode pôr fim à onipotência, e o Ser, despojado da beleza, da saúde e da sua condição de produtor de bens e de reprodutor da vida, assiste o declínio do seu corpo e perde a fantasia de imutabilidade e imortalidade.

Para iniciar uma reflexão sobre a fase da meia-idade vivenciada pela mulher, o climatério, optei por apreciá-lo, não mais como um processo de vida de um sujeito, mas como um fenômeno que poderá se desvelar à medida que for interrogado. Interrogar o fenômeno do climatério poderá satisfazer minha ânsia de compreender a sua vivência sob a ótica dos sujeitos que o experiencia.

Com estes argumentos apresento a abordagem metodológica escolhida para a condução desta pesquisa. 
Escolhendo a abordagem metodológica 


\section{ESCOLHENDO A ABORDAGEM METODOLÓGICA}

Compreender pressupõe apreciar com cautela, buscando as minúcias, o detalhe, a subjetividade do objeto. Para Capalbo (1994 a; b; 2002), os enunciados têm um significado e na existência do mundo só podemos conhecer e compreender aquilo que é vivido. Baseada nessa afirmação, o caminho escolhido para percorrer este estudo perpassa pelo neopositivismo, o qual defende que para haver ciência basta ocorrer verificação sem necessidade de comprovação, visto que o fenômeno do vivido humano tem uma estrutura significativa construída pelos homens em seu mundo vivido.

Assim sendo, como enfermeira que atua na área da Saúde da Mulher, optei pelo caminho da pesquisa qualitativa e assim o fiz por entender que nesta trajetória poderia encontrar-me enquanto ser que vivencia um processo existencial, ao mesmo tempo em que partilha seus anseios com os que se relaciona no dia-a-dia vivenciando a enfermagem.

Com este intuito, por meio da pesquisa de abordagem qualitativa, encontrei o respaldo necessário para a compreensão daquilo que desejo estudar. Tal abordagem não se preocupa com generalizações, princípios e leis. O foco da atenção é centralizado no específico, no peculiar, no individual, almejando a compreensão e não a explicação dos fenômenos estudados (Capalbo, 1994a; Martins; Bicudo, 1989).

Dentro desse contexto, escolhi o enfoque fenomenológico por acreditar que este abarca o existir humano em sua totalidade e por isso oferece a 
oportunidade de interpretação da experiência vivida. Optei pela fenomenologia para subsidiar o meu caminho de olhar, primeiramente a mim mesma e posteriormente o mundo a começar da minha própria intencionalidade.

A escolha do referencial teórico-metodológico exige, primeiramente, uma postura ideológico-filosófica definida do pesquisador diante do que se deseja estudar, mesmo porque, no caso das investigações que têm como objetivo compreender fenômenos vividos, experiências de vida, a escolha do referencial apropriado assegura o rigor e possibilita o cumprimento do intento.

A pesquisa que me propus realizar não encontrou caminhos pelo método exclusivamente racional, pois, estudar a vivência de processos existenciais humanos exige algo mais do que quantificar. Exige a articulação de um saber mais complexo do que a pura soma de dados, cujo resultado pressupõe a busca da verdade e, como ressaltam Capalbo (1994 a) e Martins; Bicudo (1989), quanto mais verdades mais possibilidades de se encontrar inverdades.

Nesse sentido, a pesquisa de abordagem qualitativa solicita ao pesquisador colocar em prática o conceito de inseparabilidade, o que o remete a um mundo extraordinariamente novo e a uma inusitada atitude de estar-no-mundo. Trata-se da ampliação e do aprofundamento do olhar visto que a visão que se tem do mundo modela e define nossa ação-no-mundo. É a chamada cosmovisão, que não é meramente uma representação mental ou tentativa racional de apreensão da realidade, mas implica uma 
redefinição atitudinal global, uma efetiva mudança no nosso modo de conduta de estar-no-mundo. É uma atitude holocentrada de uma pessoa que a define como um ser humano que busca restabelecer-se como Ser (Crema, 1995).

Dessa forma, a percepção dos homens em relação ao mundo-vida encontra-se envolvida em um mundo de possibilidades, no qual estes são rodeados por muitos modos de estar-no-mundo, perplexos por estarem sempre diante de um novo olhar, de um novo saber que também nasce de dentro de si, do próprio Ser.

Assim sendo, a minha opção pelo método fenomenológico foi motivada pela minha afinidade entre a sua epistemologia e o fenômeno que pretendo estudar, assim como a minha própria visão de mundo enquanto pessoa e pesquisadora. Aproximei-me da fenomenologia buscando compreender a experiência da mulher que vivencia o climatério, cuja essência é passível de ser descrita somente por ela que é quem o vivencia.

Torna-se, portanto, imprescindível discorrer sobre a fenomenologia, abordagem teórico-fenomenológica que iluminou as indagações aqui explicitadas e serviu como ancoradouro onde o pensamento e a razão subjetivados encontraram lugar. 


\subsection{A fenomenologia}

No decorrer dos capítulos anteriores tentei fazer pequenas incursões na literatura a fim de trazer à tona alguns aspectos que pudessem auxiliar na compreensão desta fase da vida da mulher. Esse breve encontro com os autores mostrou-me que o climatério tem aspectos relativos ao corpo, modificações e transformações, aspectos sociais, políticos e culturais. No entanto, não pretendi tratar esta temática numa visão naturalística de causa e efeito e, sim, numa visão existencial, na qual o Ser se mostra em sua essencialidade, conforme sua experiência de vida.

Para isso, foi importante que o conteúdo aqui explicitado fosse colocado de lado, temporariamente, para, então, ser retomado a posteriori, não como fio condutor de análise, mas como um coadjuvante à análise e interpretação dos significados emergidos dos dados coletados. Trata-se de assumir uma atitude fenomenológica (Dartigues, 1992).

A fenomenologia é o estudo ou a ciência do fenômeno. Seu domínio é ilimitado e não se pode confiná-la numa ciência particular. Nasceu de uma consciência de crise da cultura, do conhecimento e da própria filosofia e do confronto às insuficiências metodológicas da ciência positivista que não conseguiam responder à questão: o que dizer do sujeito concreto, em sua vida psíquica imediata e em seu engajamento histórico, que o pensamento objetivo não consegue explicar? (Dartigues, 1992; Josgrilberg, 2000). 
A fenomenologia existencial busca compreender o homem em sua estrutura universal e em sua totalidade existencial complexa, enquanto homem que vive numa dada sociedade histórico-cultural situada, em sentido de carne e espírito, mas sem perder o vínculo com a sua experiência concreta do vivido (Capalbo, 1994a; Pokladek, 2002).

$\mathrm{Na}$ fenomenologia, o método nos conduz a ver o que simplesmente se mostra obscuro, oculto e do avesso, e esse interrogar fundamenta-se na compreensão das relações que buscamos pôr em "descoberto", e não simplesmente na explicação casuística dos fatos estudados. Assim, os fenômenos são observados, aproximados, quantas vezes se fizerem necessárias, em todos os sentidos, "andando em volta de" (Pokladek, 2002).

A tarefa da fenomenologia será mostrar como o outro, o mundo social, cultural, histórico e natural, ao invés de serem fatos já constituídos para um sujeito, ao contrário, são constituídos pelo sujeito. Os "fatos sociais" não são "dados" objetivos, mas são "constituídos" pelos atos da consciência do sujeito transcendental e dessa forma, um dos seus atos é o de preencher e doar sentido. Pode-se afirmar que o sujeito constitui-se por si e para si mesmo como Ser de sentido de si para si e, em seguida, de sentido das coisas (Capalbo, 1994a; Josgrilberg, 2000; Pokladek, 2002).

Diante dessa interpretação pode-se afirmar que o sentido da existência, a razão de ser da vida humana, o amor, a angústia, o desespero, a felicidade, a autenticidade e o acolhimento devem merecer uma meditação filosófica de natureza compreensiva e interpretativa, pois a dimensão subjetiva é preponderante à objetiva e não se pode converter o homem em 
objeto do nosso manuseio, controle e dominação. A ênfase dada nesta perspectiva é encontrada na fenomenologia a partir do seu movimento contemporâneo com Edmund Husserl (Capalbo, 1994a).

Nesse particular, faz-se necessário compreender que se os fenômenos se dão a nós por meio dos sentidos, eles se dão sempre como dotados de uma essência. Esta essência pode ser percebida por transparência. Assim, se todo o fenômeno tem uma essência, isto significa que não se pode reduzi-lo a uma única dimensão de fato, pois por meio de um fato é sempre visado um sentido (Dartigues, 1992).

Para Husserl, o conteúdo inteligível do ser dos fenômenos, em seu aspecto essencial, é captado por uma visão imediata ou "intuição da essência". Essência é um conjunto de significados que é compreendido porque é vivido na existência humana concreta. Então, a intuição da essência distingue-se da percepção do fato. É a visão do sentido ideal que atribui-se ao fato materialmente percebido e é isto que nos permite identificálo (Dartigues, 1992; Capalbo, 1994b).

Por outro lado, chama-se a atenção para a definição de essência como sendo o ser da coisa ou da qualidade que atribuímos à coisa. As essências constituem-se como a armadura inteligível do Ser, são a racionalidade imanente do Ser, o sentido a priori no qual faz parte todo o mundo real ou possível e fora do qual nada pode se produzir. Neste contexto a fenomenologia coloca-se como um método de investigação do concreto e os conceitos que ela utiliza estão sempre afetados de valor compreensivo. $\mathrm{O}$ método fenomenológico é intuitivo e realiza a visada imediata das coisas 
nelas mesmas e nesta visada imediata oferece a possibilidade da apreensão das qualidades sensíveis (cores, som, etc.) e das significações (essências inteligíveis) (Dartigues, 1992; Capalbo, 1994b).

Trata-se então de uma ciência descritiva, rigorosa, concreta, que mostra e explicita o Ser nele mesmo, que se preocupa com a essência (Eidos) do vivido. Ela se apresenta como uma ciência eidética material, pois os vividos intencionais dão forma aos conteúdos de significação (intenção significativa) e ao ato de preenchimento significativo do objeto conhecido (Capalbo, 1998).

Vale acrescentar que a intencionalidade é o ato de atribuir um sentido. É ela que unifica a consciência e o objeto, o sujeito e o mundo. Com a intencionalidade há o reconhecimento de que o mundo não é pura exterioridade e o sujeito não é pura interioridade, mas a saída de si para um mundo que tem uma significação para ele (Forghieri, 1993).

O princípio da intencionalidade é que a consciência é sempre "consciência de alguma coisa", que ela só é consciência estando dirigida a um objeto. Por sua vez, o objeto só pode ser definido em sua relação à sua consciência. Ele é sempre "objeto-para-um-sujeito". É o que se chama de existência intencional do objeto na consciência, uma vez que o mesmo só tem seu sentido de objeto para uma consciência. Sua essência é sempre obtida por meio de uma visada de significação e sem essa visada não se poderia falar de objeto, nem de uma essência de objeto (Capalbo, 1998).

Para esta tomada de consciência da essência como significação, Husserl propôs a suspensão de todos os a priori, de todas as objetivações, 
de todas as afirmações e posições, de todos os pré-julgamentos e posições adquiridas, de todas as amarras que trazemos ao longo da nossa realidade vivida no tempo histórico cultural (Capalbo, 2002).

Cabe lembrar que, metodologicamente, a fenomenologia objetiva mostrar e descrever os fenômenos com rigor negando-se a ser meramente demonstrativa ou reconstrutivista dos mesmos. O que interessa para Husserl não são os fatos ou suas causas, que são objetos da ciência, mas a compreensão das significações essenciais, ou seja, o ato intencional que atribui sentido às coisas e isso se faz pela intuição. Para este fenomenólogo é pela intuição que se dá o preenchimento de uma significação vazia de sentido. Ele se afasta da idéia de que a essência encontra-se numa realidade empírica em estado potencial e afirma que ela é fruto de uma abstração intelectual (Capalbo, 1998).

Os dados obtidos pela pesquisa devem ser correlacionados com o modo como se dão, se mostram e como são vistos já que se entende que o sujeito está ligado intencionalmente ao mundo e qualquer ciência formal, empírica ou interpretativa não pode se organizar à parte deste vínculo (Josgrilberg, 2000).

O estudo da correlação sujeito-objeto consistirá numa análise descritiva do campo de consciência, o que conduziu Husserl a definir a fenomenologia como a ciência descritiva das essências da consciência e de seus atos (Dartigues, 1992). Dessa forma, a experiência da consciência é experiência de algo que não é consciência. O conteúdo inteligente é do objeto e não da 
consciência. A consciência só vai às coisas mesmas e aí doa sentido e estabelece seu campo próprio de visar objetos (Josgrilberg, 2000, p. 79).

Para este autor, a contribuição do método fenomenológico não significa a exclusão de dados factuais, mas consiste na asserção de que toda a ciência, em especial as que tratam do ser humano, possuem o fundo de uma experiência prévia que dá sentido. A fenomenologia oferece a possibilidade de elucidação do comportamento humano enquanto modo originário de ser no mundo, já que seu objetivo primeiro é o de compreender o ser humano enquanto ser histórico, social, psíquico, temporal, espacial, corporal, natural, artístico, falante.

Pode-se afirmar então, que a fenomenologia é a filosofia que propõe a compreensão do homem e do mundo a partir de sua facticidade. É uma volta ao mundo da experiência, do vivido*. É olhar as coisas como elas manifestam-se para apreender-se a essência do fenômeno. Por facticidade entende-se aquilo que é. É o próprio fato, o fenômeno. É o caráter próprio da condição humana, pela qual cada homem se encontra comprometido com uma situação não escolhida (Merleau-Ponty, 1999).

Antes de descrever a trajetória que percorri para chegar à essência do fenômeno, apresentarei alguns pressupostos teóricos da fenomenologia existencial de Maurice Merleau-Ponty, os quais julguei necessários e pertinentes para compreender a vivência do climatério.

Optei seguir os ensinamentos deste fenomenólogo porque o mesmo elucida em suas obras questões concernentes à existência do homem, que

\footnotetext{
*Entender-se-á como vivido o percurso da experiência; como vivência a própria experiência e vivenciada o que já foi experienciado.
} 
poderão, de certa maneira, fundamentar a análise compreensiva e interpretativa dos achados deste estudo. Temas como corpo, mundo, espaço, tempo e liberdade são trabalhados por Merleau-Ponty e, por sua vez, inerentes à experiência existencial.

\subsection{Falando sobre o referencial filosófico de Maurice Merleau-Ponty: o corpo visto com as lentes da fenomenologia}

A opção pelo referencial filosófico de Maurice Merleau-Ponty, para subsidiar a análise dos dados do presente estudo, deu-se no momento em que percebi que a necessidade de aprofundar o conhecimento sobre a temática do climatério vinha ao encontro de questões que perpassavam a esfera profissional e abarcavam a minha própria existência enquanto mulher, cliente em potencial que recebe cuidados e que também está envolvida no cuidar de outras mulheres.

Percebi que para desvelar o fenômeno da vivência do climatério seria necessário o respaldo de uma fundamentação teórico-filosófica que iluminasse a descoberta do ser mulher e as suas percepções sobre a experiência vivida "em" seu corpo durante esta fase do ciclo reprodutivo. Fase esta na qual, usualmente, encontra-se implícita a decadência dos atributos do corpo belo e saudável, entremeada de sensações físicas desconfortáveis. Nesta etapa da sua vida a mulher poderá perceber-se 
vivendo uma experiência inevitável e que, embora seja universal, é vivida solitariamente.

Para compreender a vivência do climatério, caminhei entre as idéias de Maurice Meleau-Ponty, explicitadas na sua obra denominada "A Fenomenologia da Percepção", na qual o filósofo reforça a necessidade da revisão dos conceitos sobre o corpo e a alma, separados por Descartes, e afirma que não há dicotomia entre o homem (corpo e alma) e o mundo e sim infinitas possibilidades de comunhão entre eles (Freitas, 1999).

Para Merleau-Ponty (1999) o corpo não é objeto, mas uma teia de funções ligadas à comunicação, visão, motricidade, sexualidade, emoção. Ele é o instrumento por meio do qual o homem expressa a compreensão em relação ao mundo percebido. Mundo este que, uma vez visado, revela múltiplas possibilidades de interpretação.

O corpo é considerado como um objeto cuja história é resultado das relações que ele mantém com o mundo objetivo. O corpo, portanto, é um objeto do mundo que tem sua origem no coração da experiência vivida. Então, o filósofo afirma: "Eu não tenho um corpo. Eu sou o meu corpo". E é neste corpo que o significado do vivido se manifesta e é por meio deste corpo que compreendo o outro, assim como também é por meio dele que percebo "coisas" (Merleau-Ponty, 1999; Pokladek, 2002).

Pode-se afirmar que o homem percebe o mundo por meio da corporeidade e o faz a partir das suas circunstâncias, do seu viver na sua facticidade (Pokladek, 2002). 
O corpo é o veículo do ser no mundo, é o pivô do mundo e deve ser apreendido não apenas com base em uma experiência, mas sob o aspecto da generalidade e como um ser impessoal, pois, em torno do mundo humano, que cada um de nós se faz, aparece um mundo em geral, ao qual é preciso pertencer em primeiro lugar para depois poder encerrar-se no ambiente particular (Merleau-Ponty, 1999).

Da mesma maneira, a experiência do climatério é generalizada por abranger o mundo feminino, mas trata-se de um processo vivido no âmbito da individualidade.

Passo a perceber o corpo inserido no mundo experienciando vivências no presente, considerando o horizonte de passado e de futuro. Este corpo deve ser reaprendido a cada momento, pois a união da alma e o corpo se realiza a cada instante no movimento da existência e é esta a dimensão que não pode ser perdida. Além disso, Merleau-Ponty aponta a possibilidade de que "[...] haverá sempre sentidos onde houver carne e, onde houver carne há história vivida, única e intransferível [...]" (Pokladek, 2002, p. 18).

É preciso compreender o corpo como um objeto sensível a todos os outros, porque ele ressoa para todos os sons, vibra para todas as cores e é pela percepção que os sentidos se comunicam num sistema sinérgico que possibilita a compreensão e o significado do Ser no mundo (Merleau-Ponty, 1999).

Vale ressaltar que no dia-a-dia das experiências vividas, o corpo age num movimento rotineiro do agir/fazer, das atividades, enfim. Então, é provável que não se consiga racionalizar cada um destes movimentos 
mesmo por que o indivíduo pode responder de maneira automática aos estímulos do cotidiano, sem perceber o significado dos seus movimentos.

Noto que a vivência das alterações corporais durante o climatério traz à tona a sensação de finitude e à medida que a mulher vai tomando consciência disto pode passar a viver os processos de forma isolada e solitariamente, sem perceber a relação deste evento com todos os outros processos existenciais que apontam para o início, o meio e o fim de todas as coisas. É necessário ter consciência de todo o movimento.

Entender a relação entre movimento e consciência do movimento pode facilitar a compreensão do modo de ser, pensar e agir de um sujeito visto que os sentidos e o corpo próprio apresentam o mistério de um conjunto que, sem abandonar sua particularidade, emite, para além de si mesmo, significações capazes de fornecer sua armação a toda uma série de pensamentos e de experiências (Merleau-Ponty, 1999).

Creio estar no caminho certo, pois este trabalho tratou da compreensão da experiência vivida por um Ser e o que se propôs foi o desvelamento de um fenômeno que ocorre no corpo da mulher durante a sua ação no mundo, por meio de movimentos conscientes, num determinado tempo e lugar. Conforme afirma Merleau-Ponty (1999); o sujeito vive as experiências com seu corpo e por meio dele age no mundo e o limite do meu corpo não se restringe a pele, mas vai além das sensações; porque não se trata de uma reunião de órgãos justapostos, divisível, mas de diferentes partes que se relacionam umas às outras, sendo que a posição de cada um dos membros torna-se conhecida por meio do esquema corporal, constituindo-se dessa 
forma o corpo próprio, o Ser. É o viver, o sentir e o ser dando vida à existência.

Cabe salientar que, na visão de Merleau-Ponty (1999), o esquema corporal é a expressão do corpo por meio da relação mútua entre seus membros e suas partes no mundo, isto é, o corpo manifesta-se como presente, deslocando-se no espaço e no tempo, mantendo uma relação de equilíbrio e harmonia com o ambiente.

Por outro lado, devemos atentar para o fato de que o espaço não é o ambiente físico, mas deve ser entendido como um espaço existencial, que reflete como o homem vive sua existência e como ele estabelece essa relação, uma vez que ser corpo é estar atado no mundo, e o nosso corpo não está no espaço, ele é no espaço (Merleau-Ponty, 1999).

A percepção do espaço não é um estado de consciência ou de ato. Exprime a vida do sujeito, a energia com a qual ele tende para um futuro por meio de seu corpo e de seu mundo, é o corpo envolvendo os objetos em uma apreensão única. E como fazer isto se não percebo que os fenômenos vividos pelo corpo sinalizam uma nova maneira de estar no mundo? Como vivenciar os processos existenciais colocando-me apto a incorporar o passado ao presente e olhar o futuro vislumbrando todas as suas possibilidades? Isto não será possível sem que me abra para a descoberta a partir da corporeidade.

Esta postura de abertura, segundo Merleau-Ponty (1999), significa estar no tempo, estar aberto para cada momento, contemplando a experiência de um modo consciente de maneira que cada instante se torne 
significativo. É usar a liberdade de ser para pôr-se em situação, afirmar o existir.

Penso que os temas apresentados serviram de suporte para que eu pudesse analisar e interpretar os depoimentos das mulheres que fizeram parte da presente pesquisa.

A seguir, passo a apresentar a trajetória que percorri para desvelar o fenômeno: "Mulher vivenciando o climatério". 


\section{A TRAJETÓRIA METODOLÓGICA}

Esse meu interesse no mundo vivido dessas mulheres concretiza-se com base em minhas vivências cotidianas como mulher, enfermeira e docente, voltando o meu olhar para o existir considerando uma reflexão subjetiva do vivido. Nesse sentido, expresso minha intenção em compreender o significado essencial dessa estrutura.

Assim sendo, orientada pelo referencial teórico-filosófico escolhido, busquei o sentido do vivido das mulheres climatéricas, destacando as experiências que abarcam a sua natureza como mulher. Para tanto, fiz uma reflexão sobre o meu passado, o presente e o futuro, mediante a minha própria percepção, almejando desvelar este fenômeno aos meus olhos, habitei-o, portanto, como uma das minhas moradas e com isso pude apreender o que ele tem de mais essencial.

Intencionei caminhar por este prisma, na história da vida de cada uma dessas mulheres, e apreciar o evento do climatério tendo como objetivo desvelar o significado de sua vivência da maneira como elas o percebem. Segundo Merleau-Ponty (1999), a cada momento o corpo exprime a existência, pois a fala exprime o pensamento e afetos. É dessa maneira que o corpo exprime a existência total, uma vez que a própria existência se realiza nele. 


\subsection{Os sujeitos da pesquisa, região de inquérito}

A região de inquérito ${ }^{*}$ deste estudo foi constituída por mulheres que estavam vivenciando o climatério, independente da profissão, do nível de escolaridade, da raça ou de qualquer outro atributo, por acreditar que os mesmos não interferirão na experiência do climatério.

Assim sendo, para a coleta de dados deste estudo não se fez necessário definir um local. A região de inquérito, portanto, foi a própria situação em que o fenômeno ocorre, o mundo vida, o período da vida da mulher compreendido entre os 48 e 55 anos de idade.

Lembrando que a menopausa caracteriza a ultimação da atividade folicular ovariana, culminando com a percepção, pela mulher, dos sintomas típicos do climatério, a escolha dos sujeitos da pesquisa foi definida a partir dos achados bibliográficos que afirmam que a fase do ciclo reprodutivo, na qual a mulher, usualmente, constata a ocorrência da menopausa, é aquela situada entre a faixa etária dos 48 aos 52 anos. Entretanto, durante a sondagem dos possíveis candidatos a sujeitos desta pesquisa, constatei alta incidência de mulheres histerectomizadas na faixa etária pré-estabelecida para participar da pesquisa. Por acreditar que esta característica poderia influenciar nos resultados ampliei a faixa etária para 55 anos de idade e procurei evitar sujeitos que tivessem sido submetidos a procedimentos que pudessem interferir na ocorrência espontânea da menopausa.

\footnotetext{
* Região de inquérito é a região de perplexidade, o local transparente das preocupações do pesquisador. Não é, portanto, um espaço e sim um contexto conceitual em que as pessoas agem (Merighi, 1993).
} 
Dessa forma, foram sujeitos da presente investigação mulheres que incluíam-se na faixa etária estabelecida e que se encontravam em amenorréia há 12 meses ou mais. Embora o climatério se estenda por um período maior do que 48 a 55 anos, optei por delimitar esta faixa etária por acreditar que outros fatores, relacionados à idade, poderiam influenciar o significado atribuído pelo indivíduo aos seus processos existenciais.

Faz-se necessário destacar que a abordagem destas mulheres dependeu do meu conhecimento e de informações de terceiros sobre a existência destes sujeitos. Evitei coletar os dados em Serviços de Atenção ao Climatério por entender que as mulheres já estivessem envolvidas com tratamentos médicos e, portanto, com possibilidade de terem sua atenção voltada, principalmente, aos aspectos fisiopatológicos relacionados a esta fase da vida.

O período de coleta de dados foi entre novembro de 2004 a janeiro de 2005. As entrevistas foram agendadas sendo que algumas foram realizadas nas residências das mulheres e outras nas dependências do seu local de trabalho.

Os discursos foram transcritos integralmente, por mim, imediatamente após sua coleta, preservando as idéias, a seqüência, a linguagem utilizada pelos sujeitos, bem como erros gramaticais, pausas e repetições. Não apenas as transcrições, mas a leitura dos depoimentos foi efetuada logo após a realização das entrevistas. Dei-me por satisfeita no momento em que as descrições das mulheres delinearam a sua vivência, mostrando sinais de 
desvelamento do fenômeno ser mulher vivenciando o climatério, ou seja, atenderam às minhas interrogações em função de seus conteúdos.

Obtive oito depoimentos das mulheres que vivenciavam esta fase da vida. No entanto, um foi excluído por não responder à questão norteadora.

Vale acrescentar que o número de mulheres participantes deste estudo foi definido pelas próprias descrições. Assim, o encerramento da inclusão de novos sujeitos foi decidido com base no conjunto dos dados coletados que evidenciou, tanto a riqueza como a abrangência dos significados contidos nos depoimentos. Neste sentido, sete discursos foram trabalhados e considerados suficientes para desocultar o fenômeno.

Para a identificação dos discursos das mulheres utilizei o nome de sete deusas da mitologia grega*: Ártemis, Hera, Tique, Afrodite, Deméter, Atena, Héstia; apropriando-me da idéia de Secco (2002) quando sugere que toda mulher representa um papel principal no desenrolar da sua história existencial e que há muitas deusas numa determinada mulher de forma que, na vivência do climatério, a mulher pode experimentar encontros com suas deusas interiores, não ficando dominada pelo arquétipo** de uma única deusa, nem sendo obrigada a vivenciar todas.

\footnotetext{
"Nominação extraída do livro: "Os Deuses do Olimpo" de Stephanides (2004).

** Arquétipo significa, etimologicamente, modelo primitivo ou imagem primordial que representa o inconsciente de uma experiência arcaica da espécie humana. No mito, os arquétipos remontam à tradição imemorial, pois pertencem a um mundo primitivo, porém ainda existente em algumas culturas (Secco, 2002).
} 


\subsection{A questão norteadora}

Situando o fenômeno em minha região de inquérito, ou seja, no mundo vida, no qual às experiências vividas combinam memórias e percepções de cada momento; no mundo experiencial das mulheres que estão vivenciando o climatério, direcionei minhas inquietações para as descrições obtidas nos discursos por meio da proposição da seguinte questão norteadora: Fale-me, como é para você estar vivenciando o climatério?

Por meio deste questionamento obtive os discursos e relatei, da forma mais fiel e precisa possível, a experiência e a percepção da vivência do climatério. Colocando o fenômeno investigado diante dos meus olhos descrevi a experiência de mundo dos sujeitos da pesquisa, reconhecendo que as experiências humanas são dadas como fatos da realidade, por isso não podemos apreendê-las em sua totalidade.

Optei por incluir os discursos das mulheres, como anexo a este texto, abordando algumas características presentes em seu mundo. Desse modo, a apresentação dos depoimentos na íntegra teve como objetivo possibilitar ao leitor maior compreensão sobre o fenômeno estudado (ANEXO A).

Faz-se necessário acrescentar que, por ocasião da apresentação do Projeto da presente pesquisa, no Exame de Qualificação, foi sugerido que a questão norteadora fosse reelaborada, de forma que não fossem salientadas questões específicas do climatério, mas sim a fase que estava sendo vivenciada pelas mulheres. Partiu-se do pressuposto que a expressão 
"climatério" traduz-se em termo medicalizado e, neste sentido, poderia ocorrer a possibilidade de indução de um discurso voltado para mudanças fisiológicas, em detrimento de aspectos relacionados a outros eventos típicos que envolvem este processo de transição para o envelhecimento. Assim sendo, com a finalidade de pré-testar a questão norteadora, obtive três discursos utilizando a seguinte questão: Fale-me, como está sendo pra você a vivência da meia-idade?

Os discursos, no entanto, obtidos por meio desta questão não responderam às minhas inquietações, já que as mulheres voltavam sua atenção para aspectos diversos da sua vivência e enfocavam o que estavam experienciando de mais conflituoso naquele momento de sua vida, sem ao menos tocar na experiência do climatério, objeto de estudo desta pesquisa.

\subsection{A obtenção dos discursos}

Os relatos da vivência do sujeito devem ser espontâneos e a sua descrição ingênua, ou seja, não interpretada. Nos discursos está contida a essência do que se busca conhecer e a intencionalidade do sujeito (Martins e Bicudo, 1989).

Vale ressaltar a interação que permeou a coleta dos dados. Durante o encontro foi criada uma relação empática entre a pesquisadora e a mulher que estava sendo entrevistada. 
Procurando estabelecer um clima favorável para que a mulher pudesse falar sobre o assunto, além de explicar os objetivos do estudo, solicitei sua autorização para a gravação do seu discurso. A gravação tem a vantagem de registrar todas as expressões orais, imediatamente, além de permitir ao pesquisador o acesso aos relatos e/ou descrições acerca do fenômeno que se está indagando, ao mesmo tempo em que deixa o pesquisador livre para prestar toda a sua atenção no sujeito, participante da pesquisa (Schraiber, 1995; Bruns, 2000).

No conjunto total da descrição, conforme nos ensina Martins; Bicudo (1989), evitei aspectos isolados do fenômeno e situei o objeto deste estudo dentro de um horizonte de familiaridade, buscando clarificar e interpretar o vivido por meio dos seus significados mais profundos.

A descrição constitui um passo importante no desenvolvimento da pesquisa fenomenológica, pois permite ao inquiridor o acesso à vivência original do fenômeno, bem como o acesso à intencionalidade do entrevistado. Ou seja, o sujeito que descreve sua experiência é situado e os significados das suas vivências emergem do seu real vivido. O discurso obtido é peça-chave para que se possa proceder a análise compreensiva (Bruns, 2000).

Para compreender a essência do fenômeno: mulher vivenciando o climatério, além de despir-me dos pré-conceitos, tentei aproximar-me do fenômeno com a firme intenção de captar seus significados, buscando tornálo transparente e passível de interpretação. 
Tratei ainda de descrever o real, que, segundo Merleau-Ponty (1999), é o que deve ser descrito, não construído ou constituído. Falei do "retorno às coisas mesmas", pois tudo o que sabemos do mundo, mesmo por ciência, o sabemos por meio de uma visão nossa ou de uma experiência do mundo sem a qual os símbolos da ciência nada poderiam dizer.

Conforme citado por Martins; Bicudo (1989), na pesquisa qualitativa, as descrições são tratadas interpretativamente e a preocupação incide sobre aquilo que os sujeitos da pesquisa vivenciam como um caso concreto do fenômeno estudado. O objetivo da investigação é coletar descrições e trabalhar a essência do fenômeno por meio dos discursos obtidos.

Durante as etapas que precedem a interpretação, de acordo com Merleau-Ponty (1999), todo o meu movimento enquanto pesquisadora foi em função de descrever a natureza da experiência tal como ela é vivida pela mulher climatérica, sem a pretensão de explicar ou de analisar o que via, mas almejando captar a essência do fenômeno.

Como mencionado anteriormente, procurei, conforme preconiza Martins; Bicudo (1989), relatar de forma precisa o que ocorre com a mulher ao viver suas experiências nesta fase da sua vida e, em termos fenomenológicos, almejei que as mulheres fizessem uma descrição noemática*, isto é, do seu modo de ser, dos dados da sua vivência que descrevessem de maneira, tão precisa quanto possível, o que ocorria com elas durante o período do climatério, de tal forma que as referências

\footnotetext{
* O Noema é o objeto constituído pela noésis, que é a descrição das diversas maneiras como o objeto se mostra quando é intencionado. É o aspecto objetivo da experiência vivida, isto é, o objeto considerado pela reflexão em seus diversos modos de ser dado; o percebido, o recordado, o imaginado (Ribeiro Junior, 1991).
} 
noéticas $^{*}$ pudessem ser apreciadas com o intuito de clarificar e auxiliar na interpretação da vivência.

\subsection{Considerações éticas}

Considerando o que preconiza a Resolução 196/96, sobre Diretrizes e Normas Regulamentadoras, que trata de pesquisa com seres humanos, as mulheres, como já salientado anteriormente, foram esclarecidas sobre 0 objetivo da pesquisa, bem como sobre a manutenção do sigilo, do anonimato da sua pessoa e do seu direito de participar ou não da mesma. Após estes procedimentos foi solicitado às participantes a assinatura do Termo de Consentimento Livre e Esclarecido para participar de pesquisa científica (ANEXO B).

Vale ressaltar que o projeto da presente pesquisa foi submetido à avaliação e aprovado pelo Comitê de Ética em Pesquisa da Escola de Enfermagem da Universidade de São Paulo (ANEXO C).

Em seguida apresento a construção dos resultados da pesquisa por meio da análise dos discursos dos sujeitos.

\footnotetext{
* Noesis é o "dar-se conta de", refere-se aos atos que o sujeito realiza que tendem a apreender o objeto: o pensamento, a percepção, a imaginação, à atividade da consciência (Ribeiro Junior, 1991).
} 


\section{CONSTRUINDO OS RESULTADOS}

\subsection{A análise dos discursos dos sujeitos}

A análise dos dados, à luz da fenomenologia, exige uma reflexão especial do pesquisador e esta reflexão revelará uma multiplicidade de vivências e o seu conteúdo correlato. Na análise fenomenológica dos discursos deve-se suspender todos os pressupostos sobre o objeto estudado (époché) e proceder à interpretação mais imediata de sua manifestação.

A pesquisa fenomenológica dirige-se para os significados como revelações sobre as percepções que os sujeitos têm acerca da vivência de um fenômeno, no caso a vivência do climatério. O que se constitui então são os aspectos estruturais, invariantes, os padrões que se repetem do fenômeno (Bruns, 2000).

A essência do fenômeno não será o fim da análise, mas o meio pelo qual se pode trazer à luz o que as experiências vividas apresentam de essencial. Para a análise dos discursos, objetivando o desvelamento do fenômeno da vivência do climatério, utilizei os procedimentos preconizados por Josgrilberg (2000) como pressupostos filosóficos de análise.

Segundo este fenomenólogo, o procedimento de análise visa aproximar a descrição/interpretação fenomenológica dos dados obtidos. Trata-se de detectar as Unidades de Sentido (US) resgatadas dos discursos, agrupálas, categorizá-las e proceder uma releitura a partir de categorias 
existenciais contidas no referencial filosófico adotado, enquanto fio condutor da análise dos dados.

Vale lembrar que na justificativa da escolha do referencial adotado para fundamentar a análise compreensiva e interpretativa dos achados deste estudo, mencionei e discorri sobre temas como corpo, mundo, espaço, tempo e liberdade, categorias existenciais citadas e trabalhadas por Merleau-Ponty.

Assim sendo, com este olhar, partindo das categorias existenciais acima citadas, iniciei a leitura e re-leitura dos discursos das mulheres procurando identificar unidades de sentido, isto é, aspectos dos depoimentos que tinham significado para mim, enquanto pesquisadora, e que respondiam à minha questão norteadora.

Após a seleção dos trechos de todos os discursos, os mesmos foram agrupados conforme as convergências (aspectos semelhantes). Posteriormente, cada agrupamento revelou um núcleo de pensamento, uma idéia central de todos os trechos ali contidos, que possibilitou a identificação de cinco diferentes categorias temáticas, aqui denominadas de Unificações Ontológicas*, que desvelaram que o ser mulher vivencia o climatério percebendo mudanças no seu corpo, vivenciando sentimentos de ambigüidade, conscientizando-se do mundo por meio do corpo no tempo e no espaço, refletindo sobre a sexualidade e reconhecendo novas maneiras de co-existir no mundo.

\footnotetext{
* Ontológica é o adjetivo usado para a ciência, no caso a filosofia, que trata do Ser enquanto Ser, isto é, do Ser concebido como tendo uma natureza comum que é inerente a todos e a cada um dos seres (Ferreira, 1999).
} 
Após a organização de todos os agrupamentos, procedeu-se a análise

de cada uma das unificações ontológicas, o que, basicamente, compõe a descrição dos resultados obtidos.

Antes de passar para a descrição de cada categoria/unificação ontológica apresento o esquema representativo da trajetória percorrida pelas mulheres na vivência do climatério: 
SEGUIRÁ PAGINA COM DESENHO E AS CATEGORIAS 


\section{UNIFICAÇÕES ONTOLÓGICAS REFERENTES À MULHER VIVENCIANDO O CLIMATÉRIO}

Para a análise e discussão dos resultados desta pesquisa, busquei compor as experiências vividas pelas mulheres durante o climatério em vários momentos de sua vida. Desse modo, foi possível aproximar-me das suas experiências perceptivas, lembrando que o corpo tem um movimento inacabado, ou seja, no movimento da existência está sempre refazendo-se, respeitando o seu processo natural. Para tanto, considerei minha própria cultura e identidade como mulher, bem como a minha história e o modo como as re-significo. Desvelar o fenômeno estudado foi também buscar a identidade dessas mulheres e o que mora dentro delas.

As categorias de análise revelaram a trajetória das mulheres durante a experiência vivida e, percorrendo o caminho ontológico no referencial filosófico de Maurice Merleau-Ponty, tive a oportunidade de compreender a vivência do climatério na perspectiva do ser-no-mundo, ou seja, desse Ser engajado num mundo objetivo e intersubjetivo.

A seguir, passo a apresentar a descrição de cada unificação ontológica. 


\subsection{Percebendo as mudanças no seu corpo}

O corpo se expressa em toda a sua existência. As mulheres, principalmente nas fases da puberdade e do climatério, percebem o seu corpo mudado. Toda essa expressão se dá mediante o vivido. O mundo que cada mulher vive é inerente ao que sente e também aquilo que não identifica, mas está lá, fazendo parte e interferindo de forma positiva ou não do movimento de sua vida. Ter consciência do que se passa é um processo de aprendizagem bem como um despertar para uma nova forma de existir.

Nesse particular, a mulher percorre caminhos imagináveis, mas ainda continua sendo si mesma. Pode ser tocada por novas sensações, olhares, sentimentos, por vezes familiar, ora estranho, mas sempre diante de possíveis descobertas e realidades.

A vida humana consiste em compreender que viver com todas as suas nuances é essencialmente con-viver, co-existir, o que nos conduz a aspectos ligados à comunidade, união, reciprocidade e liberdade (Capalbo, 1994b).

Conviver e coexistir consigo mesmo é o primeiro requisito para se viver com os outros. Ao voltar a atenção para o corpo, a mulher se dá conta de que mesmo que tenha passado anos sem notá-lo, seguiu o fluxo do tempo, moveu-se por entre fatos e atos, compilando dados, registrando vivências em sua memória e em seu corpo. 
A mulher vai aprendendo e compreendendo em cada uma das fases da sua vida qual é a função de seu corpo à medida que vivencia novas experiências em seu mundo. Começa a perceber como o seu corpo responde às situações, não somente no plano físico, mas também no afetivo-emocional e social. Quando o corpo muda, já vem identificado com as novas relações, mas também carrega as lembranças de sua vida, a sua história. O corpo da mulher ao mudar vai adquirindo novos hábitos e renovando o modo de ser e lidar consigo mesmo, como aquele que adere a uma nova coreografia, indo ao encontro de uma nova percepção, seja corporal, mental, afetiva ou social. Mesmo por que é o corpo da mulher que a ancora no mundo.

É por meio do corpo que a mulher se manifesta no mundo e é por intermédio do seu movimento que existe com o mundo, se vê no mundo, interage com as outras coisas e os outros seres.

Ao longo dos discursos das mulheres chamou a atenção o modo como elas percebem os sinais e sintomas e os situam em seus corpos numa condição que, para algumas, significava olhar para novos limites, imbuídas de novas sensações e desconforto:

\footnotetext{
"Tem dia que eu acordo e sinto frio, sinto calor [...] um suor que parece que eu entrei embaixo do chuveiro. É um calor muito cruel daqui pra cima (aponta o tronco) e no pé. Tudo isso na mesma noite. A gente fica vermelha que nem um camarão. O meu corpo mudou, eu pesava 48 quilos e tô agora com 75. A menopausa faz a gente engordar, começa a aparecer verruga, manchas, a vista fica fraca[...]." (Ártemis)
}

"Eu tive problemas no início da menopausa que era o fogacho, a irritação, o ressecamento vaginal, a insônia[...] eu tive muitos problemas [...] depressão." (Hera) 
"Começou a esquentar as mãos e depois começou a descer atrasado. Vários tempos na frente começou a parar de uma vez. Eu acho que não foi bom porque a mulher começa a sentir dores na perna, canseira. O normal seria é que não fosse embora (a menstruação). Eu me sentia bem quando tinha a menstruação regular. Às vezes a pessoa fica mais irritada, nervosa." (Héstia)

"Eu tava com 39 anos e a menstruação deixou de vir [...]. Eu engordei uns dez quilos nesses anos. Eu perco pouco (peso) só que ganho com facilidade." (Atena)

"Eu sinto alguns calorões. Eu ponho coberta, tiro coberta, ponho roupa, tiro roupa. Me sufoca. Não tem dia nem hora. Eu tive ressecamento na hora do relacionamento." (Deméter)

Essas verbalizações nos reportam à Sant'Anna (2001), quando afirma que o corpo é finito e sujeito a transformações nem sempre desejáveis ou previsíveis e, ao longo dos anos, muda sua forma, seu peso, seu funcionamento, seu ritmo. De forma que, o corpo de cada um pode parecer extremamente familiar e concreto em certos momentos, mas, em outros, bastante desconhecido e abstrato. Como pode ser observado nas falas que se seguem:

"Minha indisposição era total [...]. Eu tenho osteoporose comprovada nos exames. A pele ressecada, além das pintas horrorosas que aparecem [...] parece verruga. O que mais me chateia é ficar gorda, barriguda... eu não consigo emagrecer. Aquele calor insuportável, aquela suadeira. A menopausa dá ressecamento na boca. Até o cabelo fica ressecado." (Hera)

"No começo dava aquele calor e passava. Eu passei a ter mais problemas [...] eu me irrito fácil, tô mais estressada e com os nervos à flor da pele." (Tique)

"Eu viver do jeito que eu tô vivendo agora? Para quê? [...] olhar pro meu corpo e vê que tá caindo tudo? Não quero mais viver!" (Afrodite)

As mulheres buscam no corpo as marcas do processo de mudança e sofrem com a sua constatação. No entanto, é possível conhecer algo do corpo pela forma como trata-se dele. Às vezes, como uma "máquina", que 
tem que tomar um comprimido só por tomá-lo ou tratá-lo com consciência e perceber se, realmente, o que o corpo precisa é do comprimido ou se posso mudar parte da realidade para viver melhor.

"Procurei o G.O. (ginecologista) e ele falou que eu não tinha hormônio suficiente nem pra me manter como mulher. $O$ uso do hormônio eu rejeitava porque na minha família as mulheres nunca usaram nenhuma droga para suportar essa fase. Eu fumava muito [...] Começou as dores no peito, meu batimento cardíaco era forte e um certo aperto (no peito), minhas mamas ficaram túrgidas e doía demais, a barriga doendo bastante[...]. O G.O. falou: "pára de tomar o hormônio e toma isoflavona". Minhas manchas começaram a sumir, o buço diminuiu, o cabelo foi ficando fino, não tinha ondas de calor, mau humor, angústia, mas meu corpo não tava muito bom!!!" (Afrodite)

Nesse sentido, a percepção de que o corpo está mudando e perdendo suas funções fisiológicas, a estabilidade do humor, a beleza, enfim, pode colocar a mulher numa posição estática, como uma máquina que se deteriora dia após dia e para a qual não há conserto. É como se fosse um corpo sem vida, reduzido a uma massa obscura. Como se o que se está analisando se resumisse apenas as partes deste corpo sem considerar o todo indivisível que, em essência, melhor o descreveria:

\begin{abstract}
"Começou um calor da cintura pra cima, uma irritabilidade, uma agonia, uma angústia que foi me fazendo ficar meio doida. Eu arrancava a roupa e aquele mal estar não passava e eu sentia vergonha por que tava no meio de todo aquele pessoal. É um suor horroroso que escorria pelo pescoço, pelo cabelo [...] é horrível, pegajoso e tem cheiro forte, esquisito. Eu menstruava normalmente. Com 48 anos a menstruação começou a vir numa quantidade maior, era coagulosa e muito dolorosa. Eu tava sofrendo e ninguém entendia... as pessoas falavam: 'Nossa! Como você tá irritada! Nossa! Como sua pele tá escura!' Porque eu sou negra e não vou ficar vermelhão [...] ficam vermelhas a maçã do rosto e a ponta do nariz, o restante do rosto fica roxo. Eu tomei 'dilena' (hormônio) um ano. A menstruação parou. Fiquei maio, junho [...] setembro eu sangrei muito que eu não podia levantar. Fiz os exames de novo e tava com a dosagem (dos hormônios) boa." (Afrodite)
\end{abstract}

Referir-se ao corpo, ao universo, ao espaço, ao tempo como idéias, que se encerram em si mesmas, implica no risco de se perder o contato com 
a experiência sensorial e perceptiva da qual o corpo é o resultado e a conseqüência natural. É reduzir, simplificar o que é complexo e indivisível.

Merleau-Ponty (1999) afirma que por meio da fisiologia também é possível "encontrar" a existência, ou seja, por meio do entendimento dos processos vividos pelo corpo é possível encontrar o Ser. Apoiando-me nesta assertiva considero que é preciso entender que todo o conhecimento produzido na busca pelo reconhecimento desta organização maravilhosa que é o organismo humano, pela explicação dos processos de saúde e mesmo os de doença, não é, nunca foi e nem será em vão. O avanço da ciência deve auxiliar os homens a alcançar o controle dos males que os impedem de seguir o seu caminho rumo à felicidade, à plenitude de seres humanos.

É desejável que este movimento seja feito a fim de aprender a olhar a existência não somente com os olhos da carne e da mente, mas também com o coração, valendo-se da própria história, deixando-se ser tocada pela vida, independente dos limites e possibilidades. É necessário olhar para a experiência que se está vivenciando e colocá-la como horizonte, destacando as situações vividas enquanto motivadoras de crescimento, de aprendizado.

De qualquer forma, é por meio do corpo que se consegue resgatar a história. Para as mulheres deste estudo, as suas vivências foram acontecimentos passíveis de serem pontuadas quando ancoradas num determinado tempo e lugar.

Essas mulheres puderam refletir sobre a sua vivência como um momento em especial de sua vida. Pude constatar que muitas mulheres 
deixam, ao longo de sua vida, de entrar em contato diretamente com suas emoções, por não possuírem recursos para isso. Muitas vezes, ainda, esquecem de cuidar do corpo como algo inerente do existir. Com isso acabam não escutando o que o corpo lhes fala e, talvez por isso a impressão suscitada é a de não compreenderem o que sentem:

"Eu não tenho como explicar! Como eu vou explicar por que eu estou assim? A 'M' (filha) pergunta: 'mas, por que que a senhora está assim?' Eu digo: 'eu não sei!!' (Ártemis)

A fala de Ártemis aponta a necessidade de se considerar os acontecimentos da vida como fatos importantes e indispensáveis para a composição dessa complexa rede de vivências. Merleau-Ponty (1999) afirma que toda a recordação de uma vivência reabre o tempo perdido e nos convida a retomar a situação que ele evoca, levando-nos para o momento específico em que tal situação ocorreu. Dessa forma, o ser-no-mundo reencontra a origem da emoção. Isto se dá porque ele ainda está engajado naquela situação e não consegue enfrentar e/ou abandoná-la. É como se a vida tivesse mudado, mas algo o prendesse ao passado:

"Se você vê uma foto minha quando eu tinha 16 anos e vê agora?! Nossa Senhora! Como muda, muda muito! Eu sempre prestei atenção nisso." (Ártemis)

"Eu engordei (fez expressão de lamento). Eu tenho barriga, estômago[...] se eu engordo, aqueles quilinhos não querem ir embora. Eu não ponho mais vestido, ponho aquela roupa que segura mais. Quando eu era mocinha eu pesava 50 quilos e hoje eu tô com 76. Eu acho que meu corpo tá feio, o que tá ruim é minha barriga e os peitos que caíram." (Tique)

Ao pensar sobre algum assunto específico ou sobre a sua vida, a mulher resgata imagens internas capazes de desencadear lembranças, 
angústias, alegrias e podendo perceber que esta fase da vida, somada a outras experiências vividas, resulta em mudanças em seu comportamento, na sua postura e no autocuidado. Essas asserções podem ser compreendidas a seguir:

"Me tornei uma adolescente! Comecei a sair à noite e eu era a mais velha de todo o grupo. Eu adquiri um novo visual, modifiquei minhas roupas, meu cabelo [...] mas [...] meu corpo não tava muito bom!!!" (Afrodite)

Pode-se perceber, nesse relato, que o Ser vai interagindo com tudo o que o cerca, que tem em seu alcance e vai buscando entender o que se passa consigo. A mulher segue experimentando formas de lidar com as mudanças e desconfortos, ao mesmo tempo em que pondera entre o que acredita ser bom ou não para si. Este é o movimento do corpo em busca do equilíbrio como afirma Crema (1995, p. 55): Movimento e flexibilidade estão intrinsecamente relacionados; diante do vir-a-ser, a atitude maleável é a condizente com a sanidade e a evolução.

Assim, percebo que na vivência deste processo é importante que o corpo seja aceito na sua condição e imprevisibilidade estando sempre por ser re-apreendido. Essa atitude poderá amenizar a sensação de que o tempo se esgota no hoje e que nada mais poderá ser esperado do amanhã:

"Você valoriza muito o hoje [...] não sabe se vai ter amanhã. Ninguém tem certeza do amanhã!" (Hera)

Pela fala de Hera percebo que, apesar de estarmos num mundo concreto/palpável e sermos feitos de uma matéria que é perecível, somos 
ilimitados enquanto consciência. Compreendo então que o corpo é um objeto que age, move-se no mundo objetivo e é na sua atuação no mundo que o vejo revelando-se, a cada momento da existência, colocando em evidência o sujeito que percebe, assim como o mundo percebido. De forma que, a lente que eu utilizo para interpretá-lo é a que irá determinar a riqueza da sua descrição. O que devo ajustar, servindo-me dessa nova maneira de observar, é o meu olhar que pretende ver o objeto na sua inteireza.

Merleau-Ponty (1999) cita que o corpo observa, maneja, inspeciona os objetos exteriores, mas não é observado e tocado por si mesmo. Nesse sentido, necessita ser entendido pelas pessoas que o circunda, precisa ser apreendido a partir do outro. As limitações do corpo não podem impedir o Ser de continuar o seu processo de amadurecimento e crescimento, já que o que necessita ser considerado encontra-se além do corpo-objeto. Esta atitude de olhar além do corpo passa a ser motivada pelas suas próprias limitações. É a contradição, a ambigüidade determinando o equilíbrio e impulsionando o Ser a refletir sobre sua existência, que vai muito além desse corpo-objeto.

Se o corpo é a origem do nosso modo de ser e de reagir ao mundo, torna-se indubitável que ele seja a forma como relaciono-me com o mundo. Então, podemos aceitar que o mesmo mundo muda a cada fase vivida pelo corpo. O mundo intra-uterino, o mundo do bebê, da criança, do adolescente, do jovem, do adulto, do idoso. São vários mundos constituídos num único mundo, são vários corpos num único Ser vivendo em mundos diferentes e no encontro desses corpos o mundo se torna único (Josgrilberg, 2003). 
Entretanto, apesar das limitações do corpo físico chamarem a atenção para a idéia da perda de função, da inércia, o que, na verdade, necessita ser compreendido é que se trata da continuidade da vida em um corpo que é um eterno vir a ser. No entanto, a mulher que está experimentando as restrições impostas ao seu corpo encontra explicações para isto no processo de envelhecimento que vivencia e nos sentimentos ambíguos que despertam na fase pela qual está passando, próxima unificação ontológica que será apresentada a seguir:

\subsection{Vivenciando sentimentos de ambigüidade}

Dar-se conta de que algo nesse corpo está diferente implica num movimento de volta para si, de retomada. É como se, num determinado momento de suas vidas, as mulheres passassem a dirigir a atenção para dentro delas mesmas e percebessem que existiu o momento da busca pela liberdade, que acreditava estar fora delas e, agora, surge a oportunidade de exercitar a reciprocidade consigo mesma. É o movimento de voltar-se para si. É a tentativa de compreender o corpo como resultado de uma experiência vivida e inacabada que envolve sentimentos ambíguos, conforme manifestado nos depoimentos:

"Eu não sinto nada, minha vida não mudou em nada. Minha vida é normal... no íntimo nada mudou. A única coisa que eu sinto é o calor que vem de dentro pra fora que parece que vai até estufar o olho da gente[...]. É uma sensação estranha[...] e eu penso: eu nunca fui assim 
por que agora eu vou ficar, né? [...]. Daí eu ligo o rádio, eu canto [...] aí passa. Se a gente for por na cabeça isso aí [...] ai, meu Deus do céu [...] eu triste??!!" (Ártemis)

"A menopausa minha já passou [...] com esse frio que todo mundo tá sentindo eu sinto calor." (Hera)

Nas falas de Ártemis e Hera percebo que, quando refletem sobre a vivência do climatério, primeiramente, afirmam que nada mudou e que a vida segue seu rumo no mesmo ritmo de antes. No entanto, no momento seguinte dão a entender que algumas "coisas" modificaram-se. Talvez pela sensação de que a ausência da menstruação a coloca numa condição física de instabilidade, por causa dos sintomas e pelas preocupações com os possíveis riscos dos tratamentos. A incerteza aponta a necessidade de exploração da consciência em busca de respostas que não estão em outro lugar senão internamente nelas.

"Eu acho que eu sou normal e não precisa tá ocupando os médicos. Começa a doer do dedão do pé até a coroa da cabeça. O normal seria é que (a menstruação) não fosse embora." (Héstia)

Tudo isso torna-se exacerbado quando as mulheres aproximam-se de muitas informações que não se encontram em seu contexto de vida. Aparecem, por vezes, muitas alternativas de tratamentos em relação ao climatério, com o propósito de oferecer maior qualidade de vida. Diante de muitas dessas possibilidades, as mudanças corporais/físicas são olhadas como algo que se insere num processo de desidentificação do corpo feminino saudável, para uma nova construção e movimento que abrem espaços para sentimentos de inseguranças e incertezas: 
"Eu sinto dor na estrutura óssea toda. Quando eu comecei tomar hormônio eu comecei sentir super bem. Minha indisposição era total e comecei a sentir muito bem, mas com os debates que eu fui observando, que poderia causar o câncer, e na minha família tem a predisposição eu resolvi parar de tomar. Então eu acredito que para as próximas gerações as coisas vão ser melhor [...] porque vão trabalhando mais os hormônios [...] tirando um pouco da química porque pode fazer esse câncer [...] Eu não quero pagar pra ver [...]." (Hera)

"Eu rejeitava o uso do hormônio [...] minha família é uma família de cancerígenos [...] eu tabagista [...] tomando hormônio?!! Eu negava! [...] Eu sangrei muito [...] eu não podia levantar [...] pensei: ' [...] daqui a pouco vou ter que fazer uma histeré (histerectomia)'. Aí eu fico louca de vez! [...] tirar o útero [...] sem ter câncer?!" (Afrodite)

De uma forma ou de outra é pelo corpo que a mulher se dá conta da sua nova condição. É o corpo chamando a atenção para si, almejando ser percebido. Nesse sentido, destaco alguns trechos extraídos dos depoimentos das mulheres:

"Hoje eu vivo bem, eu trabalho bem o problema da menopausa porque já acostumei a levar a vida como uma pessoa menopausada tem que ser [...] um dia bem-humorada, outro malhumorada. É uma coisa que eu vou ter que conviver pro resto dos meus dias. Minha vida eu levo o melhor possível dentro do meu limite. Eu me sinto bem sem ela (a menstruação) [...] se não fosse as conseqüências [...]. Se (o hormônio) faz mal é preferível a gente ter uma velhice não tão confortável, mas sem esse risco (do câncer). [...] a médica falou que o hormônio não engorda [...] que é os maus hábitos que a gente adquire [...] minha dieta foi feita por nutricionista e eu não consigo emagrecer porque eu não como tanto assim pra dizer que eu tô gorda por isso [...] às vezes faço exercício e não vejo um resultado [...]." (Hera)

As mulheres parecem apresentar dificuldades em assumir que tais alterações físicas relacionam-se com o climatério. Talvez por desconhecerem a evolução do processo e sua repercussão sobre seu corpo e sua vida. Referem sintomas que antes não sentiam e que causam desconforto, mas os mantêm no âmbito da normalidade. É como se estivessem olhando para sua condição física, percebendo as alterações a distância, como espectadoras, porém sem, inicialmente, estabelecer relações de causa e efeito, como se observa na fala de Atena. 
"Eu nunca tive nada disso (sintomas). Tenho uma vida normal [...]. Eu engordei uns dez quilos nesses anos. Eu perco pouco (peso) só que ganho com facilidade." (Atena)

Esse fato remete-nos a idéia de Merleau-Ponty (1999), quando afirma que o sujeito deve ter consciência de que o seu mundo é a soma de todos os meios circundantes, ou seja, que o climatério faz parte de um universo maior, mas para isso é preciso que a mulher, num primeiro momento, estabeleça um modo de sentir o seu próprio corpo mediante a observação e o entendimento daquilo que percebe.

É necessário que cada situação momentânea, vivida pela mulher, chame a atenção sobre si. Seja uma doença, uma dor, ou algo bom acontecendo que represente para ela apenas partes de um processo, ou seja, momentos de seu cotidiano que integram a totalidade de seu Ser. Que a experiência isolada de um fato não exija, cada vez mais, uma atitude singular e a desvie do seu potencial enquanto Ser integrado à existência. Que a dor, o fogacho, as mudanças corporais, que são condições pontuais e que, certamente, fazem parte de um todo significativo, deixem de ocupar o centro de sua existência.

Tal atitude poderá libertá-la do seu meio circundante, daquela experiência específica, e permitir que a mulher se veja enquanto um Ser vivendo num mundo, sendo no mundo. Para tanto, a distância que ela estabelece entre si e seu corpo e, até mesmo, tudo que está entorno dele, simboliza seu processo de apropriar-se do próprio corpo e daí compreendêlo. Nessa situação, pode ser ainda que, inconscientemente, as mulheres 
adotem esta postura diante das alterações corporais e, posteriormente, se coloquem no papel de auto-observadoras a fim de interpretarem o que sentem. Conforme se verifica na fala de Hera:

"Hoje eu tô bem[...] talvez amanhã você não me encontre nesse bem. Talvez amanhã eu tô caída [...]. Não é porque a gente quer não [...]. Eu acho que não tem falta de nada [...] eu acho que a felicidade é uma coisa que a pessoa cria. Acho que isso não existe mesmo assim não! Acho que felicidade é assim: hoje você tá [...] você agora tá e daqui dez minutos eu não tô [...] oscila muito [...] e isso principalmente na menopausa não precisa motivos pra pessoa ficar infeliz [...]. Eu tenho tudo pra ser feliz e não tô [...]. o nosso humor depende dos hormônios." (Hera)

Vale lembrar que a questão colocada como norteadora da entrevista: "Fale-me, como é para você estar vivenciando o climatério?", não necessariamente referia-se a mudanças físicas, porém suas falas verbalizavam a mudança de humor, as ondas de calor, o ganho de peso, ou seja, mudanças que manifestavam em seu próprio corpo. No entanto, refletir sobre a vivência do climatério implica em algo mais que isto. No início dos discursos, as mulheres não expressavam mudanças em seu corpo físico. No decorrer dos mesmos, apareceram sinais de prováveis mudanças, identificando que realmente algo havia mudado, este foi o início de um processo reflexivo.

"Eu nunca tive grandes experiências, não tive muitas diferenças. Eu passei a ter mais problemas [...]. Eu já fui na psicóloga [...] mas [...] eu não dou tempo pra mim [...] não faço aquilo que pode ser bom pra mim [...]." (Tique)

"Eu fiquei mais livre porque todo mês é aquele compromisso. Eu tô mais tranqüila. Eu não tomo nada e não fui ao médico. Veio normal, vai ter que ir normal. Tem um tempo que passa (os calorões) [...] ou acaba, ou a gente se acostuma. Eu não tenho nada!" (Deméter) 
Pude perceber que, na medida em que falavam, seus olhares voltavamse para algum lugar longe dali; as suas expressões faciais/corporais indicavam que estavam diante de um processo indescritível no qual o próprio Ser se fazia escutar/ouvir a partir da fala.

Esta atitude, esta maneira de expressar, confirmou para mim e mostrou para as mulheres, sujeitos do estudo, que o climatério é um processo e não um momento solto na vida da mulher e a menopausa é apenas mais um dentre uma série de sinais e sintomas. Apesar disso, a mulher tem a possibilidade de melhor compreender o seu corpo, por meio de sua própria vivência corpórea.

Foi preciso que as mulheres começassem a pensar sobre a sua vivência para que, então, outros sentidos se manifestassem, conforme podese perceber nas falas:

"Eu não sinto nada, minha vida não mudou em nada [...]. Eu sinto uma tristeza tão grande e aquela vontade de chorar." (Ártemis)

"Eu tô buscando e não cheguei à conclusão nenhuma do porque que essa tristeza me bate [...]. Tenho tudo pra tá feliz e não tô. Tem vez que eu não arrumo o cabelo, eu ponho ele pra trás; a roupa é a pior que eu tenho, porque eu acho que do jeito que tá minha alma eu tenho que vestir." (Hera)

Oscilar entre uma sensação de estabilidade e segurança e a impressão de que algo não está como era antes, que não se está bem, ajuda a mulher a encontrar o seu equilíbrio.

Esta constatação é apontada por Merleau-Ponty (1999) quando comenta que o que nos permite centrar nossa existência é também o que nos impede de centrá-la absolutamente, e o anonimato de nosso corpo é 


\section{Unificações ontológicas}

inseparavelmente liberdade e servidão. A ambigüidade do Ser no mundo se traduz pela ambigüidade do corpo e a ambigüidade do corpo se compreende pela ambigüidade do tempo.

Reconhecendo esta ambigüidade, a mulher consegue amenizar os conflitos internos e alcançar a sensação de que no fundo, realmente, nada mudou. Esta condição reforça a idéia de que só nos conhecemos porque reconhecemos a presença da ambigüidade e o homem é um ser ambíguo, sendo ele o próprio ir e vir da existência, vivenciando períodos de liberdade e servidão.

Neste ir e vir, no dia-a-dia do seu viver, o Ser percorre o seu espaço. Envolto num emaranhado de sensações movimenta-se no mundo. Este mundo, que não está territorialmente demarcado, que lhe foi dado já aberto por um acontecer, por um sentir, por um mover-se corporal. É o que se chama de invisível no visível. Nele o Ser vive suas experiências com autonomia e dependência entrecruzadas. É a contingência e a liberdade no existir humano (Capalbo, 2003).

Assim sendo, o homem mostra-se como esse vaivém da existência que, ora se deixa ser corporal, ora se dirige aos atos pessoais. Contudo, o homem não é um psiquismo unido a um organismo. Trata-se de um todo significativo, já que é possível reconhecer que um processo orgânico ou existencial desencadeia um comportamento humano, ou seja, entre o psíquico e o fisiológico podem haver relações de troca capazes de motivar a transformação do Ser. Para alcançar isto o Ser precisa acreditar que seu 
corpo e sua alma unem-se a cada instante no movimento da existência (Merleau-Ponty, 1999).

Dessa maneira, as experiências vividas pelo corpo, devido as alterações fisiológicas e psíquicas, devem ser percebidas e elaboradas, mesmo que num primeiro momento isso represente a perda da mobilidade $\mathrm{e}$ da possibilidade deste ir e vir do corpo, ou seja, um movimento também natural que faz parte do seu processo existencial e que, por estar ancorado no corpo, põe em evidência a natureza humana que é finita, mas, nem por isso, se esgota no fazer do dia-a-dia.

Esta forma de reagir aos processos de vida se confirma na idéia de que toda a reflexão humana deve ser uma motivação para a transformação da experiência em direção a horizontes mais desejáveis e que tudo que mobiliza o sujeito, que é capaz de causar impactos em si, tem o poder de suscitar um esforço que atua na transformação do modo de ser e estar no mundo (Kublikowski, 2001).

Viver as experiências por meio do corpo e buscar compor um "corpo novo", essa é a grande questão da existência. O corpo do qual falamos não é o corpo-carne que fenece, mas um compilado de vivências. Um corpo vivo que leva consigo todas as marcas, incluindo o sofrimento, sinalizando o caminho para a realização do Ser.

Ir ao encontro de si mesma significa ter que entrar em contato com o próprio corpo, com suas histórias, limitações e possibilidades, a fim de preservar e transformar a própria morada. Significa conscientizar-se do 
mundo por meio do corpo, possibilidade vislumbrada na próxima unificação ontológica extraída dos depoimentos das mulheres.

\subsection{Conscientizando-se do mundo por meio do corpo no tempo e no espaço}

A consciência da corporeidade pode se dar no âmbito físico, moral e científico. A corporeidade mostra a maneira que a mulher se desvela em seu existir, no seu mundo, sendo autora de sua própria história. É presença, é a identificação do Eu no sentido da presença do outro, de como vivencia a sua corporeidade tanto em seu modo mais mecânico, até o inelegível ou sensível.

Merleau-Ponty (1999) afirma que o corpo é o veículo do Ser no mundo. Para este autor, ter um corpo é juntar-se a um meio definido, confundir-se com certos objetos e empenhar-se continuamente neles. Por encontrar possibilidades de manejar objetos, por estar nesse movimento que o leva em direção ao mundo, o sujeito/corpo encontra a certeza da sua integridade e a certeza de que seu corpo é o pivô do mundo. Assim, torna-se possível conhecer as várias faces deste objeto de carne, pois pode-se dar a volta em torno dele e tomar consciência do mundo por meio deste mesmo corpo. Só assim é possível ver-se a si mesmo!

Na fala abaixo apresentada Ártemis comenta: 
"Você se olha no espelho e pensa que a gente muda tanto! A idade vai chegando e as coisas não são mais como antes! Antes a gente era jovem [...] podia rir mais [...]." (Ártemis)

E continua:

"A 'Ártemis' (disse referindo-se a si mesma) é a mesma só muda as rugas. O corpo a gente vê toda a hora [...] as gordurinhas, a barriga [...]. Eu sou um pouquinho vaidosa!" (Ártemis)

Ártemis parte da imagem do corpo atual e compara a imagem real com aquela que possuía, argumentando que o corpo que gostaria de ver refletido no espelho era aquele de anos atrás. Relaciona o que vê com a intenção de manter-se bela e encontra na sua própria história as motivações:

"Eu tenho um casal de filhos moços, três netos e eu adoro meus netos, graças a Deus!" (Ártemis)

Assim como Ártemis, Tique e Afrodite dizem:

"No começo, que eu perdi a menstruação, eu senti falta porque eu achei que tava muito nova e via pessoas com 50 anos ainda menstruando [...]. Hoje eu tô mais liberal [...] posso conviver [...] eu viajo, passeio, jogo baralho, jogo vôlei [...] embora com os mesmos problemas do lado mas eu tô conseguindo dar um pouco de espaço para mim também." (Tique)

"Eu já criei meus filhos, criei uma mulher que tem uma filha mulher, que viveu comigo tudo o que eu vivi." (Afrodite)

Noto, por meio dos depoimentos dessas mulheres, que é preciso que o sujeito se esforce para alcançar esse Ser que está ali presente e vivo neste corpo que se vê projetado no espelho percebendo que, além daquela superfície corpórea, existe uma aglutinação de vivências que dão forma 
àquilo que os olhos nus não conseguem perceber sem a lente da inteireza, da complexidade.

Quando percorro com o olhar, primeiramente, o mundo ao meu redor e, em seguida, percebo meu corpo atuando neste grande cenário humano, inicio um processo de autodescoberta durante o qual o meu corpo assume, a cada momento, posturas e ritmos diversos. Como nos discursos de Afrodite:

\begin{abstract}
"Eu acho que eu cresci muito nessa fase do climatério. Eu comecei a mudar. Não foi a mudança no corpo que detonou o processo [...]. Eu não tive uma puberdade normal, eu não assumi minha menstruação e só fui querer ficar com ela quando eu descobri que sem ela eu ia murchar, quando já tinha 40 anos. Sem ela eu ia ter que reaprender a viver. Não é fácil! Pra ter um climatério confuso como o meu é porque havia outras coisas envolvidas. Minha vida pregressa contou muito. Até eu entender o que era, que horror! Eu vim me conhecer quando eu entrei nessa fase do climatério. Eu acredito até que eu tenha entrado no climatério com uns 44 anos, mas eu não me observava, eu não prestava atenção. Eu só vivia pros outros." (Afrodite)
\end{abstract}

Quando as mulheres iniciam o movimento de olhar-se e buscar decifrar-se, por meio das suas vivências, passam a perceber que há ali algo mais profundo e intenso, que precisam trazem à luz.

Considerando-se que, nas diversas fases da nossa vida, não somos puramente carne, mas que nosso corpo possui dimensões palpáveis, características passíveis de descrição na sua superficialidade, alcançaremos também perceber que existe uma espessura neste corpo e que por meio dela pode-se chegar ao âmago das coisas, fazendo-nos mundo e fazendoas carne. Conforme cita Merleau-Ponty (2003, p. 132): É unicamente ele (o corpo) [...], que nos pode levar às próprias coisas [...], que não somos [...] seres planos mas seres em profundidade, inacessíveis a um sujeito que [...] nos sobrevoe, só abertas, se possível, para aqueles que [...] conosco [...] coexista no mesmo mundo". Esta é a noção de vida em reciprocidade. 
Pensando dessa forma retomo à questão das limitações físicas, dos sinais e sintomas do climatério e aproprio-me deste corpo atual como sendo um retrato de uma experiência biológica, mas sempre reafirmando o fato de que existe um corpo habitual, original. Este corpo habitual pode ser assimilado como o fiador deste corpo atual, desgastado. Para tanto, é preciso que se reencontre a origem do objeto (do corpo) na própria experiência, pois só assim a consciência conseguirá "saber de si”. Será preciso entender o corpo como Ser impessoal que independe do movimento de suas partes isoladamente e que é origem de todo o movimento (MerleauPonty, 1999).

Cada organismo tem o seu próprio modo de comunicar-se com o mundo. Toda a percepção consciente que a mulher tem de si significa que ela experiencia o que está ocorrendo. Muitas mulheres perderam essa habilidade de estar presentes e sintonizadas com seu próprio corpo e o vêem como o corpo inespecífico de uma mulher. Entretanto, é de seu corpo que ela deve aproximar-se cada vez mais e sentir o que realmente ocorre internamente, como evidencia a fala de Afrodite:

"[...] passei três anos saindo à noite [...] que coisa boa! Ai que maravilha! [...] dancei bastante. Danço muito ainda [...] só que hoje eu já começo a sentir que um esforço maior já me cansa. A noitada já não dá mais [...]." (Afrodite)

Agindo desta maneira, é possível que, no cume da experiência, no desenrolar dos acontecimentos, o Ser perceba que não pode mais ser sustentado por este invólucro frágil, que o limita, circunscreve, que ele pode 
ir além dessa circunscrição, mesmo que, num primeiro momento, este reconhecimento se dê à custa de sofrimento.

As mulheres expressam ainda em seus discursos:

"Às vezes dá vontade de ir embora, largar tudo! Eu sinto uma tristeza tão grande e aquela vontade de chorar. Eu associo essa tristeza a esta fase [...] porque antes eu não tinha nada disso [...]. Quando vem essa vontade eu resolvo sozinha. Bate cansaço... aquelas ruguinhas que vão aparecendo [...] eu olho no espelho e penso que quando eu tinha uns 30 anos eu era bonita! Tenho medo de ficar doente e dependente dos outros." (Afrodite)

“Tenho, às vezes aquela desesperança total da vida. Aí eu penso: 'eu tô acabada!'. Essa tristeza a gente não sabe de onde vem. Ela vem é da alma mesmo. Tem hora que eu fico pensando assim: 'Ah! Eu vou pegar uma estrada e vou andando sem destino!' Quanto mais a pessoa quer arrancar de você o que é que você tem, pior vai ficando [...] aí você começa a chorar e vem aquela coisa que eu não sei de onde vem [...] aquela agonia. Deve ser realmente da menopausa [...]. Não é estar acompanhada que me tira dessa sensação ruim." (Hera)

O desejo de ir embora, a angústia, a tristeza podem representar o impulso para a retomada do caminho, a manifestação da consciência que reconhece seu poder de extrapolar os limites do corpo-carne/invólucro. Porém, este processo/atitude também desencadeia sensações desgastantes e isto suscita angústia, conforme se verifica na fala de Tique e Afrodite:

"Estou mais sensível, mais mole com as coisas. Se eu vou num lugar que tá tocando uma banda (por exemplo) é uma emoção! Não tem porque tanta emoção, mas alguma coisa mexe comigo. Não sei se é porque me lembra o tempo de criança. Eu pouco paro pra ficar analisando as coisas, olhar no espelho. Quando vou me olhar já me acho gorda! Eu não costumo ficar sozinha comigo mesma, não dou tempo pra mim, pra fazer alguma coisa pra mim. Eu não tenho parado pra pensar, eu sou mais agitada. Acho que se eu ficar sentada (pensando) pode vir meus problemas na cabeça, as outras coisas que eu não consegui resolver [...]. Vai ficar sem resolver [...] ou sei lá! Mentalmente eu tô sempre cansada." (Tique)

"Eu vivia embaixo de uma angústia, uma amargura que eu não sabia de onde vinha. Nesse período aumentou! Eu chorava, vivia com vontade de sumir. Eu tava horrível. Tinha dentro de mim um mal, estava sofrendo [...]. Não era uma tristeza. Quando eu olhava no espelho eu sentia que não era a mesma pessoa e que eu estava sofrendo. Nem era angústia nem 
era tristeza. Fiquei três dias sem sair de dentro de casa, não falava com ninguém. Eu não queria enxergar o que tava acontecendo comigo. Eu tomei ansiolítico pra poder me suportar. Você não suporta as outras pessoas. Eu comecei a me sentir como se estivesse inválida. Minha parte emocional tava no chão, nada tava bom! Não era falta de afetividade, era alguma coisa em mim mesmo. Não tava preocupada se o mundo ia rolar pra cima ou pra baixo." (Afrodite)

O estado de medo, tristeza, agitação, torna-se barreira para que a mulher sustente seu "novo invólucro", para organizar sua vida de um outro modo, aprendendo a buscar nela a simplicidade, agindo com leveza e vindo a compreender que a sua liberdade está na possibilidade de ir além.

Enfim, encontrar-se no corpo, sentir-se habitando um corpo e por meio dele existindo num mundo de fato, pode impactar o sujeito. Mas, como já dissemos, é no movimento que se descobre a direção. É a corporeidade como berço das experiências do vivido. O corpo é o unificador e o unificado, ele mostra a roupa dos dois lados, o direito e o avesso ao mesmo tempo (Pokladek, 2002).

Crema (1995) afirma que ao dar-se conta de si, uma alquimia transformacional é dinamizada no indivíduo. Quando o sujeito torna-se cônscio e atento, testemunhando este turbilhão de sentimentos que a reflexão sobre sua vida suscita, uma mudança transcorre, pois, para testemunhar esta sua condição o Ser faz um movimento de desidentificação, abrindo um espaço criativo, propício à transformação.

Nesta busca por ser o que se é, pela felicidade, o sujeito agita-se interiormente. É como se estivesse em pleno turbilhão existencial. E, por necessitar de uma explicação para o seu desassossego, ele retoma a busca pelas justificativas e é no corpo que pretende encontrá-las. Isto porque as respostas aparecem mais rapidamente quando enfoca-se as deficiências 
desse corpo, as falhas na sua constituição, afinal, de alguma forma é preciso dar conta de responder às suas inquietações:

"Eu não tenho problemas mais por causa de eu não produzir (não ter tido filhos). Eu acho que a menstruação da mulher é a saúde da mulher [...] desde o momento que vai embora (a menstruação) não fica mais aquela saúde que ela tinha. Ela começa a mudar. É uma coisa muito estranha. Eu me sinto só!" (Héstia)

Convém ressaltar que a meia-idade feminina pode ser um período de satisfação e fruição, ao serem aceitas as próprias realizações sem amarguras. A "menopausa", no entanto, pode representar um golpe na autoestima feminina pela perda da função procriativa, e por isso um marco de passagem para o vazio, com desconfortos físicos, que variam em grau e duração de uma mulher para outra. Como se observa na fala de Tique:

"No começo que eu perdi a menstruação eu senti falta porque eu achei que tava muito nova e via pessoas com 50 anos ainda menstruando. Enquanto eu tava menstruando eu podia engravidar e queria muito engravidar. Há uns anos atrás meus exames "falou" que eu ainda tava fértil, embora sem menstruação. Eu guardei modess (absorvente) por muito tempo. Tinha cólica e ia olhar na folhinha (calendário) e era a época (de menstruar)." (Tique)

Ao mesmo tempo, a menopausa também anuncia novas liberdades que, se não puderem ser reconhecidas, acabam por serem desperdiçadas e esta fase do ciclo reprodutivo termina por significar somente a perda da capacidade de reencontrar o prazer, de procriar (Kublikowski, 2001).

Neste contexto, não se pode negar que uma outra forma de expressão da sexualidade é a reprodução. Percebe-se que a sexualidade permeia as relações e tem como uma de suas manifestações a idéia da procriação, da perpetuação da espécie e, do ponto de vista existencial, da eternização do 
Ser. Esta afirmação reporta-me a um outro aspecto da vida da mulher climatérica:

"Eu queria ser mãe e quando as regras deixaram de vir eu pensei: "agora é que não vai mais ter filhos mesmo, né"?!" Daí a idade vai passando [...] são 40, 45 (anos) e a mulher vai ficando velha. Passava tudo isso na minha mente [...]. Apesar de que minha mãe teve um filho com 51 anos. Mas ela deve ter menstruado mais tarde e ter ficado mais tempo menstruada, por que a menstruação é que indica se a mulher pode ter filhos ou não, né? Eu me sinto só. Se eu tivesse tido filho talvez eu tivesse uma companhiazinha pra mim." (Héstia)

Encontrei em algumas falas que a vivência desta fase da vida traz para a mulher a constatação da incapacidade reprodutiva, ou seja, com a menopausa dá-se por, se não encerrada, dificultada a possibilidade da procriação, do Ser perpetuar-se pela geração. Afinal, procriar é uma das formas mais naturais de enraizar-se no mundo, é manter-se "sendo no mundo", mediante a sua história de vida:

"Eu gostaria muito de ser mãe mais uma vez. Depois da menopausa eu tenho medo de engravidar. Eu me previno, ele (o marido) usa preservativo porque eu tenho facilidade pra ter filhos. Eu tenho vontade de pegar uma criança porque a gente sente falta." (Deméter)

Nas falas de Héstia e Deméter desvela-se a idéia de que a menopausa se apresenta como a marca fatal do "início do fim". Se assim o é, não se estranhará quando a mulher manifestar a intenção de manter-se sempre presente por meio da reprodução. Os filhos representam a possibilidade da continuidade da sua geração, a "fincada" da bandeira no território, o domínio do espaço.

Neste momento da vida é importante que o Ser compreenda que o fato de termos passado pelo mundo e nele vivido como seres engajados uns aos 
outros, de forma a compor um Todo Maior que é o próprio Universo, pode ser o que venha a nos confortar. Se estamos no mundo aí permanecemos enquanto essência. De tal forma que, saber-se experimentando o corpo no mundo, o peso do espaço, do tempo, do próprio Ser é ter em torno de si mesmo um tempo e um espaço de perpétua pregnância, parto perpétuo, geratividade e generalidade, essência e existência brutas que são o ventre e o nó da mesma vibração ontológica. É a forma autêntica de estar no mundo, ser no mundo, manter-se no mundo (Merleau-Ponty, 2003).

Diante de seus conflitos, todavia, o Ser vai percebendo que o problema não está nas suas deficiências e que todo o movimento do seu corpo serve para indicar-Ihe o caminho da autodescoberta e do encontro consigo mesmo. Isto é possível porque o corpo é o sujeito de um comportamento e, enquanto edifício químico ou reunião de tecidos, é formado a partir de um fenômeno primordial do corpo-para-nós (aquele que é igual a todos os corpos dos outros homens) e do corpo percebido (aquele que vive a experiência humana). E, ainda, a consciência não é mais uma consciência constituinte, como um puro ser-para-si, mas como uma consciência perceptiva, como sujeito de um comportamento, como ser-no-mundo ou existência. A existência é o ser-no-mundo (Merleau-Ponty, 1999).

Assim sendo, entendo que pelo seu corpo a mulher se dá a conhecer e pode ainda conhecer o outro. Percebo que sua consciência é inerente a um mundo que lhe pertence e é preciso agora distingui-la do corpo objetivo, tal como descrito pela fisiologia. 
Para Merleau-Ponty (1999), o sujeito não torna-se completamente uma coisa no mundo. A existência corporal, enquanto possui órgãos dos sentidos, nunca repousa em si mesma e sempre põe a pessoa diante do propósito do viver em seu tempo natural, ou seja, o tempo presente está sempre para recomeçar.

Faz-se necessário conceber a percepção, não mais como uma constituição do objeto verdadeiro, mas como minha inerência às coisas. É justamente por meio do meu corpo que percebo o corpo de outrem como um prolongamento miraculoso de minhas próprias intenções, uma maneira familiar de tratar o mundo. Doravante, como as partes de nosso corpo em conjunto formam um sistema, o corpo de outrem e o nosso são um único todo, o verso e o reverso de um único fenômeno (Merleau-Ponty, 1999).

Sendo este ir e vir, o verso e o reverso, o eu-individual e o eu-coletivo é que se pode constatar que a corporeidade engloba corpo e espírito. É uma totalidade de carne e espírito que se entrelaça para a evolução do Ser do homem na existência. Um corpo substância e um corpo vida simultaneamente. O homem em seu corpo está em relação consigo e com o outro enquanto corporeidade e o corpo humano é humano porquanto é meu, teu, dele, dela, é corpo de um sujeito e é nessa relação do corpo no mundo, enquanto uma totalidade significativa, que o homem se constrói como sujeito na existência. O corpo existe para revelar as "minhas" possibilidades neste existir, o corpo existe como ser-no-mundo (Freitas, 1999).

Como ser-sendo-no-mundo, Afrodite diz: 
"Eu tenho que começar a ter uma vida mais tranqüila para que aos 60 anos eu esteja bem [...]. Eu não levo a vida e não tenho a fisionomia de uma mulher de 51 anos. O meu corpo não mostra, mas eu tenho 51 anos. A gente nunca tá pronto pra morrer, mas se por acaso tivesse que falar: 'Pronto! Tô pronta!' eu falaria hoje: 'Estou!'. Tenho medo? Tenho! Tenho medo de ficar sozinha e não ter com quem conversar. Tenho medo de sentir uma dor e não ter pra quem ligar [...] mas isso já sou eu a ' $A$ ' que tem um monte de medo, um monte de neura [...] mas meu lado hormonal tá controladinho. É a segunda adolescência! Pode ter certeza que é!" (Afrodite)

As palavras de Afrodite levam-me a confirmar que, conforme já citado por Freitas (1999), o corpo é o solo firme para a construção do sujeito e a compreensão do corpo revela a necessidade de uma abertura para o compartilhar do existir, evitando o esmagamento da corporeidade que transcende à concepção apenas do corpo biofisiológico.

Compartilhar o existir torna-se possível quando percebemos a nossa inerência ao mundo e a outrem; quando compreendemos que só podemos existir porque estamos no mundo com outrem.

Consoante a esta idéia, entendo que apreciar a vivência da mulher no climatério é ver-me ali e, ainda mais, é entender que o que vejo ali só é visto por mim e por mais ninguém. Isto se dá, pois o que procuro no outro é o que me une a ele e ao mundo. O que propicia este acontecimento é a constatação de que o mundo é um prolongamento do nosso corpo e cada um se sabe e sabe os outros inscritos no mundo. O que sente, o que vive, o que os outros sentem e vivem não são ilhotas, fragmentos isolados do Ser, mas tudo isso é SER, tem consistência, ordem, sentido e há meio de compreendê-lo (Merleau-Ponty, 2003).

A mulher tem condições de vivenciar seu corpo, não apenas como um corpo, mas como uma "mulher que habita o corpo", como um universo único. Como aquela que percebe o próprio som, e que sabe que o sentido do 
próprio corpo é único. Nesse sentido, é possível cada mulher experienciar o climatério de modo semelhante a outras mulheres, mas também diferente, pois, mesmo no oculto consegue despertar o seu senso de percepção aprendendo a ouvir seu próprio corpo. Ao entrar em contato consigo mesma propicia abertura para transformar-se e agir de modo diferente, sendo capaz de fazer uma reflexão valendo-se daquilo que antes era irrefletido. Reconhecendo como o mundo lhe é dado enquanto participa dele.

Então, pode-se sugerir que a mulher no climatério, ao perceber-se exteriormente, percebe seu corpo no mundo, está no mundo e nele permanece sendo-com-o-outro. A mulher é um Ser de relações e por meio delas dá-se conta de seu corpo co-existindo com outros no convívio social, na intercorporeidade, no movimento que aproxima e distancia o corpo de si mesmo, de nós mesmos e do mundo que habitamos. Todo este movimento merece ser compreendido para que melhor habite seu espaço e seu tempo.

O corpo é percebido quando sinaliza falha no sistema que garante o seu funcionamento. A percepção do corpo atual, em geral, inicia-se com o vivenciar de uma experiência, podendo ser ela no âmbito físico ou no psíquico. Na verdade é como se o corpo chamasse a atenção da consciência por meio de um fato psicofísico. Na vivência dos fenômenos que ocorrem no seu corpo durante o climatério, as mulheres tendem a aterem-se nas modificações que afetam o seu ir e vir. Como o que se desvela na fala de Ártemis e Hera:

"Nesta idade é difícil [...] .passou dos 40 (anos) [...] você não consegue arrumar emprego e se consegue tem que segurar com unhas e dentes. Saber que a idade tem a ver com isso me incomoda. Quando a gente tá trabalhando esquece mais os problemas. Eu tenho muito 
medo da velhice. Não quero nem me imaginar enrugada. Eu sempre trabalhei [...] a gente quer ter as coisas da gente. Eu já tô na fase do envelhecimento [...] por dentro eu não tenho noção do que tá acontecendo.A gente muda e como muda!" (Ártemis)

"A gente magoa mais fácil, tem mais dificuldade de entender o que as pessoas falam. A percepção fica lenta, a gente fica mais dispersa. A gente esquece muito [...] coisas importantes que a gente não pode esquecer eu esqueço [...] não sei se é menopausa ou se é algum Alzheimer que vem por aí [...]." (Hera)

O corpo é ferramenta, mediador organizado entre o sujeito e o mundo. Ele é o espaço onde o fenômeno ocorre e, conforme citado anteriormente, ele não pode ser considerado apenas como uma reunião de órgãos justapostos no espaço, mas deve ser reconhecido por um esquema corporal em que os seus órgãos estão envolvidos. Esse esquema corporal não é simplesmente o resultado das associações estabelecidas no decorrer da experiência vivida. Ele é [...] dinâmico [...] é uma maneira de exprimir que meu corpo está no mundo [...]. De forma que o corpo se coloca em prontidão diante daquilo que tem por fazer. Sua espacialidade é de situação e não de posição. O corpo atende às demandas do mundo (Merleau-Ponty, 1999, p. $145,147)$.

Para exercer o seu papel no mundo, o corpo precisa instrumentalizar o Ser, permitir que realize seus propósitos. Quando este estado de prontidão do corpo deixa de existir, o sujeito vê inviabilizado o seu propósito de manter-se ativo, produtivo e participante do seu mundo.

No depoimento de Hera percebe-se uma sensação de frustração por sentir-se despojada dos atributos do corpo saudável e jovem transitando pelo espaço: 
"[...] esse negócio de a vida começa aos 40 (anos) não é bem assim não! Com 53 anos não tem muita coisa pra viver mais mesmo que você quer o seu corpo não agüenta [...]. Você põe uma pessoa aí de 30 anos para fazer um trabalho competitivo com uma igual por exemplo eu com 53 anos [...]!!! [...] quando a gente é mais novo acha que amanhã é outro dia e agora não é assim. A vida passa rápido demais de uma certa idade. [...] eu sempre fui muito ativa, trabalhava em dois empregos, sempre fui o homem e a mulher da casa. De repente, você sente aquela sensação de impotência! Você pegava isto e fazia com aquela velocidade! [...] amanhã você tem que fazer um pouco e depois outro pouco [...] isso gera uma frustração, eu não dou conta! Não estar trabalhando me causou uma tristeza muito grande [...]. Então eu procurei pôr outras coisas no lugar para mim não sentir falta. Quando você não pode trabalhar acha que tá realmente acabada [...] e você sabe que não depende de você [...] não existe mágica[...] O trabalho é uma felicidade! Você saber que cumpriu sua tarefa." (Hera)

Merleau-Ponty (1999) afirma que o espaço corporal é uma maneira de exprimir que meu corpo está no mundo. Ele é o fundo sobre o qual o corpo pode destacar-se, ou seja, o vazio diante do qual ele pode aparecer atuando e é na ação que a espacialidade do corpo se realiza. Nesse sentido, considerando o corpo em movimento, vê-se que ele habita o espaço e o tempo. O movimento assume o espaço e o tempo ativamente e em cada momento é preciso que saibamos onde está nosso corpo sem precisar procurá-lo, como buscamos um objeto retirado durante nossa ausência. É preciso que até os movimentos automáticos se anunciem à consciência, quer dizer, que nunca existam movimentos em si.

Percebo também que o corpo sempre seguirá o movimento da existência, pois mesmo que não se queira interagir com ele, o corpo está ali à espera do sujeito que dará a ele o sentido do movimento. O corpo está aí, pode ser encontrado pelos sentidos, palpado, visualizado e a consciência que habita o corpo é que Ihe doa vida.

Ser deve então habitar este corpo e, definitivamente, apropriar-se dele movendo-se em direção à sua plenitude e em relação aos outros seres e ao próprio mundo. 
Merleau-Ponty (1999) cita que mediante o corpo o Ser se vê no mundo. É preciso conservar a vida e o corpo Ihe empresta, de certa forma, os movimentos para direcioná-la. A experiência do corpo faz com que a mulher reconheça o que é seu e o que é universal, passando a ser o centro significativo que se comporta de certa maneira na própria existência.

O autor, acima citado, afirma ainda que o movimento não é o pensamento de um movimento, e o espaço corporal não é um espaço pensado ou representado. Executamos nosso movimento num espaço que não é vazio e sem relação com eles: movimento e fundo são apenas momentos artificialmente separados de um todo único.

Assim, se o nosso corpo não está no espaço, se ele habita o espaço e o tempo, podemos supor que no movimento de ir e vir, no decorrer da experiência vivida podemos apreender os significados de cada momento e isso o fazemos considerando o que somos. Se é pelo corpo que o sujeito identifica as suas limitações, é nele que ficam registradas as marcas do tempo, é ele que inicia o processo de interiorização da consciência por meio da vivência de uma situação de fato. No âmbito deste estudo, as falas das mulheres sinalizam que elas vivem num corpo que se modifica com o passar do tempo e que isto Ihes traz algumas inquietações, como pode ser observado nas falas citadas anteriormente.

No entanto, apesar das angústias, o importante é assumir este momento da vida, apreciando cada detalhe do movimento do corpo, durante o qual o instante precedente não é ignorado, mas está como que encaixado no presente, e a percepção presente que tenho do meu corpo consiste, em 
suma, em reaprender, apoiando-se na posição atual a série das posições anteriores que se envolvem umas às outras. É o passado ajudando a compor o presente com vistas no porvir.

Do contrário, a representação do corpo como invólucro violado, roto, perdido tomaria conta dos sentidos e o sujeito ver-se-ia encerrado em si mesmo, sem perspectivas e vislumbrando apenas o fim:

"Fico envergonhada de sair na rua [...] se você tá meio gordinha você não pode botar uma roupa que aparece a barriga [...] que marque muito que fica [...] desconfortável." (Tique)

"Na fase dos 46 aos 47 anos a angústia começou a aumentar. Algumas coisas no meu corpo começaram a mudar e eu não sabia o que era! É muito difícil você ser uma mulher ativa, ter brilho nos olhos, disposição e de repente perceber que está perdendo tudo! Além de perder a vontade de viver, você tá vendo seu corpo começar a enrugar. Eu não tenho medo de ficar velha, mas [...] eu tinha que aceitar a modificação devagar e não de uma só vez como foi. Se eu parar de tomar hormônio isso aqui (aponta para as mãos lisas) vai murchar como um maracujá." (Afrodite)

Os discursos das mulheres entrevistadas reforçou em mim a certeza de que se o sujeito se mantiver centrado nas limitações, nas deficiências corporais, será muito difícil ajudá-lo a compreender que o espaço e o tempo não são estanques em si mesmos, pois conforme citado por Merleau-Ponty (1999), enquanto tenho um corpo e por meio dele ajo no mundo, para mim o espaço e o tempo também não são uma soma de pontos justapostos e eu não estou no espaço e no tempo. Meu corpo aplica-se a eles e os abarca. Quanto mais eu apreender isso maior a amplitude da minha existência, mas de qualquer forma, a amplitude da existência nunca pode ser total, pois o espaço e o tempo que habito de todos os lados têm horizontes indeterminados que encerram outros pontos de vista. Dessa forma, a síntese 


\section{Unificações ontológicas}

do tempo, assim como a do espaço, está sempre para se recomeçar. O horizonte é infinito assim como as possibilidades do Ser também o são.

$\mathrm{Na}$ realidade, não existe fim e sim um processo de vivências encadeadas umas nas outras e todas numa única consciência.

Merleau-Ponty (1999) coloca que se olho uma casa antiga, ela tem um ar de eternidade - o tempo se dá como testemunha - Ela pode ser vista através de todos os tempos desde o momento de sua construção. Desse modo o presente tem na sua mão o passado imediato. Da mesma maneira, a mulher no climatério, apesar de seu presente conter o seu passado e o tempo a vir, já é um outro presente que opera diante daquilo que existe em seu mundo. O seu presente não apaga suas lembranças e seu futuro também não apagará o seu presente. A sua história é resultado de suas relações, seu tempo, entre todos os outros, é um reflexo ou um aspecto abstrato do tempo universal, no qual o seu corpo atua num espaço, que é ao mesmo tempo seu e do outro.

O corpo entra e sai de sintonia com o tempo e o espaço no sentido de dirigir-se, ter que fazer o movimento de vaivém da vida. Às vezes a mulher tem dificuldade em perceber em seu próprio tempo e espaço qual é o som do seu corpo, o que ele quer dizer-lhe, e assim poder mudar conscientemente a trajetória de sua vida. Para Merleau-Ponty (1999), não se deve dizer que nosso corpo está dentro do espaço, nem aliás que ele está dentro do tempo e sim que ele mora no espaço e no tempo.

Uma vez compreendido e situado no espaço e no tempo, mas não fixado a ele, o corpo segue vivendo suas experiências, incorporando 
vivências e percebe que há prazer em viver. Começa a compreender o movimento e refletir sobre ele. Por isso o corpo recebe mais um atributo: ser nosso meio geral de ter um mundo. Antes, entretanto, importa lembrar que só posso compreender a função do corpo vivo realizando-a, eu mesma, na medida em que sou um corpo em direção ao mundo. Nesta direção cabenos conquistar o prazer, cultivar a alegria e outros sentidos já que o corpo é o espaço de prazer, é o exercício da liberdade e recusar-se a priorizar áreas, espaços é recusar ao corpo a expressão do prazer (Merleau-Ponty, 1999).

Assim, a vida pode ser considerada um eterno fluir que vai deslizando lentamente, mas intrinsecamente voltada para o ciclo biológico e vital. Nesse sentido é desejável que a mulher acolha o seu Ser e o seu corpo diante da própria natureza. Podendo viver a vida a cada vez e a cada fase diferente, diferente do já conhecido, do antes, mas o diferente que gera vida.

Nesta fase do climatério, a mulher reflete também sobre a sua sexualidade. A vivência do prazer traz à tona toda a experiência que envolve este atributo do corpo. Assim sendo, os discursos das mulheres culminaram na próxima unificação ontológica apresentada a seguir:

\subsection{Refletindo sobre a sexualidade}

O tempo e o espaço são vividos e habitados concomitantemente por todos os seres que, invariavelmente, vivem em relação uns com os outros. 
Nesta inter-relação vivenciam o prazer e sentimentos que nutrem e retroalimentam a existência, sendo a experiência do prazer tão necessária quanto as outras funções orgânicas vitais (Freitas, 1999).

Merleau-Ponty (1999) concebe a afetividade, como um mosaico de estados afetivos, prazeres e dores fechados sobre si mesmos, que por vezes não se compreendem e só podem ser entendidos por meio da organização corporal. Daí vem as sensações e a afetividade pode ser reconhecia como um modo original de consciência. [...] É preciso que exista um Eros ou uma Libido que animem um mundo original, dêem valor ou significação sexuais aos estímulos exteriores e esbocem, para cada sujeito, o uso que fará de seu corpo objetivo [...] (p.215). A percepção erótica dá-se por meio de um corpo que visa a um outro corpo. Ela se forma num mundo e não numa consciência. Dessa maneira, a sexualidade trata de uma intencionalidade que segue o movimento geral da existência com poder da significação.

O termo sexualidade representa um conjunto de valores e práticas corporais culturalmente legitimadas na história da humanidade. Abrange não só a atividade sexual e sua dimensão biológica, mas diz respeito a uma dimensão íntima e relacional que compõe a subjetividade das pessoas e suas relações com seus pares e com o mundo. Envolve a percepção e controle do corpo; o exercício do prazer/desprazer, bem como os valores e comportamentos em processos afetivos e sexuais (Heilborn, 1999 apud Mandu, 2001). 


\section{Unificações ontológicas}

No ciclo biológico das mulheres tudo o que elas reconhecem sobre si é desvelado por meio da experiência no mundo mediante a historicidade. As mulheres atribuíram vários sentidos à sexualidade, ultrapassando barreiras e re-significando algumas "verdades" relacionadas à sexualidade e à qualidade de vida no climatério.

Para exercer a sexualidade, a mulher deve reconhecer o espaço corporal, o seu corpo agindo neste espaço e se fazendo presente no mundo e isto é possível de concretizar-se no encontro com o outro. É nesse encontro que ela percebe as diferenças entre si mesma e o outro, que aprende a distinguir as diferentes qualidades da relação com ele e consigo mesma, que pode descobrir o amor e o ódio, o prazer e a dor.

Viver a sexualidade pressupõe reconsiderar o nosso papel na existência humana e situá-la na origem dos sentimentos do ser-para-si e do ser-para-o-outro. Como afirma Merleau-Ponty (1999, p. 227-28) [...] No próprio instante em que vivo no mundo, em que me dedico aos meus projetos, a minhas ocupações, a meus amigos, a minhas recordações, posso fechar os olhos, estirar-me, escutar meu sangue que pulsa em meus ouvidos, fundir-me a um prazer ou a uma dor, encerrar-me nesta vida anônima que subentende a minha vida pessoal. Mas, justamente, porque pode fechar-se ao mundo, meu corpo é também aquilo que me abre ao mundo e nele me põe em situação.

$\mathrm{Na}$ busca por viver o prazer Tique trilhou caminhos de encontros e desencontros e revela: 
"Teve uma época [...] que eu tirei isso (o sexo) da minha vida por problemas que tive no primeiro casamento [...] depois que eu fui retomar a vida sexual. Então eu nunca fui de muita euforia, não; eu sempre fui mais pausada e [...] depois do climatério pode ter [...] eu fiquei mais pausada um pouquinho mais. Meu marido é uma pessoa bacana, é carinhoso [...] pode não ser no resto do dia, mas naquele momento ele faz tudo o que tem que ser feito [...] daí eu me empolgo [...] se não for assim eu não me empolgo". (Tique)

Apreendo da fala de Tique que o movimento da existência em direção ao outro, ao futuro e ao mundo pode começar a qualquer momento, assim como um rio degela. Posso reencontrar a razão da existência quando abrirme novamente ao outro, ao passado, quando deixar-me permear pela coexistência. Isso é sempre possível, pois mesmo absorvendo-me na experiência do meu corpo e na solidão das sensações não chegarei a suprimir a referência que tenho de minha vida em relação ao mundo. A cada instante alguma intenção brota novamente em mim. Por este motivo, refletir sobre a sexualidade e a vivência do prazer envolve a experiência do corpo e não somente de um momento específico (Merleau-Ponty, 1999).

Para esse autor, a existência corporal continuamente faz-nos a proposta de viver, é o esboço da nossa verdadeira presença no mundo e estar no mundo só faz sentido se temos o outro. Dessa forma, viver a sexualidade implica no reconhecimento de que o corpo do outro é dado a mim, como imediatamente presentes em meu campo, porém, em se tratando do outro, isso se dá a sua maneira. O outro está predestinado a mim como espelho de mim mesma, assim como o sou para ele.

Nessa embricação do outro em nós, de nós no outro, pode surgir um elã , algo que nos vincula fortemente um ao outro e que pode assumir uma conotação diferente, que vai além do relacionar-se usual; assume a * Arrebatamento súbito e efêmero; impulso (Ferreira, 1999). 
necessidade de satisfação do prazer sexual. Esta necessidade está latente em todos os indivíduos e em alguns momentos da vida, diante das fragilidades do corpo físico e das relações que estabelece com o outro, pode encontrar-se limitada e o indivíduo pode desejar esquivar-se do relacionamento afetivo/sexual. É o que se observa nas falas que se seguem:

"O sexo é normal. O meu marido fala que eu tô estranha e que eu não gosto dele. Meu marido já me judiou muito [...] até apanhar já apanhei. Agora eu não gosto mais dele. Eu tenho outro. A diferença tá no tratamento. A gente vive assim como dois irmãos." (Ártemis)

"O sexo passa a ser uma coisa que não conta na vida da gente. Não tem mais prazer. Os seios não têm mais aquela sensibilidade, nem ao toque, nem de jeito nenhum [...] por isso a parte sexual fica muito limitada [...] o que antes era uma fonte de prazer hoje é indiferente. Talvez seja isso que desilude as pessoas menopausadas. Quanto ao meu companheiro a gente se vê pouco. Ele vive na casa dele e eu na minha, então a gente não tem muitos atritos [...] eu acho que deve ser muito desconfortável viver na mesma casa com alguém, por exemplo: tá frio eu quero ficar com os pés descobertos e ele quer dormir coberto [...] ele tá sentindo frio, eu tô com calor [...] eu acho que deveria ser problema. Às vezes penso que eu queria um marido pra ir comigo no baile, mas já pensou aquele homem todo o dia ali?" (Hera)

"[...] eu não tenho mais desejo sexual! Que que eu faço da minha vida agora?! [...] não tô velha [...] e não quero ficar assim!" (Afrodite)

Percebo que a vivência da sexualidade pode ou não ser afetada pelos sintomas do climatério. O diferencial para a satisfação do prazer mútuo estará vinculado ao afeto, ao desejo de estar com o outro. No entanto, quando isso ocorre, a mulher busca conviver com o problema, conforme se observa nas falas de Hera e Deméter:

"Eu não sei explicar bem o porquê, mas é [...] na verdade deveria ser uma fase melhor pra mulher [...] às vezes é desconforto pelo ressecamento e também pela [...] assim [...] ela (a vagina) fica assim mais insensível. Não tem prazer nada. Quando toma hormônio é diferente. Ajuda muito! Mas sem hormônio?! Realmente não conta o sexo [...] é mais companheirismo." (Hera) 
"[...] como marido e mulher não me atrapalhou em nada [...]. Eu tive também [...] ressecamento [...]. Acho que umas três vezes eu senti isso na hora do relacionamento. Eu sentia assim seca, sabe? [...] mas não fiz nada e passou." (Deméter)

Se o exercício do prazer vincula-se à relação que se tem com o próprio corpo, com o outro e com o mundo, exercitar a sexualidade não é ter vida sexual ativa somente, é encontrar-se consigo mesmo, é sentir-se acompanhado, é ter o outro como presença viva, atuante, como ser-com-ooutro num ambiente afetuoso. Se assim for, as limitações físicas não serão entraves para o prazer de estar junto com o outro:

Atena e Deméter comentam:

"Eu nunca tive nada disso. A libido normal [...] sempre normal [...] então eu acho até estranho [...]. Sempre foi tudo muito normal pra mim. Quando vejo as pessoas contarem eu acho até meio estranho porque pra mim foi sempre tudo muito normal." (Atena)

"[...] eu sempre falei desde o início do meu casamento que o sexo é uma coisa muito bonita e muito gostosa, desde que faça com prazer e com amor. Não é uma coisa como se fosse arroz com feijão todo o dia e toda a hora [...]. Então eu acho que nesse ponto eu e meu marido se combina muito bem." (Deméter)

Expressar o afeto, o prazer só faz sentido quando assumimos a importância de outrem em nossa vida. É perceber que nós e outrem somos duas entradas para o mesmo Ser, cada uma acessível apenas a um de nós, aparecendo, entretanto, um para o outro como parte do mesmo Ser.

Incluir o outro em nossa vida significa abrirmo-nos para outra possibilidade de viver com qualidade. Então, viver com qualidade passa pela função do afeto, da libido em direção ao corpo denominado de "Eros". Sentir de outra forma é negar ao corpo viver em plenitude (Freitas, 1999; MerleauPonty, 1999). 
Reconhecendo mais esta aptidão do Ser: viver o Eros interno é expressar, por meio do corpo, a sexualidade.

Por outro lado, quanto à realização do prazer sexual, no caso da mulher climatérica, é importante lembrar que não é só no seu corpo que as limitações fazem-se sentir. No que se refere ao seu parceiro sexual, não se pode desconsiderar as suas condições físicas, pois, em geral, o homem encontra-se numa faixa etária em que os distúrbios da virilidade também são incidentes e, muitas vezes, justificados por algumas doenças crônicodegenerativas das quais é portador.

Considerando a atividade sexual em seu aspecto relacional, as mudanças da sexualidade masculina, geradas pelo processo de envelhecimento, só muito recentemente tornaram-se visíveis e dizíveis, com o advento do Viagra. Mas como esse medicamento resolve "todos" os problemas, mantém-se o mito de uma sexualidade masculina que pode ser tratada, ao passo que a sexualidade feminina não se resolve com tanta facilidade/praticidade. Isso reafirma a crença de que o desejo sexual masculino seja maior que o feminino e que, apesar da visibilidade dada à vida sexual e do mito de liberdade que a cerca, significados tradicionais e diferenças de gênero mantém-se durante o processo de envelhecimento (Kublikowski, 2001).

Outro fato é que a sexualidade feminina sempre esteve envolvida em mitos e tabus que acabam por sedimentar seu exercício no domínio do inconsciente coletivo a partir do momento em que esta prática se dá envolta 
em mistérios/pecados e preconceitos, o que dificulta o vivenciar da mesma (Biffi, 1991).

A mulher, muitas vezes, submete-se a relacionar-se sexualmente com seu parceiro sem que isso lhe proporcione satisfação:

"Tem que excitar bastante pra daí começar a ter interesse. Às vezes vou ter interesse pra não contrariar meu marido [...]. Eu acho que é desinteresse mesmo, sem motivação. É muito difícil me satisfazer com alguém. Seria bom pra mim se eu tivesse mais interesse, mas eu não sei se eu acho tão importante, porque eu não corro atrás. Eu me acomodei! Eu procuro evitar confusão. Infelizmente a mulher é assim [...] ela não quer rolo e ela se faz de interessada. Você fica se reprimindo a adolescência inteira pela educação que teve. Você se reprime de tudo." (Tique)

Em contrapartida, se estamos inseridos num contexto, para colocarmos em evidência a gênese do Ser para nós, é preciso considerar o nosso meio afetivo, sendo importante então salientar que quase sempre se concebe a afetividade como um mosaico de estados afetivos, prazeres e dores fechados em si mesmos que não se compreendem e só podem explicar-se por nossa organização corporal. O mundo objetivo cada vez toca menos diretamente no teclado dos estados afetivos "elementares", mas o valor continua a ser uma possibilidade permanente de prazer e de dor. Se não é na experiência do prazer e da dor, da qual não há nada a dizer, o sujeito define-se por seu poder de representação e a afetividade não é reconhecida como um modo original de consciência (Merleau-Ponty, 1999). Então, a mulher vive seus relacionamentos afetivos como se os corpos pudessem se falar apenas por meio do contato íntimo. Por esse motivo, não basta estar presente fisicamente num determinado momento, é preciso estar com o outro. Tique comenta: 
"Eu nunca fui uma pessoa que tinha necessidade tão grande de sexo. O marido fala: 'você tem que ir no médico [...]'. E eu fui. Eu sempre senti desconforto na penetração. Acho que não é desconforto [...] eu não acho tão prazeroso [...] não sei se é porque a gente vai perdendo a umidade. Eu tenho umidade [...]. Me causa desconforto não ter disposição, interesse. Um dia rola melhor, outro dia menos e assim vai [...]." (Tique)

Ao deparar-me com tal relato, passo a considerar que o exercício da sexualidade ultrapassa os limites do contato físico e da realização dos desejos, da libido. A mulher vivencia a atividade sexual como um atributo que deve ser cumprido para oferecer prazer ao outro e que, não necessariamente, envolve a reciprocidade. Entretanto, o feedback do prazer, que propicia a ambos os envolvidos a satisfação, o contentamento deve ser mútuo.

Não obstante, conforme afirma Kublikowski (2001), se a estima de si estiver rebaixada não adiantará a presença do outro porque a estima de si, alimentada somente pelo olhar do outro, não encontra reconhecimento, ou acredita não poder encontrar. Na meia-idade feminina, as mudanças corporais, quando associadas a uma diminuição da estima de si, podem levar a uma diminuição do desejo sexual, ou apesar da permanência do desejo, interferir no exercício da sexualidade.

Em sua vivência Afrodite enfatiza a importância da sexualidade e destaca que é preciso haver equilíbrio da relação de afeto entre os pares e a condição orgânica dos seus corpos. Ela reconhece estas limitações e busca soluções:

"Tive um casamento que não foi muito bom porque não existia o carinho necessário, mas criei três filhos maravilhosos, mas sempre envolta com um monte de probleminhas. A libido sumiu [...] fui no G.O. (ginecologista) de novo e falei pra ele: 'Dr. eu não tenho mais desejo 
sexual, o que eu faço da minha vida agora"? Não tô velha e não quero ficar assim [...] a minha mama tá parecendo uma bexiguinha dependurada, a minha genitália sumiu [...] o clitóris não sentia mais, tô sem secreção nenhuma, até a calcinha me machuca'. Nessas alturas tava muito desgostosa. Foi nessa época que meu relacionamento afetivo acabou. Daí eu fiz todos os exames e ele (o médico) me passou essa oitava maravilha que é a Tibolona. Voltou tudo! A libido tá saindo por tudo quanto é canto, voltou a vontade de viver, de me arrumar [...]." (Afrodite)

O discurso de Afrodite desvela que o corpo é objeto de prazer e que no exercício do prazer também é possível que o Ser sinta a importância do outro para si. Mas o que o difere dos outros animais é que a satisfação deste prazer não se encerra com o orgasmo. A vida sexual não pode ser circunscrita a um aparelho orgânico e não é pela vida sexual que se compreende a existência. $\mathrm{O}$ que dá sentido à vida é a possibilidade do compartilhar vivências, emoções, prazeres, alegrias e tristezas. A sexualidade não é um ciclo autônomo, mas está ligada interiormente ao Ser. Essa condição se expressa na fala de Atena:

"O relacionamento é normal como sempre. Não é de todos os dias, é uma coisa bem estudada. Nada me atrapalhou no sexo [...] eu e meu marido se combina muito bem. Agora esse ressecamento aconteceu e na hora do ato sexual eu senti mesmo." (Deméter)

Esse discurso denota que viver a sexualidade envolve uma imensidão de sentimentos. Estar com o outro, sentir o outro e compreender as múltiplas possibilidades do relacionamento. Kublikowski (2001) cita que a sexualidade não termina pela deficiência hormonal, mas se modifica na articulação de uma multiplicidade de fatores, interpretados em histórias individuais, de forma relacional, em determinado contexto e tempo.

No que se refere ao desconforto durante o ato sexual, ocasionados seja pela carência hormonal, seja ainda por problemas psicofísicos do parceiro, 


\section{Unificações ontológicas}

existem possibilidades de tratá-los/controlá-los. Já, a respeito do prazer de estar juntos, do desejo de compartilhar vivências e prazeres com o outro, como garanti-los senão reconhecendo-nos como sujeitos que estamos no caminho buscando resgatar-nos enquanto Ser? Como fazê-lo sem o outro?

Na vivência da sexualidade, muitas vezes, nos deparamos com crenças e valores que são extensivos à vida. Por exemplo: a necessidade que se tem de ficarmos sozinhos, às vezes, pode ser uma manifestação/expressão generalizada de um certo estado da sexualidade, de uma outra maneira de estar no mundo. Dessa forma, fazendo-se assim existência, a sexualidade assume uma significação tão geral que parece existir osmose entre a sexualidade e a existência, quer dizer, se a existência se difunde na sexualidade, reciprocamente a sexualidade se difunde na existência, de forma que é impossível determinar, para uma decisão ou para uma dada ação, a parte da motivação sexual e a parte das outras motivações. É impossível caracterizar uma decisão ou um ato como "sexual" ou "nãosexual" (Merleau-Ponty, 1999).

Este é o ir e vir da existência. É experienciar continuamente emoções, ganhos e perdas. Tudo isto é Existência.

Nesta trajetória, o Ser passa a perceber-se como corpo próprio e inicia um outro movimento por meio do qual a existência retoma e transforma uma situação de fato. O ser retoma o caminho buscando novas maneiras de coexistir no mundo, última unificação ontológica a ser apresentada. 


\subsection{Reconhecendo novas maneiras de co-existir no mundo}

[...] haverá sempre sentidos onde houver carne, e onde houver carne há história vivida, única e intransferível, pois será sempre resenha de toda ligação que eu tenho com o mundo e que transcende o refletido, pois mostra a dualidade do irrefletido [...]

(Merleau-Ponty apud Pokladeck, 2002, p.18)

Os fenômenos vividos pelo corpo podem sinalizar uma nova maneira de estar no mundo. Entretanto, o indivíduo pode ou não visualizá-los, buscar interpretá-los, descobrir-se. Esse movimento pode levá-lo a compreender-se como um Ser que está num mundo de relações consigo mesmo, com os outros e com o próprio mundo.

Optando por este caminho, seu corpo e o mundo deixam de ser objetos coordenados um ao outro por relações funcionais que a física estabelece. $\mathrm{O}$ corpo do indivíduo, então, é movimento em direção ao mundo e o mundo é ponto de apoio de seu corpo (Merleau-Ponty, 1999).

Na sua fala, Hera revê sua postura na relação consigo, com o outro e com o mundo em si:

"[...] hoje eu tô diferente com toda a certeza. Agora uma coisa que [...] isso aí tem pouco tempo pra cá. Não sei se tem a ver assim com a idade ou com a menopausa ou com a vida em si [...] mas assim [...] eu tenho notado que eu quero ficar mais em paz. [...] comigo mesmo e com as pessoas que faz parte da nossa vida. Porque antigamente [...]. Ah! Não gosta de mim? Problema!!!! (deu de ombros) Então hoje não! Eu não quero que a pessoa não gosta mais de mim. Antigamente eu não dava atenção a isso. Agora, hoje [...] eu quero viver mais em paz. Tanto com as pessoas quanto comigo mesmo. Porque a gente dessa vida não leva nada!" (Hera)

Merleau-Ponty (1999) comenta que o real é este meio em que cada coisa é, não apenas, inseparável das outras, mas de alguma maneira, 
sinônima das outras, em que os aspectos significam-se uns aos outros em uma equivalência absoluta. O real é a plenitude intransponível, ou seja, a coisa observada que só pode ser descrita considerando-se os seus significados. E, observando, é impossível descrever a cor de um tapete, de um tapete de lã, sem implicar nessa cor um certo valor tátil, um certo peso, uma certa resistência ao som. A coisa é este gênero de ser no qual a definição completa de um atributo exige a definição do sujeito inteiro e em que, por conseguinte, o sentido não se distingue da aparência total. Cézanne dizia ainda: "O desenho e a cor não são mais distintos; à medida que se pinta, se desenha, quanto mais a cor se harmoniza, mais o desenho precisa [...] quando a cor está em sua riqueza, a forma está em sua plenitude" (p. 433).

É apreendendo a sua existência que o Ser finalmente se encontra.

Nas falas que se seguem as mulheres fazem um movimento de olhar para sua vida e tiram conclusões, recuperam "pedaços" que antes talvez estivessem diluídos num todo complexo, resgatam sentimentos, enxergamse na própria vivência:

"Eu sou uma pessoa privilegiada. Eu tenho minhas filhas que me adoram [...] eu tenho saúde, tenho casa e isso é muito importante. Eu tenho tudo o que eu preciso pra viver." (Hera)

"Eu tô tendo mais vivência agora. Tô conseguindo dar um pouco de espaço pra mim também." (Tique)

"Eu sou feliz porque eu estou bem comigo, feliz com a vida. Eu lembro da menopausa quando eu falo. Eu tenho três netos e tô com 49 anos e mesmo com a menopausa eu nunca me senti velha." (Atena) 
"Cada um é cada um. Cada pessoa agüenta de uma forma. Tenho um marido maravilhoso, uns filhos maravilhosos!" (Deméter)

Quando vivo um processo intenso de mudanças e assumo que este processo pertence-me, que esta vida é minha vida, que tudo isto faz parte da minha constituição enquanto ser-no-mundo, coloco-me numa posição privilegiada, porque aproprio-me da minha existência, já que só posso perceber o mundo se, antes de serem fatos constatados, esse mundo e essa percepção forem pensamentos meus.

A percepção abre-me a um mundo e ao situar-me neste mundo tornome um Cogito* Corpóreo, ou seja, passo a reagir ao mundo intencionalmente e essa relação intencional entre mim e o mundo é produtora de significados. Então, saio da condição "penso, logo existo" e passo para a consciência de que "existo, existo no mundo e existo produzindo significados" (MerleauPonty, 1999; Josgrilberg, 2003).

Conforme Merleau-Ponty (1999), começo assim a perceber que a existência é um ato ou um fazer, e por ser um ato, por definição, é a passagem violenta daquilo que se visa, daquilo que se é àquilo que se tem a intenção de ser.

Ao encontrar-se vivenciando o climatério, assumindo-se, a mulher passa a ser um "em-si". Incorpora a sua vivência na sua completude de ser humano e vai ao encontro do mundo e de outrem, porque entende que eles são o prolongamento de si mesma. E ela o faz entrando em efervescência, como num grito que vem da alma, como a criança que respira pela primeira

\footnotetext{
* O Ser pensante.
} 
vez e ao mesmo tempo chora, abrindo os pulmões, acolhendo o sopro da vida:

"Eu tenho ódio é eles (filhas e genros) ligarem toda a hora no celular pra saber aonde eu tô. Não gosto que me ligue, me procure [...]. Aquilo me deixa irritada: o controle. Eu quero ficar em paz com as pessoas e comigo mesmo [...] quero pôr os pingos nos "is". Hoje eu lido diferente. Procuro fazer $50 \%$ pra ver se o outro faz 50\%, porque perfeito não existe ninguém. A gente tem que aprender a viver com as diferenças. A gente vai mudando." (Hera)

"Hoje eu modifiquei muito. Eu abri minha cabeça, eu enxergo as coisas de outra forma. Eu tô conseguindo dar um pouco de espaço pra mim também." (Tique)

"Hoje eu sei que a velhice fica aqui (aponta para a sua cabeça), mas o meu corpo [...] eu tinha que aceitar a modificação devagar [...] e não de uma vez como foi!!! Hoje eu me sinto bem [...] eu me acho bonita, gosto do meu corpo. A barriguinha tá aqui, mas não faz mal [...] eu consigo ter um bom relacionamento de mulher comigo mesma [...] meu lado hormonal tá controladinho [...] e eu não tô com medo de câncer, não, viu?! Eu não [...] eu tô aprendendo a viver. Das fases da minha vida esta é a melhor. Eu ganhei respeito muito maior dos meus pais e das pessoas que me cercam. [...] eu acho que de agora pra frente eu vou viver bem [...] tô comprando minha casa [...]. Hoje eu levanto o astral do outro, mas o meu também tá lá em cima. Eu me tornei uma profissional melhor, mais maleável [...] eu fui me descobrindo, fui conhecendo [...]. Durante minhas aulas eu posso falar, porque eu vivi. Quando você passa a saber o que você tem, você consegue se controlar. Hoje eu acredito que posso fazer tudo. A segunda adolescência é tudo o que um adolescente quer: [...] eu catei minhas coisas, botei no carro, saí no meio de um surto [...] aquela angústia, aquela coisa [...] mas feliz! Como se eu tivesse quebrando um par de correntes. Fui embora! Hoje eu me sinto vitoriosa e apaixonada [...] não é uma coisa linda?!" (Afrodite)

"Eu sempre fui muito pra cima [...] eu só lembro da menopausa e da minha idade quando eu falo sobre isso [...] eu sou de bem com a vida." (Atena)

"[...] hoje eu trabalho bem o problema da menopausa, porque já acostumei a levar a vida conforme uma pessoa menopausada tem que ser. E vivo bem." (Hera)

Ser encontra na própria vivência a sua essência e sente que algo em

si se move rumo à sua consolidação. Diante disso é possível observar que, mesmo se pretendo compreender meu passado melhor do que ele se compreende a si mesmo, ele sempre pode recusar meu juízo presente e encerrar-me em sua evidência autista. Cada presente pode pretender fixar minha vida, é isso que o define como presente. Enquanto o presente se faz 
passar pela totalidade do Ser e preenche um instante de consciência, eu nunca liberto-me dele inteiramente. $O$ tempo nunca se fecha inteiramente com o presente (Merleau-Ponty, 1999).

No entanto, a vivência do climatério não está no tempo e no espaço e nem fora deles. O tempo e o espaço se estendem para além dela. Essa experiência deve ser assumida para que possa ser vista do meio dela mesma e daí alcançar compreendê-la já que, para tornar-se visível, o corpo deve ser tomado do meio de questões/problemas que, aparentemente, podem ser inquestionáveis ou naturais. Essa é a oportunidade que o indivíduo deve aproveitar para que, finalmente, possa apropriar-se de si mesmo.

Quando se pretende ver a "coisa" (a vivência), deve-se saber que não será possível vê-la, a não ser que se deixe ser possuído por ela, pois é na espessura do seu corpo que o Ser encontra o meio para chegar ao âmago das coisas, fazendo-se mundo e fazendo-as carne (Merleau-Ponty, 2003).

Esse autor enfatiza que é unicamente o corpo que pode levar-nos às próprias coisas, ao ser-em-si. Este ser-em-si não é um ser plano, mas em profundidade, inacessível àquele que o sobrevoe e só aberto para aquele que com ele coexista no mesmo mundo.

Para encontrar a sua essência, o seu Ser, a sua alma, seja como for denominado essa parte que vivifica o homem, faz-se necessário entender que não é na superfície do corpo próprio, mas na sua profundidade, que a essência situa-se. 
Dessa forma, buscar transcender o corpo exige que o Ser saia do círculo vicioso do tempo por ele mesmo. O passado, o presente e o futuro não são momentos estanques e não podem ser analisados como pedaços de uma existência. Do contrário, o Ser não encontrará caminhos que possam the oferecer a possibilidade de agregar as vivências tidas ao longo do tempo e projetar o seu futuro.

Merleau-Ponty (1999) afirma que nossos poderes sobre o passado e sobre o futuro são escorregadios, a posse do tempo é sempre adiada até o momento em que nos compreendermos inteiramente, e este momento não pode chegar, pois ele ainda seria um momento, circundado por um horizonte de porvir, e que por sua vez precisaria de desenvolvimento para ser compreendido. Então é certo que o corpo é no mundo, ancora o Ser no mundo e o mundo é o ponto de apoio do corpo. No mundo vive-se o passado, o presente e o futuro.

Nas falas que se seguem nota-se que a mulher procura no passado a explicação para o momento atual e quando se refere ao futuro limita-o à corporalidade. Dá-nos a impressão de que a vida olhada no tempo traz sentimentos como angústia, falta de esperança:

\footnotetext{
"Você começa a pensar quem você foi. Depois de certa idade olha muito pro passado, não olha pro presente [...] não existe presente [...] e aquilo começa a gerar desesperança, porque nada daquilo vai voltar. Pra mim o futuro é esperar meus netos crescer. Na verdade não existe futuro. Quando a gente é novo acha que amanhã é outro dia e agora não é bem assim. Você valoriza muito o hoje. A vida passa muito rápido depois de uma certa idade, então o que você tem que fazer é hoje. Não tem muito tempo pra amanhã, não sabe se vai ter amanhã." (Hera)
}

"Eu não gosto muito de retornar ao passado. Meu tempo de infância foi bom. Se eu ficar sentada vou pensar em coisas passadas e eu não gosto de pensar. Eu me ocupo [...] não sei se é pra fugir dos problemas. É uma forma de fugir de si mesma." (Tique) 
Entretanto, compreendendo sua vivência, o sujeito pode também perceber-se diferente, já não se sente a mesma, como na fala que se segue:

"Você sabe que eu mudei muito. Eu não sou mais aquela 'a' (refere-se a seu nome no diminutivo) [...]. Hoje quando me chamam de 'a' eu volto lá no passado [...] e vejo o quanto eu mudei!" (Afrodite)

Para essas mulheres o viver hoje, ocupar-se, parece remetê-las à vida, mas é importante entender que o ontem e o amanhã também se manifestam no agora e o modo como a pessoa cuida de si pode dirigir o seu futuro e isso vai expandindo suas capacidades e relações consigo mesma, com o outro e com o mundo. Se ficar somente projetando coisas sem construir outras possibilidades do existir, isso repercutirá em novos conflitos existenciais, relacionados com o corpo-mundo.

Segundo Merleau-Ponty (2003), o Ser não pode ser contemplado de fora e na simultaneidade do passado, do presente e do futuro. A sua existência ao ser apreciada deve ser percorrida e, nesse ato de olhar e ver as etapas passadas, não se pode vê-las simplesmente como um trecho da estrada por onde se passou, mas como um momento vivido que exigiu para si as etapas presentes exatamente no que elas têm de novo e desconcertante, o que pode ser evidenciado na seguinte fala:

"Eu aprendi a entrar na minha casa e gostar de ficar comigo. Agora eu tô me dando melhor com meus filhos, meu ex-marido, com meu pai e minha mãe. Eu me tornei uma pessoa melhor. Agora tá tudo em cima, tenho brilho no olho, tô apaixonada. Eu me descobri sexualmente. Eu sou especial. Eu tô saudável pra encarar essa minha terceira idade que vai ser daqui mais ou menos 15 anos [...] pra que quando eu chegar lá eu possa estar tranqüila." (Afrodite) 
Não se trata de uma trajetória pela qual o Ser segue uma rota préestabelecida, mas sim de uma reflexão que abre várias possibilidades, na qual encontra-se a si próprio, avançando, provando a viabilidade do caminho, percorrendo-o incessantemente.

Merleau-Ponty (1999) enfatiza que estamos misturados ao mundo e aos outros em uma confusão inextricável e, nesse envolvimento, já não gozamos da liberdade absoluta e a cada momento a existência se faz sob nossos olhos, na nossa presença e pede sempre para ser recomeçada sem, no entanto, suprimir nossa finitude. De tal forma que, assumindo o presente, retomo e transformo meu passado, mudo seu sentido, libero-me dele, desembaraço-me dele. Se, ao contrário, procurar ultrapassar minha situação natural e social, recusando-me a assumi-la, deixarei a liberdade escapar e não a usarei para encontrar o meu mundo natural e humano. É certo que não precisamos temer que nossas escolhas ou nossas ações restrinjam nossa liberdade, já que, apenas elas, podem nos libertar de nossas âncoras.

Para o filósofo, é sendo o que sou e re-significando a cada momento a minha história é que consigo acessar ao mundo. Sendo, sem restrições nem reservas, aquilo que sou presentemente tenho a oportunidade de progredir. É vivendo meu tempo que posso compreender os outros tempos, é me entranhando no presente e no mundo, assumindo resolutamente aquilo que sou por acaso, querendo aquilo que quero, fazendo aquilo que faço, que posso ir além. Ele afirma ainda que, na relação com o outro podemos ser elemento facilitador para a sua transformação. Coexistindo com ele, ajudando-o a re-viver o seu passado, dando-Ihe significados. 
Mesmo numa situação específica, como no caso da vivência do climatério, é desejável que cada mulher não perca o significado de sua infância, adolescência e vida adulta para compor a maneira singular de vivenciar a sua totalidade como mulher. Despertando na adolescência, amadurecendo enquanto adulta a fim de reverenciar sua história na velhice. Isto consiste em compor a sua história no decorrer da sua trajetória na experiência corporal.

“ [...] Madura! Hoje eu tô bem! É a segunda adolescência e o bom é que quando você é adolescente pela primeira vez você não tem respostas. Na segunda adolescência você encontra as respostas, você é mais você! Eu posso sair, sou dona do meu nariz, posso surtar quantas vezes eu quiser, porque sou eu que me sustento [...]." (Afrodite)

Nesse sentido, concordo com Critelli (2005) quando afirma que o nosso nascimento é o começo da nossa história. Por meio dele somos lançados ao mundo com um corpo, um sexo, uma família, um nome, uma condição social, um país, uma época. O sentido ou o rumo da nossa vida já veio, de alguma forma, envolvida nele. Não ganhamos o fim da história, que só virá com a morte, mas ganhamos o início e uma certa bagagem para seguir o caminho.

A autora ressalta ainda que, quando compreendemos essa história, podemos agir sobre ela. Observando o caminho que temos trilhado e a forma como temos respondido aos acontecimentos que vêm ao nosso encontro, podemos encontrar a chave para construirmos a narrativa da nossa história. Não podemos modificar os eventos da vida, mas podemos alterar os modos de vivê-los. Então, quando somos capazes de compor o nosso vivido, estamos a ponto de ter a plena posse de nós mesmos. 
Apreciando o discurso das mulheres sobre a vivência do climatério e, instrumentalizada pelas lentes do referencial filosófico de Maurice MerleauPonty, compreendo que a existência é o movimento por meio do qual a mulher retoma o seu vivido, apropria-se dele e o transforma. Aprendi que a temporalidade e a espacialidade devem ser consideradas em todos os âmbitos de nossa vida, visto que não se trata de um momento e de um espaço específicos, estáticos, mas um continuum, um movimento da existência. Importante ressaltar que, a despeito da temporalidade, a validade dos achados permanece, pois a nossa memória se apóia em uma imensa memória do mundo, onde o objeto se mostra tal como ele verdadeiramente era naquele dia em que foi apreciado. Seu presente não apaga seu passado, seu futuro não apagará seu presente.

Partindo dessa nova compreensão do existir, torna-se imprescindível que se decida o que se quer ser. O Ser das coisas pelas coisas ou o Ser que sabe de si, que se ancora no mundo e por meio do seu corpo se faz existir. O ser-para-si, o ser-em-si, o ser-para-o-outro e, todos, no mundo.

Faz-se necessário abrir a janela do quarto escuro e deixar a luz entrar, de forma que deixando de apenas tatear as coisas, possa, agora, escolher o que quero tocar, o que quero mudar de lugar. Jogar luz para que possa contemplar a vida e isso posso fazê-lo de algumas formas, seja analisando e apontando erros e acertos aqui e acolá, seja apreciando os fatos vividos como alguém que quer saber de si. Posso observá-lo como se estivesse diante de uma obra de arte e, sendo o seu autor, sentir-me livre para mudar os tons, acentuar as cores, destacar um ou outro aspecto. 
Creio que seja imprescindível retomar a noção do corpo enquanto arquivo do vivido e, focando-o neste prisma, manifesto o meu pensamento, subsidiada pelo que apreendi ao desvelar o fenômeno ser mulher vivenciando o climatério. Aproprio-me deste conhecimento para ver, primeiramente a mim mesma enquanto mulher, mãe, irmã de outras mulheres, esposa e, posteriormente, ao outro, de forma a propor um novo caminho para atuar, enquanto enfermeira e docente de enfermagem. 
A borboleta liberta, voa solta, a toa, por aí [...] Enebriada pela seiva das energias evolui incerta, lúdica, em dúvidas fragmentada. Mas sempre pousa lúcida, aqui e ali, desperta, atualizada, embebida pelo néctar das existências!

Parece errante, distante, ausente mesma, de si [...] No entanto é bela, completa, brilhante. Vive no alimento do instante, desprendida, em constante transformação.

[...] E nos momentos em que a vida é clausura sob o jugo dos elementos, toma da agulha do tempo nos sete ciclos do clima etéreo, e tece, no casulo da noite escura, com a linha do conhecimento, seu futuro corpo de luz [...]

E permanece presente, transcendida, consciente, ciente do próprio Ser $[\ldots]$

E quando o calor do sol levante de nascente realeza Revela sua natureza de sonho; Ei-la, movida por insuspeitável leveza, mutante e única, translúcida e mágica, espalhando no Firmamento o pó da sabedoria!

Abre asas borboleta!

Levanta vôo!

Viver um dia é pouco Mas é muito no existir [...]

(A.C. Velloso, junho/2005) 


\section{DELINEANDO MODOS DE CUIDAR DA MULHER NO CLIMATÉRIO}

[...] Tu habitas em teu próprio ato. Teu ato é tu [...]. Tu te transformas [...]. Tua significação se mostra, ofuscante. Este é teu dever, é tua raiva, é teu amor, é tua fidelidade, é tua invenção [...].

O homem é só um laço de relações, apenas as relações contam para o homem. (Maurice Merleau-Ponty, 1999, p. 612)

No meu dia-a-dia enquanto mulher posso perceber as mudanças, não só em meu próprio corpo, como também na forma de lidar com os acontecimentos da vida, nas preferências quanto ao estilo de vida ideal, os relacionamentos interpessoais, enfim. Sinto-me vivendo uma outra fase na qual os valores passam a ser reavaliados, por vezes substituídos e/ou fortalecidos. É como se o caminhar só fizesse sentido, porque estou irremediavelmente vinculada aos outros: familiares, amigos, colegas de trabalho e demais pessoas do meu círculo de relacionamentos.

Os fatos vividos, ao longo da minha existência, ganham novos significados e fortalecem o meu Ser, ajudando a reafirmar meus propósitos de vida.

Enquanto enfermeira é possível melhor compreender as manifestações/expressões daqueles que estão sob meus cuidados e dos que comigo partilham o fazer diário do trabalho. É como se meu corpo tivesse adquirido maior aptidão para enxergar aquilo que se apresenta aos meus olhos, enquanto gestos/atitudes, que também portam muitos outros 
sentidos, além do ir e vir dos corpos. Sinto-me mais amadurecida para aceitar os meus limites e os dos outros e buscar novos caminhos.

Entendo que a Enfermagem é uma prática que se consolidou no fazer, no cuidar. Entretanto, passamos muito tempo priorizando o desenvolvimento da habilidade, da destreza, do raciocínio e julgamento clínicos, do domínio de novas tecnologias para o cuidar e, nem sempre, aceitamos as opções/desejos dos que estão sob nossos cuidados, principalmente quando esses divergem das nossas intenções. Por esse motivo, creio que precisamos superar essas nossas limitações quanto à verdadeira aceitação e respeito pelo outro. Só assim estaremos cuidando e interferindo no modo de ser das pessoas de forma libertadora, que é aquela na qual o homem é entregue à sua própria transparência e responsabilidade para ser livre para si.

Esta minha postura é fortalecida pela ontologia de Merleau-Ponty, pois ela permeia o mundo da mulher naquilo que é percebido e vivido mediante o corpo, por tudo que nele se manifesta envolvido numa teia de relações.

Pensar sobre a mulher vivenciando o climatério como um ser-no-mundo e perceber que sua história se entrelaça à minha, pela cumplicidade de uma experiência, que não me é estranha, já que posso reconhecer as percepções do corpo-próprio, permitiu-me apropriar de um novo modo de ser-e-estar-nomundo-com-o-outro.

A sensação de estranheza e de familiaridade com o corpo é uma condição do ser-para-si, pois, em certos momentos, o mesmo corpo revelase com múltiplas formas de ser, e ao olhá-lo, percebe-se que se está longe 
de defini-lo ou descrevê-lo, pois ele é desconhecido e abstrato, simultaneamente. Isso se deve à sua condição de inseparabilidade daquilo que vive com aquilo que manifesta ser em seu corpo-próprio.

Considero que a possibilidade de viver a reciprocidade se concretiza no fazer do cotidiano, nas relações que estabeleço com o mundo e com os outros. Dessa forma, acredito que, enquanto ser existindo num mundo de relações, necessito compreender os limites impostos ao corpo-objeto, que, enquanto carne está fadado à finitude, mas, por essência, também está destinado a perpetuar-se.

Nesta pesquisa pude perceber que a mulher climatérica vive uma situação que é explicitada pela evolução natural do corpo-próprio e, para compreender as suas manifestações no cotidiano, é preciso considerar que, ao longo dos anos, esta mulher trilhou os caminhos da história com novas descobertas, algumas revolucionárias, que provocaram transformações profundas em sua maneira de conceber e viver o climatério. Nesse percurso ela passou da atenção de algo tão inovador, no conceito de beleza do passado, como o batom para a busca por um modelo corporal estereotipado, que ia da gordura passiva da belle époque à magreza ativa do século vinte, o que perdura até os dias atuais.

Desse modo, a mulher foi aos poucos conquistando espaços na sociedade, mas ainda continua submetida a novos padrões de imagem corporal, incorporando, entre outros, os ideais da eterna juventude.

Nesta trajetória histórica, algumas questões ficaram por serem respondidas, por exemplo: Como aceitar o envelhecimento sem senti-lo 
como sinônimo de perda? Como se desvencilhar da tríade beleza-juventudesaúde, se aprendemos que a beleza do corpo é a nossa juventude; a sua juventude é a nossa saúde e a sua saúde é a nossa beleza?

É muito difícil à mulher enfrentar a situação de perda de sua juventude, mesmo que isso tenha uma explicação científica, porém, o sentimento de perda aparece no próprio corpo que aos poucos vai se ajustando ao novo jeito de se manifestar no mundo. A mulher vai aprendendo a acomodar-se aos limites físicos advindos de sua transformação ao vivenciar o climatério. Desse modo, aprender a viver num corpo que se transforma rumo à terceira idade pode significar um quase renascer e até mesmo um processo de acolhimento ou chance de recomeçar, carregando na memória muitas lembranças e emoções, que poderão ajudar a sustentar uma nova etapa de sua evolução.

Creio que, uma das possibilidades seja assumir as limitações impostas pelas mudanças corporais, tornando-nos conscientes de que elas fazem parte da evolução natural do indivíduo e que são ferramentas que a mulher possui para amadurecer e crescer enquanto Ser, e para isso deve estar consciente que um dos primeiros passos para superar esses limites é assumir a responsabilidade de cuidar de si mesma.

O lugar, por vezes, forçosamente, ocupado pela mulher nos meios de produção e na família, embora ainda condicionado pelo jogo do poder sócioeconômico e político, pela desigualdade de gênero e pelos seus próprios valores, coloca-a numa condição mais propícia para assumir-se e buscar pela qualidade de vida. 
Retomo a idéia de que os diversos climatérios da existência corporal das mulheres são os motores que as impulsionam pela vida e as trazem a todo o momento para o presente. Mesmo que, às vezes, algumas mulheres demorem a reagir e ajudar-se de alguma forma, como trabalhar e cuidar do corpo. Com a longevidade, além dos limites impostos pelo tempo, também se valorizou as atividades físicas acopladas às recomendações de hábitos de vida saudáveis, complementadas pela conquista de novas tecnologias que trouxeram outras opções como a Terapia de Reposição Hormonal.

A TRH é um tema de pesquisa que recebe, a cada dia, maior atenção da comunidade científica e das próprias mulheres que desejam dela fazer uso. Novas formulações prometem oferecer alívio para alguns sintomas do climatério com menores riscos para saúde da mulher.

O acesso aos recursos, embora pouco democratizado em função da pauperização da sociedade, encontra-se disponível, bastando que se organize o meio para sua obtenção, ou seja, que o Programa de Atenção Integral à Saúde da Mulher, no que se refere ao climatério, seja efetivamente implementado.

$\mathrm{Na}$ realidade, muitos profissionais da saúde expressam essa necessidade, mas poucos se envolvem e se comprometem com essa questão quando se faz referência à saúde da mulher no climatério. Usualmente a atenção é ressaltada para outras fases do ciclo reprodutivo, como o pré-natal e o parto.

Merleau-Ponty refere o sujeito no mundo como corpo e a consciência como encarnada no corpo. Desse modo, a mulher, ao vivenciar o climatério 
vai adquirindo a consciência de seu novo corpo mediante suas percepções e experiências até transformar isso em conhecimento para então estabelecer prioridades e assumir novos modos de vida.

Entretanto, antes de a mulher ter essa consciência e almejar um nível satisfatório de saúde, por meio de atividades e hábitos de vida saudáveis, ela deve ser incentivada. A prática da dança, da natação, da yoga, as caminhadas diárias, por tempo e freqüência recomendados, podem e devem ser utilizadas como aliadas nesta fase da vida. Cabe aos profissionais da saúde participarem desse trabalho junto às mulheres, a fim de que possam ser motivadas para aderirem e sustentarem um novo modo de se autocuidar.

A ênfase no tratamento e controle das doenças crônico-degenerativas, como a Hipertensão Arterial Sistêmica e o Diabetes Mellito; na abolição do tabagismo e etilismo; no consumo de alimentos ricos em cálcio e proteínas e hipogordurosos; na valorização da auto-estima das mulheres climatéricas, deve ser incentivada, bem como a compreensão de que os limites impostos ao corpo sempre existiram e sempre estarão presentes para auxiliar-nos a expandir os nossos horizontes, adaptando-nos aos novos e incessantes processos existenciais.

Os construtos teóricos sobre a temática e os preceitos da Fenomenologia Existencial reafirmam a minha visão holocentrada na mulher que vivencia mais um, dentre todos os outros momentos da sua vida, e ancoram minha postura pessoal e profissional numa perspectiva que considera o corpo como portador de percepções e intencionalidades. 
Acredito que este Ser, pode trazer consigo o sentido de certeza de si, que é a origem da sua própria existência e pode, então, re-significar o próprio corpo, o seu espaço, o seu tempo, o seu mundo e a sua liberdade. Mediante o corpo a mulher toma consciência de si em seu existir no climatério, buscando uma nova maneira de relacionar-se com o mundo.

Essa premissa, presente neste estudo, permitiu-me compreender o Ser Mulher na sua complexidade, o que foi possível pelo que apreendi dos seus relatos, sobre a vivência do climatério e dos significados que atribui a esta experiência de vida. Isso tudo teve uma dimensão fundamental para pensar qual a responsabilidade de quem ensina, pela maneira como elabora e trabalha a questão do climatério, e de quem cuida da mulher nesse período de vida.

Da mesma forma os profissionais, que trabalham diretamente com a assistência à mulher, devem repensar como isso vem ocorrendo. Talvez seja necessário "desconstruir" o conceito de climatério como síndrome da falência ovariana e "reconstrú́-lo" como sinônimo de um processo complexo de vivências, no qual a mulher passa por transformações que abrangem aspectos fisiológicos, mas também psíquicos, social e cultural, bem como seus valores.

Apenas criticar o que vem acontecendo no cenário da saúde não ajuda. Re-conceituar o significado de saúde-doença pode sim levar os profissionais de saúde, tanto aqueles que trabalham na prática como na academia, a desenvolverem um saber outro, reconhecendo o processo natural e social em que a mulher encontra-se inserida. Dando condições e possibilidades 
para que esta mulher, que está no climatério, possa vivenciar essa etapa de sua vida de forma mais natural e singular possível.

Desse modo, torna-se possível que esses profissionais consigam superar algumas limitações atendendo às demandas das mulheres climatéricas, uma vez que passam a compreender que o cuidar da mulher neste estado pressupõe estar junto a ela, para poder deparar-se com suas necessidades e assumir o cuidado circunscrito pelo modo que a mulher vivencia o seu cotidiano.

Essa forma de cuidar tem a ver com a Enfermagem, pois é imprescindível que o enfermeiro, junto à equipe de enfermagem, re-pense suas ações e as implemente na prática, visando à primazia da vida, seja na recuperação da saúde ou no âmbito da prevenção das doenças. Dessa maneira, deve auxiliar as mulheres em todas as fases do seu ciclo vital valorizando o cuidado de forma que elas, com a ajuda dos profissionais, possam melhor se conhecer e assumir o cuidado de si mesmas. Com isso pode surgir um novo caminho a ser desvelado no trabalho da enfermagem abarcando a educação.

Que no desempenho das atividades educativas, o enfermeiro atue enquanto membro de uma equipe multidisciplinar e, após ter despojado-se dos pré-conceitos adquiridos, estabeleça uma relação mais autêntica, de forma que sendo-com-o-outro possa compartilhar saberes, anseios, dúvidas, sentimentos e emoções, num processo de coexistência que se dá numa relação horizontal, em que o indivíduo é valorizado e motivado a refletir sobre seu modo de vida e seus limites. Assim, torna-se possível permitir que 
as mulheres reflitam sobre as alternativas de novos caminhos em busca de uma convivência melhor consigo mesmas e com seus pares.

No âmbito do ensino de enfermagem, será preciso envidar esforços para incluirmos temas e novas metodologias de ensino, que privilegie a interconexão da razão com a sensibilidade, de forma que o profissional seja formado com a visão da complexidade e da subjetividade. Que os programas vinculados à saúde da mulher não enfatizem somente as doenças. Que se possa conhecer o corpo da mulher em todos os seus ciclos de vida envolvidos em seus processos vividos, em relação a si mesma, com o outro e com o mundo em que se encontra inserida.

O profissional de enfermagem necessita compreender que não detém todo o saber e que suas ações, junto à mulher no climatério, somente serão justificadas se forem implementadas, respeitando o modo de ser mulher em seu cotidiano, em seu espaço e tempo.

Vale ressaltar que isso é um desafio para a enfermagem, uma vez que a filosofia dos serviços de saúde e das instituições de ensino dá visibilidade a um possível risco dos profissionais implementarem formas de cuidar e de ensinar, respectivamente, que podem ofuscar a autonomia dos pacientes/clientes que são sujeitos principais da sua atenção.

No exercício da investigação científica, paralelo às pesquisas que envolvem biotecnologias com finalidades de atender aos aspectos objetivos/práticos e mensuráveis dos processos de saúde-doença, é importante que sejam desenvolvidos estudos com vistas ao desvelamento 
de outros fenômenos da vivência do climatério, respaldados pelos princípios científicos que possam apontar novos caminhos para o cuidar.

Urge a implementação do trabalho multi, inter e transdisciplinar, tanto no ensino, quanto na assistência e na pesquisa. Entretanto, mais do que debater sobre programas assistenciais e formação de profissionais da área da saúde, as pessoas carecem de despertar para a prática da solidariedade, o reconhecimento da subjetividade, da intuição, da emoção, dos sentimentos que movem o homem no mundo na direção da auto-realização, da plenitude enquanto ser-no-mundo, resgatando o sentido do humano em cada um.

Assim sendo, cabe aqui selar um compromisso que advém de múltiplas experiências em relação ao cuidar. Sei que na área da docência há muitos desdobramentos a fazer em relação ao cuidado da mulher no climatério, que devem ser olhados e compreendidos por vários ângulos, pois não se pode considerar que o atendimento das demandas dessas mulheres estará resolvido somente por escutá-las. É preciso aproximar-se cada vez mais do que é real diante de diferentes situações, construindo uma interconexão entre os muitos feixes de percepção e aquilo que nos é dado como evidência, considerando o que é sentido e vivenciado na própria existência de cada mulher.

Em verdade, a Fenomenologia Existencial ajudou-me a rever o contexto de significados e das referências que tinha sobre a mulher no climatério, enquanto algo característico do ser-mulher. No sentido do meu próprio vivenciar como mulher posso re-significar a minha existência, para ser-com-o-outro, e assim perceber que as mulheres podem deixar agir em 
si-mesmas o modo de ser de Ártemis, Hera, Tique, Afrodite, Héstia, Deméter e Atena que trazem em si essências de suas vivências do climatério, em conformidade com aquilo que é concebido como presente em seu mundo em conjunção com o mundo de outras mulheres. 


\section{REFERÊNCIAS BIBLIOGRÁFICAS}

Abdo CHN, Fonseca AM, Bagnoli VR, Canaes KR, Vitoria SM, Neto FRA. Perfil sexual da mulher no climatério. Rev Ginecol Obstet 1997; 8(1):37-9.

Abraham S, Llewellyn-Jones D, Perz J. Changes in Australian women's perception of the menopause and menopausal symptoms before and after the climacteric. Maturitas 1995; 20(2/3):121-8.

Aldrighi JM, Hueb CK, Aldrighi APS. Climatério. RBM Rev Bras Med 2000; 57(n esp):209-15.

Anderson D, Yoshikawa T, Gollschewski S, Atogami F, Courtney M. Relationship between menopausal symptoms and menopausal status in Australian and Japanese women: preliminary analysis. Nurs Health Sci 2004; 6(3):173-80.

Appolinário JC, Coutinho N, Povoa LC, Meirelles R. Terapia hormonal e os sintomas psíquicos na menopausa. J Bras Psiquiatr 1995; 44(4 Pt 1):169-76.

Appolinário JC. A depressão na menopausa: uma entidade específica? Inf Psiquiatr 1999; 18(4):107-14.

Appolinário JC, Meirelles RMR, Coutinho W, Povoa LC. Associação entre traços de personalidade e sintomas depressivos em mulheres com síndrome do climatério. Arq Bras Endocrinol Metab 2001; 45(4):383-9.

Banister EM. Women's midlife confusion: "Why am I feeling this way?". Issues Mental Health Nurs 2000; 21(8):745-64.

Beauvoir S. O segundo sexo: a experiência vivida. Trad. de Sérgio Milliet. $2^{\mathrm{a}}$ ed. Rio de Janeiro: Nova Fronteira; 1980. Da maturidade à velhice; cap. 5, p. 343-62.

Biffi EFA. O fenômeno menopausa: uma perspectiva de compreensão. [dissertação]. Ribeirão Preto (SP): Escola de Enfermagem de Ribeirão Preto/USP; 1991.

Bortoletto CCR, Baracat EC, Gonçalves WJ, Lima GR. Aspectos reprodutivos da mulher climatérica. Femina 1999; 27(3):215-8. 
Brown PF. Other ways of growing old: anthropological perspectives. Med Anthropol Q 1983; 14(3):18-9.

Bruns MAT. Reflexões acerca do "fazer" metodológico. In: Castro DSP, organizador. Fenomenologia e análise do existir. São Paulo: Universidade Metodista de São Paulo/ Sobraphe; 2000. p. 215-24.

Buchanan MC, Villagran MM, Ragan SL. Women, menopause, and (Mis) information: communication about the climacteric. Health Commun 2001; 14(1):99-119.

Candella CLM, Ruggiero CM, Araya MES, Silva RV. Assistência de enfermagem à mulher no climatério. Rev Esc Enferm USP 1995; 29(1):4758.

Capalbo C. Abordando a enfermagem a partir da fenomenologia. Rev Enferm UERJ 1994a; 2(1):70-6.

Capalbo C. Considerações sobre o método fenomenológico e a enfermagem. Rev Enferm UERJ 1994b; 2(2):192-7.

Capalbo C. A fenomenologia a partir de Edmund Husserl e sua repercussão na área da saúde. Rev .Enferm UERJ 1998; 6(2):415-9.

Capalbo C. Fenomenologia e ciência: Edmund Husserl e Maurice MerleauPonty. In: Castro DSP, organizador. Existência e saúde. São Paulo: Universidade Metodista de São Paulo; 2002. p. 13-34.

Capalbo C. Corpo e existência na Filosofia de Maurice Merleau-Ponty. In: Castro DSP, organizador. Corpo e existência. São Bernardo do Campo: Universidade Metodista de São Paulo/FENPEC; 2003. p. 11-23.

Cousins SOB, Edwards K. Alice in menopauseland: the jabberwocky of a medicalized middle age. Health Care Women Int 2002; 23(4):325-43.

Crema R. Saúde e plenitude: um caminho para o ser. São Paulo: Summus; 1995.

Critelli D. O sentido da vida e a história pessoal. Folha de São Paulo [Encarte] 2005 abr 21; Folha Equilíbrio, p. 2.

Cunha F. Climatério: uma visão holística. Femina 1993; 21(1):63-4.

Daoud IG. Encontros e desencontros das mulheres climatéricas que buscam assistência em serviço do Sistema Único de Saúde. Rev Enferm UERJ 2002; 10(1):33-7. 
Dartigues A. O que é fenomenologia. São Paulo: Moraes; 1992.

Favarato MECS, Aldrighi JM, Fráguas Junior R, Pires ALR, Lima SMRR. Sexualidade e climatério: influência de fatores biológicos, psicológicos e sócio-culturais. Reprod Clim 2000; 15(4):199-202.

Ferreira ABH. Novo Aurélio: o dicionário da Língua Portuguesa - Séc. XXI. São Paulo: Nova Fronteira/Lexikon Informática; 1999. [CD-ROM].

Forghieri YC. Psicologia fenomenológica: fundamentos, método e pesquisas. São Paulo: Pioneira; 1993.

Freitas MEA. A consciência do corpo - vivência que assusta: a percepção de profissionais de Enfermagem na área hospitalar. [tese]. São Paulo (SP): Escola de Enfermagem da USP; 1999.

Goldfarb DC. Corpo, tempo e envelhecimento. São Paulo: Casa do Psicólogo; 1998.

Gonçalves R. Transformar-se enquanto mulher: um estudo de caso sobre a vivência do período pós-parto. [dissertação]. São Paulo (SP): Escola de Enfermagem da USP; 2000.

Greer G. Mulher: maturidade e mudança. São Paulo: Augustus; 1994.

Haines CJ, Rong L, Chung TKH, Leung DHY. The perception of the menopause and the climacteric among women in Hong Kong and southern China. Prev Med 1995; 24(3):245-8.

Halbe HW, Fonseca AM, Bagnoli VR, Borato MG, Ramos LO, Lopes CMC. Epidemiologia do climatério. Sinopse Ginecol Obstet 2002; (2):36-9

Jiménez López J, Peres Silva GP. Actitud de la mujer en la menopausia y su influencia en el climatério. Ginecol Obstet Mex 1999; 67:319-22.

Josgrilberg RS. O método fenomenológico e as ciências humanas. In: Castro DSP, organizador. Fenomenologia e análise do existir. São Paulo: Universidade Metodista de São Paulo/Sobraphe; 2000. p. 75-93.

Josgrilberg RS. Fenomenologia: Maurice Merleau-Ponty. [aula ministrada no Programa de Pós-Graduação - doutorado - EEUSP - 09 de outubro de 2003].

Kublikowski I. A meia idade feminina em seus significados: o olhar da complexidade. [tese]. São Paulo (SP): Pontifícia Universidade Católica de São Paulo; 2001. 
Landerdahl MC. Mulher climatérica: uma abordagem necessária ao nível da atenção básica. Nursing 2002; 5(47):20-5. (edição brasileira).

Lima CP, Lopes GP, Brendler J, Lima RP. Sexualidade e climatério. Femina 2002; 30(8):577-8.

Lock M. Menopause: lessons from antropology. Psychosom Med 1998; 60(4):410-19.

Lugones Botel M, Valdés Sánchez S, Pérez Piñero J. Climaterio, familia y sexualidade. Rev Cubana Med Gen Integr 1999; 15(2):134-9.

Mandu ENT. Adolescência: saúde, sexualidade e reprodução. In: Associação Brasileira de Enfermagem (ABEn). Projeto Acolher: adolescer, compreender, atuar, acolher. Brasília: ABEn/Ministério da Saúde; 2001. p. 61-74.

Martins J, Bicudo MAV. A pesquisa qualitativa em psicologia: fundamentos e recursos básicos. São Paulo: Moraes/Ed. PUC-SP; 1989.

Merighi MAB. A docência de enfermagem em uma universidade pública: um enfoque fenomenológico. [tese]. São Paulo (SP): Escola de Enfermagem da USP; 1993.

Merleau-Ponty M. Fenomenologia da percepção. São Paulo: Martins Fontes; 1999.

Merleau-Ponty M. O visível e o invisível. São Paulo: Perspectiva; 2003. (Coleção Debates).

Navarro Despaigne DN, Fontaine Semanat Y. Síndrome climaterico: su repercussion social en mujeres de edad mediana. Rev Cubana Med Gen Integr 2001; 17(2):169-76.

Neco GPB, Sá MRC, Castilho DW. Proposta cinesioterápica no tratamento da mulher climatérica. Femina 1995; 23(3):266-7.

North American Menopause Society (NAMS). Clinical challenges of perimenopause: consensus opinion of the North American Menopause Society. Menopause [serial online] 2000; 7(1):5-13. Available from: <http://www.menopause.org > (31 maio 2003).

North American Menopause Society (NAMS). Menopause Core Curriculum Study Guide. Pte. A. Introduction. [on line]. Available from: http://www.menopause.org (31 maio 2003).

Pedro AO, Pinto-Neto AM, Costa-Paiva L, Osis MJ, Hardy E. Procura de serviço médico por mulheres climatéricas brasileiras. Rev Saúde Pública 2002; 36(4):484-90. 
Pelcastre-Villafuerte B, Garrido-Latorre F. Menopausia: representaciones sociales y prácticas. Salud Publica Mex 2001; 43(5):408-14.

Penteado SRL, Fonseca AM, Bagnoli VR, Abdo CHN. Sexualidade no climatério e na senilidade. Rev Ginecol Obstet 2000; 11(3):188-92.

Pinto-Neto AM, Pedro AO, Costa-Paiva LHS, Maia CAT, Vieira MJN, Lima Júnior JAT et al. Repercussões biopsicossociais da transição climatérica: a visão da mulher. J Bras Ginecol 1994; 104(9):307-10.

Pokladek DD. Cuidar do humano: experiências terapêuticas e seus sentidos existenciais. Santo André: Alpharrabio; 2002.

Ribeiro Junior J. Fenomenologia. São Paulo: Pancast; 1991.

Rousseau ME. Women's midlife health: reframing menopause. J Nurse Midwifery 1998; 43(3):208-23.

Sand G. Está quente aqui ou sou eu? Um exame pessoal dos fatos, equívocos e sensações da menopausa. São Paulo: Summus; 1995.

Sant'Anna DB. Corpos de passagem: ensaios sobre a subjetividade contemporânea. São Paulo: Estação Liberdade; 2001. Notas sobre peso e velocidade dos corpos; p. 13-28.

Scalco MZ. Depressão e menopausa. Femina 2002; 30(1):51-5.

Schraiber LB. Pesquisa qualitativa em saúde: reflexões metodológicas do relato oral e produção de narrativas em estudo sobre a profissão médica. Rev Saúde Pública 1995; 29(1):63-74.

Secco LM. Mulher e Sexualidade: estudo realizado a partir das deusas mitológicas. Rev Terapia Sexual Clin - Pesquisa e Aspectos Psicossociais 2002; 5(1):41-62.

Souza CL, Aldrighi JM. Sono e climatério. Reprod Clim 2001; 16(1):20-5.

Stephanides M. Os Deuses do Olimpo. São Paulo: Odysseus; 2004.

Stepke FL. Las ciencias sociales como discurso de la salud reproductiva. El ejemplo del climatérico femenino. Cad Saúde Pública 1998; 14(Supl 1):1314.

Velazco Murillo V, Navarrete Hernández E, Ojedas Mijares RI, Pozos Cavanzo JL, Caramacho Rodríguez MLA, Cordona Pérez JA. Experiencias y conocimientos sobre climaterio y menopausia en mujeres de la ciudad de México. Gac Med Mex 2000; 136(6):555-64. 
Vieira EM. A medicalização do corpo feminino. Rio de Janeiro: Fiocruz; 2002.

Zahar SEV, Aldrighi JM, Tostes MA, Russomano F, Zahar LO. Avaliação da qualidade de vida na menopausa. Reprod Clim 2001; 16(3):163-6. 


\section{ANEXOS}

\section{ANEXO A \\ DEPOIMENTOS}

\section{DISCURSO 1}

\section{ÁRTEMIS (Deusa da noite}

enluarada dos bosques e da caça)

51 anos, casada, dois filhos; profissão: cozinheira (desempregada). Ártemis é bem extrovertida e alegre. Fez questão de garantir nossa privacidade. Fez questão de levar-me na casa da filha, que morava ao lado, e mostrar-me sua neta.

Pra mim não tá fazendo diferença nenhuma por que graças à Deus eu não sinto nada. A única coisa que eu sinto é o calor mas eu tomo remédio... é normal. Às vezes tem dia que eu me sinto assim meio triste. É uma sensação estranha. Não sei se é como fala mesmo ... é... com depressão... e eu penso: eu nunca fui assim porque que agora eu vou... eu vou ficar né? Aí eu começo... eu ligo o rádio, eu canto, vou na casa da minha filha, minha neta vem aqui e nós dá risada, eu brinco, falo besteira e pronto, aí passa. Se a gente for pôr na cabeça isso aí... ai meu Deus... do céu... eu triste.... Eu não ponho isto na minha cabeça não de jeito nenhum! Eu não sei te responder por que isto aparece na minha cabeça assim (risos...) Eu acho que a minha vida não mudou 
em nada sobre isto aí... sobre a menopausa. Por que tem gente que tem dor de cabeça, sente isso e sente aquilo... minha vida é normal. O sexo é normal... No íntimo nada mudou. A única coisa que me atrapalha é esse calor. No começo, nossa! Eu dormia pelada no chão. Eu sentia um calor sabe? Um calor que vem de dentro assim pra fora parece que vai até estufar o olho da gente de tanto calor que a gente sente. A única coisa que eu acho cruel é isso aí. Agora eu tô fazendo tratamento e aí $80 \%$ diminuiu... mas eu continuo tomando remédio. Eu fiz sete tipo de exame e nenhum deles não deu nada, nada, nada. Todo ano eu faço prevenção, faço o exame de diabetes, colesterol, papanicolau e não deu nada graças a Deus. A única coisa que eu vou falar pra você... é o calor!!! Sobre a tristeza, a depressão... eu acho que tem a ver com a menopausa porque antes eu não tinha nada disso. Sabe antes eu caía na cama e dormia que nem uma pedra. Agora, tem dia que eu acordo às vezes 1 e 1/2, 2 horas, 4 e 5 horas da manhã eu tô acordada. E sabe... aquele calor... eu me descubro... sinto frio, sinto calor... um suor... parece que eu entrei embaixo do chuveiro. No começo minha filha falava assim: Nossa mãe o que que é isso? Sabe pingava assim o suor. Nossa! Mas é um calor muito cruel. Eu não desejo que nem uma mulher passe por esse calor que a gente tem que passar. Eu não durmo. Olha... às vezes eu acordo e nem o calor tá tão forte.É só você sentir assim uma coisa diferente você já acorda e arranca o cobertor. Se eu tô de blusa de manga comprida eu tiro e 
fico sem blusa só com a calça do pijama. O calor é só daqui pra cima (aponta para a parte do tronco) e no pé. Eu pego o travesseiro e me abano e me abano... e aí passa... e quando ele (o calor) tá ameaçando voltar eu já acordo. Tudo isto na mesma noite. Quando eu trabalhava à noite então!!! Ichi!!! É na cozinha que é quente né?! E vinha aquele calor assim que dava vontade de tirara a roupa... aí eu saía lá fora. A gente fica vermelha que nem um camarão. Fica vermelha mesmo! A minha colega que trabalhava comigo falava: Ô G. por que você tá tão vermelha? Eu dizia: É esse calor que parece que vai me matar. Quando eu menstruava eu já tinha isso. Quando eu entrei nos 44, 45 anos eu já tinha esse calor mas era pouquinho. Depois que as menstruações acabaram piorou.
Principalmente 0 ano passado. No ano passado eu fiquei onze meses sem menstruar aí a médica pediu um ultrassom vaginal pra ver se eu ainda ia menstruar e aí ela disse: "um ovário seu ainda tá funcionando. Você vai menstruar e não vai demorar muito!" Mesmo assim ainda demorou um pouco. Eu menstruei ainda uma vez só e depois não menstruei mais.

Fale-me mais sobre essa sensação estranha.

Ah! eu acho que.... (risos, abaixou o olhar e olhou pela janela...) Ah! eu num falo nada não! Às vezes me dá vontade assim de ir embora! Largar tudo!! Eu acho que devido a isso aí!!!

Vem do nada. Às vezes eu sinto uma tristeza tão grande que até minha filha percebe e aquela vontade de chorar. Aí eu choro. Eu 
acho que é a menopausa porque antes eu não tinha isso. Quando vem a vontade de largar tudo e ir embora eu resolvo sozinha. Fico pra mim sozinha. Eu não sou de me abrir com ninguém não! Eu mesmo resolvo sozinha. $\mathrm{O}$ meu marido fala que eu tô estranha e que eu não gosto dele... essas bobeiras... Se ele começa a falar me dá vontade de chorar aí ele fala: Eu hein!!! Mulher quando entra na "menô" fica assim!!! (risos...)

\section{E o que você pensa sobre isto?}

É que eu não tenho como explicar! Como que eu vou explicar porque que eu estou assim???? A M. (a filha) pergunta: mas porque que a senhora está assim?? Eu digo: eu não sei!! Eu não sei se é por que eu me preocupo muito. Eu já tô há 8 meses sem trabalhar. Nesta idade é difícil... Olha! Você passou dos 40 (anos) você não consegue arrumar mais emprego e se você consegue arrumar vpcê tem que segurar com unhas e dentes porque tá difícil. Saber que a idade tem a ver com isso me incomoda... não só pra mim como pra todo mundo. Meu marido mesmo tem mais de 8 anos que meu marido não trabalha fichado... é só fazendo bico!!! E agora ele já tá com 59 anos e já...sem chance... Eu graças a Deus... corro atrás... mando currículo e graças a Deus eu entrei pela pela agência (agência de emprego) e terça feira já começo a trabalhar, graças à Deus. E... sabe... quando a gente tá trabalhando esquece mais dos problemas. Eu tenho um casal de filhos já moços. Meu caçula faz 30 anos o mês que vem... (risos). 
Tenho 3 netos e eu adoro meus netos, graças à Deus!!!

Então... penso na idade... bate cansaço... você se olha no espelho ... aquelas ruguinhas que já vão aparecendo (risos)... ai meu Deus... (risos). Olha eu vou te falar a verdade...eu tenho muito medo da velhice não pela idade... as rugas... ai!!! Eu não quero nem me imaginar enrugada. Eu olho no espelho e penso que quando eu tinha uns... uns 30 anos... nossa!!! Eu era bonita!! A gente muda tanto!! Se você vê uma foto minha quando eu tinha 16 anos e vê agora!! Nossa Senhora!!! Como muda... muda muito!! Eu sempre prestei atenção nisso. Você acredita??!! Eu e a minha irmã a gente tem muito medo da velhice. A gente é muito vaidosa. Tenho medo de ficar doente e dependente dos outros e os filhos colocar a gente num asilo. Eu sempre peço à Deus pra não me jogar em cima de uma cama por que senão eu acho que eu vou morrer muito rápido. Eu nunca dependi nada.. nada... nada...nem de marido nem de filho... nem pra me dar uma calcinha. Eu tenho 31 anos de casada. Se eu falar que o meu marido me deu alguma coisa... foi esse relógio... (mostra o punho com o relógio). Eu sempre trabalhei... ele me conheceu trabalhando e sabe... eu me sinto mal ficar em casa. Graças à Deus a gente quer ter as coisas da gente e não quer depender de ninguém.

Eu acho que os sintomas da menopausa não são iguais para todas as mulheres. A minha irmã mais velha tem osteoporose e vive com dor de cabeça... a minha irmã vive doente... a minha irmã 
nossa!!! A minha irmã não tem saúde depois que entrou na menopausa. Agora eu graças à Deus tenho disposição pra trabalhar. Eu sou diferente dela porque eu não sinto nada. Ela sente dor nas pernas e muita dor de cabeça. Ela tem esse negócio de osteoporose que eu não tenho. Até agora eu não tenho nada disso de dor... de nada. Às vezes meu genro fala assim... por que eu tenho uma netinha né?! Ele fala: Essa daí (a neta) puxou a vó... tem uma saúde de ferro... Graças à Deus!!!

Eu já sofri muito! Meu marido já me judiou muito... até apanhar já apanhei! Agora eu não gosto mais dele. Quando ele me toca sabe?! Eu sinto... nojo!!! (faz cara de Nojo). Eu tenho outro. Com o outro é diferente. A diferença tá no tratamento... no carinho. A gente tem que ter carinho... se ele (o marido) não fosse assim até que... a gente vive assim como dois irmãos. A gente dorme na mesma cama. A gente tolera isso por causa dos filhos. Eu já tentei resolver isto mas... agora eu não penso mais... Eu tenho minha casa. Eu batalhei tanto pra ter isto aqui!!! $\mathrm{E}$ eu não deixaria de mão beijada. Ele (o marido) não tem pra onde ir e não adianta falar pra ele ir embora. Pra onde ele vai? Ele é pai dos meus filhos!!

A G. (ela mesma) é a mesma só muda só as rugas... Sobre a menô (menopausa) no começo eu dormia no chão. Eu tirava a roupa. Tem um colchão ali debaixo da cama. Eu puxava ele e dormia nele sem cobertor e com ventilador!! (risos... muitos risos...) Eu tirava a blusa e ficava só de shortinho, abria a porta de vidro 
pra tomar ar... falava prá ele (o marido) fica aí!!!

Eu todo dia quando vou deitar eu não sou crente... os crente ora né?!... Eu rezo!!! Eu peço muito pra Deus me dar muita saúde, pra tirar esses calor de mim. Os remédios que eu tomo agora eu parei né?! É muito caro!!!! Faz uma semana que acabou... 20 comprimidos sai 44 reais... eu tomo um por dia... mas quando é remédio preparado o calor passa mais rápido. Os preparados são mais baratos... mas aí eu ainda não mandei fazer... Se você quiser ver o nome dos remédios... acho que é climadil... Eu pedi pra médica passar aquele que manda preparar O climadil é o mais caro e vai passando devagar... antes era 32 reais... foi para 39 e agora 44 reais...
Só que eu acho também que eu associo essas tristeza à esta fase... porque antes eu não tinha nada disso. Quando eu namorava ele me dizia que eu ria muito... até hoje qualquer coisa eu dô risada. A idade vai chegando e as coisas não são mais como eram antes... e a gente vai tá rindo porquê??? Antes a gente era jovem... podia rir mais... Que nem a roupa... eu gostava de roupa decotada. Agora não dá mais. A gente vai chegando numa certa idade e não me sinto bem usar roupa decotada. Não sei por que. Não fica bem pela idade da gente por que você sabe como é... os outros julgam muito... ah! Uma velha usando roupa decotada!!! Eu uso blusa de alcinha porque eu me sinto bem mas usar roupa como eu usava antes... uns 20 anos atrás eu não tenho mais coragem! 
Porque o meu corpo mudou! Ôpa!!

E como!!! Eu pesava 48 quilos. Até uns 35 anos eu pesava 48 quilos. Aí você entra na menopausa e a tendência é engordar. Sabe com quantos quilos eu tô agora??? Tô com 75 quilos e tudo isto por causa do quê??? Da menopausa. A menopausa faz a gente engordar. Não é só o calor que me incomoda. A gordurinha também! Eu não tinha... eu tinha um corpinho bonitinho. Lembra?! $\mathrm{Na}$ época usava aquele macacão bem decotado assim... agora... com essas gordurinhas caindo do lado... Deus me livre. Sabe por quê? Eu vejo os outros também... as mulheradas com essas banhas caídas... De calcinha e mini blusa... e como eu reparo os outros também reparam. Tem cada moça aí que usa bermuda e as banhas... Eu vou te mostrar... (vai buscar fotos para eu ver). Nessa foto é quando eu tinha 16 anos.... (risos....)... Esses dois aí (na foto) aponta... são meus dois irmãos... um já morreu!!! (faz expressão de tristeza!!!). Aí tá vendo como meu corpo era bonitinho. Eu acho que eu já tô na fase do envelhecimento. Passou dos 48, 50 anos eu acho que... olha... que às vezes que tem colega minha que tem a minha idade ou até mais nova que aparenta mais velha que eu. Às vezes falam: Nossa nem parece que você tem 52 anos! Eu falo pra elas: olha aqui os pezinhos de galinha aparecendo. Elas falam que pela idade que eu tenho não aparenta. Eu acho que não é a mesma coisa. A gente muda. E como muda!!! O corpo a gente vê toda a hora.... as gordorinhas, a barriga... Eu sou um pouquinho 
vaidosa. Eu já uso creme pra passar na barriga, eu tomo remédio pra emagrecer. Mas não consigo!!! Eu não consigo e eu não como muito. Eu não consigo emagrecer. Eu queria chegar pelo ao menos aos 63 quilos mas eu não consigo. $E$ isso tem e muito a ver com a menô. Quando eu tinha 28 anos eu vivia tomando remédio pra engordar. Eu queria ter mais bunda... Meu chefe falava assim pra mim: $G$ não fica tomando vitamina... agora vc é nova e quando ficar mais velha você vai começar a engordar. Aí quando eu cheguei com uns 35 anos, 36 anos eu já comecei dar umas engordadinhas... aí depois dos 40 desembestou. Por dentro eu não tenho noção do que tá acontecendo. Acho que eu nunca parei pra pensar sobre isto não. Depois que chega uma certa idade começa a aparecer verruga no corpo da gente (e levanta a roupa e começa a mostrar). Começa aparecer aquelas manchas... Eu fui no dermatologista e falei: Olha doutor isso aqui são células mortas... Ele disse: Que células mortas o quê!!! Ele passou remédio que deixou pior... ficou branco... isso é preocupante... $\mathrm{E}$ outra coisa também... quando eu fui no oculista... o meu grau tá aumentando. Eu falei: Nossa!!! Uma vista ta com 2,5 e a outra ta com 2,0. Eu falei: Nossa doutor, cada vez que eu venho aqui aumenta o grau!!! Ele falou: Ah! É a idade.... (risos). Falei pra ele: Então quando eu tiver com 60 anos eu vou ta cega???!!! Ele disse: Também não é bem assim!!! Chega um certo tempo que pára né?! É!! A idade vai chegando e a gente fica com a vista fraca Isso 
não abalou porque tem ... óculos né?!!! (risos, muitos risos!!!) Nem tudo tá perdido. Ele (o médico) disse que não vou chegar a ficar cega. Ele disse que eu já sou casada, já tenho filhos e que tudo isso vai influenciando.

A minha mãe fala também que quando a gente tá de dieta (pósparto) a gente tem que cuidar mais. A gente anda descalça, meche com água fria na dieta. E quando chega uma certa idade isso vai pesar. Não é só eu que digo isso não. Não é só minha mãe. Eu concordo. Eu acho que quando a gente ta de dieta a gente quando chega à tarde tem que tomar seu banho, pôr uma calça comprida. Porque a gente tem que prevenir a saúde da gente agora... pra depois a gente não sofrer as conseqüências....

\section{DISCURSO 2}

HERA (Esposa de Zeus. Rainha do céu e protetora do casamento e das mulheres):

53 anos, viúva, duas filhas, profissão: técnica de enfermagem (aposentada). Hera é um pouco introvertida mas após garantir a privacidade da conversa foi bastante enfática nos seu discurso. Aparente uma certa melancolia e postura rígida consigo mesma e com seus familiares. Em alguns momentos evidenciava poucas perspectivas de vida, desanimada.

Hoje eu vivo bem. Eu tive problemas no início da menopausa que era o fogacho, a irritação, o ressecamento vaginal, a insônia... eu tive muitos problemas... depressão. Quando eu comecei tomar hormônio eu comecei sentir 
super bem. Minha indisposição era total e comecei a sentir muito bem mas com os debates que eu fui observando que poderia causar o câncer e na minha família tem a predisposição eu resolvi parar de tomar. Hoje eu trabalho bem o problema da menopausa porque já acostumei a levar a vida conforme uma pessoa menopausada tem que ser. E vivo bem.

Para você, como é que uma pessoa menopausada tem que ser?

Ela vive assim: um dia bem humorada outro dia mal humorada (risos). Isso já faz parte. Então um dia eu tô bem humorada, outro dia to mal humorada é... sem disposição pra qualquer coisa, não quero conversar e outro dia tô feliz da vida como já fizesse mesmo parte da vida. Eu procuro conviver da melhor maneira possível que é uma coisa que eu vou ter que conviver pro resto dos meus dias. Não adianta eu tentar modificar que vai ser assim. Tenho problemas, às vezes, de... é... como fala assim... aquela desesperança total da vida que a gente pensa que não resta mais nada! Que eu já tô acabada. Aí eu penso: Puxa vida! Mas eu não tô acabada não! Pois eu vejo que tem tanta gente... aí eu olho pras outras pessoas mais velhas que eu e vejo que tá cheia de vida e parece que aquilo dá uma injeção de ânimo na gente. Mas assim... o sexo passa a ser uma coisa já que não conta na vida da gente. Eu tenho companheiro. Eu tenho desconforto vaginal. Eu acho que não é só isso não. Eu não sei explicar bem o porquê mas é na verdade deveria ser uma fase 
melhor pra mulher... às vezes é desconforto pelo ressecamento e também pela assim... ela (a vagina) fica assim mais insensível. Não tem prazer nada. Quando toma hormônio é diferente. Ajuda muito! Mas sem hormônio?! Realmente não conta o sexo... é mais companheirismo.

Você pode falar mais sobre essa sensação de desesperança, depressão. Como é isso pra você?

Essa tristeza a gente não sabe de onde vêm. Ela vem parece que é da alma mesmo! Porque você talvez começa pensar quem você foi... você fica olhando muito pro passado. A gente depois de uma certa idade olha muito pro passado. Você não olha pro presente. Porque na verdade não existe muito o presente. Então a gente olha muito pro passado e aquilo ali começa a gerar uma desesperança porque você sabe que nada daquilo vai voltar. Que nada na vida volta mas só que você pensa assim: se hoje você tem 20 anos você tem muita coisa ainda pra viver mas por exemplo com 53 anos não tem muita coisa que viver mais. Por mais que fala: Ah! a vida começa aos 40 eu acho que não é verdade não! Esse negócio de a vida começar aos 40 não é bem assim não! É não começa aos 40 não porque mesmo que você quer o seu corpo não agüenta. Seu corpo não agüenta porque... pensa bem, você põe uma pessoa aí de 30 anos pra fazer um trabalho competitivo com uma igual por exemplo eu, com 53 ... são vários problemas que além da menopausa que gera esse 
desconforto eu tenho osteoporose e eu tenho... eu já sei que tem comprovado nos meus exames. Eu tive uma fratura no tornozelo que foi o que acarretou a minha aposentadoria. Então... assim... são muitos problemas que a menopausa traz! Então tem que ser uma coisa assim muito bem trabalhada e a gente era muito sem esclarecimento. Hoje talvez não aconteça com as mulheres que vão começar a entrar (na menopausa) que é a partir dos 40 e poucos anos ... porque tem mais esclarecimento... a mídia divulga. No tempo da gente não podia nem falar nessas coisas que era tudo muito reservado. Então eu acredito que para as próximas as coisas vão ser melhor do que pra gente tá sendo.

Eu acho! Por que vão trabalhando mais os hormônios, né?... tirando um pouco da química que pode fazer esse câncer conforme falam que... vai saber se é verdade ou não? Então, como eu já disse, como na minha família já tem (câncer) eu não quero pagar pra ver. Mas eu acredito que para as próximas gerações a indústria pode desenvolver um medicamento com menos riscos... exatamente menos riscos... é o que todo mundo espera porque se realmente ele faz esse mal é preferível que a gente tenha uma velhice é... que não seja lá tão confortável mas pelo menos sem esse risco. Eu acho que pra mim vale a pena eu ficar sem o hormônio, ter essa vida menos ativa igual eu tenho do que correr o risco do câncer.

Prá mim o futuro o que que é? É esperar meus netos crescer acompanhar eles. Pra mim na 
verdade não existe (o futuro). Não sei se eu sou... Eu conheço pessoas até mais velhas que eu que tem uma vida bem mais ativa que a minha. Talvez acho que varia de pessoa pra pessoa. Eu sou uma pessoa assim muito caseira, muito família, muito ali centrada na minha família. Então talvez seja isso que me tira um pouco da esperança porque se fosse uma pessoa assim que passeasse, tivesse mais... poderia ser assim que vivesse assim melhor. Eu acho que a gente tem que ser a gente. Eu não gosto de viver de representação.

Olha, eu acho que na verdade eu não sou infeliz não. Isso eu sinto com todas as letras que eu não sou infeliz, mas eu acho que a felicidade é uma coisa que a pessoa cria. Acho que isso não existe mesmo assim não! Acho que felicidade é assim: hoje você ta... você agora tá e daqui dez minutos você pode não tá tão feliz e isso principalmente na menopausa não precisa motivos pra pessoa ficar infeliz. Não precisa acontecer nada. Eu sinto que às vezes eu tenho tudo pra tá feliz e não tô! Às vezes nem tão ruim as coisas estão e eu tô feliz sorrindo e dando risadas. Então eu acho que varia... o nosso humor depende dos hormônios na medida que meche muito com a gente. Mesmo porque se a gente for olhar só por esse lado assim do hormônio... começar pensar você vai ver que muita coisa não tem a ver porque tem gente que tá com os hormônios tudo legal ali e é super mal humorado então eu acho que varia mesmo de pessoa pra pessoa. Acho o ritmo de vida minha saudável. Eu sou uma 
pessoa que eu não bebo, não fumo, nunca fui disso... então imagina quem faz tudo isto... deve ter uma vida bem pior do que a minha assim em relação à saúde.

Agora o corpo!!!?? No corpo assim... a pele ressecada. Você pode usar um hidratante sempre mas que a pele não tem jeito! Eu me cuido, mas mesmo assim as mãos... além dessas pintas horrorosas que aparecem... (risos) né? Essas coisas aqui... essas é...parece verruga (mostra o pescoço)... isso eu não tinha... (mostra mais outra região do corpo). Essas pinta aparece então... as mãos da gente fica muito ressecada... passo creme e não resolve muito... os seios não tem muito mais aquela sensibilidade de quando você era mais nova. Nem ao toque, nem de jeito nenhum. Então talvez seja por isso que a parte sexual fica muito limitada porque o que antes era uma fonte de prazer hoje é indiferente! Tanto faz uma pessoa tocar ou não... tanto faz. Então talvez seja isso que desilude as pessoas. Desilude eu... as pessoas menopausadas. As mulheres. Eu sinto! Pode até ser que outras pessoas não sintam mas eu to falando eu... Eu sou uma pessoa que eu me cuido muito e eu me sinto assim. Pode ser que eu não fiz assim uma prevenção e por isso eu fico assim. Na verdade eu não fiz prevenção né???

$\mathrm{Na}$ verdade eu vejo falar da prevenção mas eu não sei o que é. Mas tem aquela médica que é das mulheres... a Dra. Albertina... ela fala que a prevenção da menopausa é a partir dos trinta e cinco anos. E eu não sei agora... não adianta mais porque os trinta 
e cinco anos ficou bem pra trás então eu não sei mas ela falou que as pessoas tem que começar se prevenir com 35 anos. Talvez seja atividade física e isso eu não faço. Atividade física pra mim é uma caminhada, é uma academia, uma natação, uma hidroginástica. E nada disso eu não faço... porque quando na verdade eu pensei que eu fosse começar a fazer eu tive a limitação por conta da minha fratura. Eu tive minha fratura em 2001 e já tava na menopausa desde 96. O médico disse que a minha fratura foi diante da osteoporose. Depois eu fiz os exames por que a queda que eu tive foi muito insignificante pra mim ter tido o estrago que fez. Aí ele pediu exame e quando foi agora eu tornei fazer e confirmou osteoporose. Eu fiz densidometria e não tá intenso não mas ele falou que é pra mim tomar o cálcio enquanto eu viver. Eu sei que a caminhada e a reposição de cálcio né?! $\mathrm{E}$ mais o sol porque se não for... segundo fui informada do jeito que ele entra ele sai se você não tomar 1 hora de sol. Eu faço isso. A caminhada de acordo com minha limitação eu faço. Às vezes eu faço uma hora em ritmo lento todo dia. Já virou hábito e como eu não trabalho fora então eu consigo. Às vezes eu vou na cidade à pé... ce vê que eu moro bem longe né?! Eu vou... eu não vou trabalhar então eu vou, por que não? Ou às vezes volto (da cidade). Principalmente agora que tá frio então eu acho saudável eu sair sem compromisso com a hora pra poder fazer essa caminhada sossegada.

O que mais me chateia não sei se é atribuído à menopausa ou não, 
mas é ficar gorda, barriguda. Por mais que tente eu não consigo emagrecer. Antes dava pra perder peso. Eu não mantive um peso só... pode parecer mentira mas eu mantive um peso só durante 20 anos quando mais nova e depois que eu cheguei nos 50 esse peso meu que aumentou assustadoramente depois dos 50. Então assim... eu falava que era por conta do hormônio mas a médica falou pra mim que não, que hormônio não engorda ninguém, que é realmente os maus hábitos que a gente adquire. Então assim eu acho que a minha alimentação é muito saudável. Eu acho que a minha alimentação é super saudável mesmo por que eu ainda tenho o ácido úrico então eu procuro ter realmente uma alimentação boa a minha dieta foi feita por uma nutricionista. Eu não sigo à risca. Tem um dia que a gente sai fora, mas eu procuro fazer o melhor possível e eu não consigo emagrecer porque eu não como tanto assim pra dizer que eu tô gorda por isso. Às vezes faço exercício e não vejo um determinado resultado então eu acho que o maior desconforto é engordar e não conseguir emagrecer. Não sei se isso tem a ver né? Isso aí só através de estudos mesmo pra saber... né?

Quando eu olho no espelho vem aquela coisa assim: Pôxa vida!! eu to acabada!! (risos). Eu nem gosto muito de olhar porque assim eu não posso fazer assim uma coisa muito radical pra emagrecer porque eu tenho outros problemas que eu tomo remédio, né?! Então aí eu penso comigo: E se eu faço isso ataca aquilo então eu prefiro que eu fique um pouco mais 
gorda, mas a coisa que eu mais preservo é minha saúde. Então a gordura também não é bom mas eu sou uma pessoa que não tenho colesterol alto, eu não tenho diabetes. Eu tenho pressão alta e tomo duas qualidades de remédio ao dia por isso que eu não gosto de tomar certos remédios (pra emagrecer). Mas eu acho que a minha vida eu levo o melhor possível dentro do meu limite, mas a menopausa realmente acho que já passou um pouco né?! Mas... assim... aquele calor que a gente sente insuportável, aquele suadeira... inclusive você vê bem ela reflete tanto que já tem tempos que não tomo mais hormônios e já passou mesmo... a menopausa minha já passou né?! Acho que agora não é mais... com esse frio que todo mundo tá sentindo eu sinto calor... à noite. É calor mesmo. Aquela onda é mais fraca, dá aquele tempo, dá aquele calor aí eu descubro e passa um pouquinho já volta na temperatura normal e aí já tenho que cobrir de novo. Então não é com aquela intensidade que vinha aquela onda. Era difícil por que dá aquela sudorese de escorrer. Às vezes tá todo mundo lá batendo o queixo e a gente lá morrendo de vergonha porque ta escorrendo e vermelha é... eu fiquei uns três anos assim. E outra coisa que na menopausa dá muito é ressecamento na boca! (Faz careta) A boca muito ressecada, muito ressecada mesmo! Então assim parece que a saliva da gente parece que vai secando a impressão que eu tenho é isso... que vai secando porque às vezes a gente começa a conversar e sente que os lábios já começa a ficar seco. Eu falo que é 
da menopausa por que antes não tinha... eu tenho que levar água pra cama prá tomar à noite porque senão é uma sequidão que agente não agüenta!

Hoje eu sou mais seletiva do que algum tempo atrás. Eu sou uma pessoa muito linha dura! A minha filha fala pra mim que eu sou general. Mas é assim... na minha cabeça eu não acho que eu sou general não. Eu gosto das coisas muito certa e se eu achar que eu tô certa você pode falar comigo que é e não é. Você tem que me provar que eu tô errada. Aceito qualquer pessoa me mostrar que eu tô errada mas até que não me prove então eu é que estou certa. Agora com as minhas filhas eu acho assim que o meu comportamento agora tá mais sensível. Coisas que às vezes antes elas falavam comigo eu não levava muito em conta hoje às vezes já dói mais acho que eu fiquei mais sensível do que algum tempo atrás. Agora quanto ao meu companheiro assim é uma coisa que a gente vê pouco. Ele vive na casa dele e eu na minha... então assim... a gente não tem atritos. A nossa relação é muito boa, muito saudável, muito amiga. Devido a gente não viver no mesmo teto. Se a gente convivesse talvez seria mais difícil por que tem aquelas coisas por que o homem ele demora muito mais pra poder entrar nesse período da... andropausa né?! Do que a gente... então eu acho que deve ser muito desconfortável viver na mesma casa com alguém com ... acho que é um problema. Igual assim... a gente sente... eu penso assim se vivesse todo mundo junto... é um calor que vem dos pés da gente 
que só quem sente mesmo pra poder falar. Então... igual por exemplo: tá frio... eu quero ficar com os pés descoberto ele quer dormir coberto e ele tá sentindo frio... então eu acho que já começa por aí. Então se eu quero dormir com a janela aberta ele não quer. Ele tá sentindo frio eu é que to com calor. Então eu acho que deveria de ser problema. Eu não tenho porque ele tá na casa dele (risos) mas deve ser difícil. Nessa hora é que eu acho que essa relação é boa! Ele na dele e eu na minha. E... eu me magôo mais facilmente. Eu não tenho explicação não! É porque quando a gente é mais novo a gente acha que tudo vai resolver ali... amanhã é outro dia e...acho que agora não é bem assim né? Você valoriza muito o hoje. A vida passa muito rápido depois de uma certa idade então o que você tem que fazer é hoje. Não tem muito tempo pra amanhã. Então talvez a gente leve muita coisa assim ao pé da letra é por isso porque a gente não sabe se vai ter o amanhã pra resolver aquela situação. Quer dizer... ninguém sabe... não é só a gente mais velho... ninguém sabe da certeza do amanhâ. Mas a gente magoa mais fácil e realmente não dá prá entender não, mas a gente muda muito né?! Hoje eu tô diferente com toda a certeza. Agora uma coisa que... isso aí tem pouco tempo prá cá. Não sei se tem a ver assim com a idade ou com a menopausa ou com a vida em si... mas assim... eu tenho notado que eu quero ficar mais em paz. Comigo mesmo e com as pessoas que faz parte da nossa vida. Por que antigamente... Ah! Não gosta de mim? Problema!!!! 
(Deu de ombros) Então hoje não!

Eu não quero que a pessoa não gosta mais de mim. Antigamente eu não dava atenção à isso. Agora, hoje... eu quero viver mais em paz. Tanto com as pessoas quanto comigo mesmo. Por que a gente dessa vida não leva nada! E você começa a pôr assim muito os pingos nos "is" depois de uma certa idade. Antigamente eu era muito agitada. Hoje eu sou muito ansiosa... agitada não! É família é complicado! Hoje eu lido diferente. Hoje eu procuro assim... é que a gente tem que fazer $50 \%$ pra ver se o outro faz $50 \%$. Porque perfeito existe ninguém. Então a gente tem que aprender a viver com as diferenças. Antes eu não pensava que tinha que viver com as diferenças não! Tinha que ser daquele jeito e acabou... hoje eu não penso assim não. E como eu tô falando prá você... isso aí surgiu também não sei porque. Eu não deitei hoje e pensei: amanhã vou ficar assim. Não... aconteceu. Então são coisas que surpreendem até a gente mesmo. $\mathrm{E}$ eu fui surpreendida por isso. Não táva pensando nisso. A gente vai mudando.

\section{Você gostaria de falar mais sobre o climatério?}

Eu acho é que a gente tem mais dificuldade pra entender o que as pessoas falam. A gente tem mais dificuldade pra entender. A gente vai, por exemplo, num banco e a pessoa fala uma coisa com a gente e a gente demora mais pra entender. Então assim o que eu acho é que as pessoas tem de se preparar mais pra lidar com a gente porque com a gente é inevitável essas coisas acontece 
mesmo. Então assim é muito

difícil. Às vezes você tá falando uma coisa mas eu tô entendendo outra e não adianta eu tô entendendo é aquilo. A sua percepção fica lenta. Você não capta bem o que a pessoa tá falando. Às vezes a pessoa tá falando e olhando pra minha cara e eu ... você fica com vários problemas pra entender... pra ouvir... Então eu acho que isso aí é uma coisa assim que a gente precisa de ... eu não sei se tem um jeito assim de acelerar... pra gente assim entender melhor... eu não sei... mas isso aí é complicado. Então às vezes a pessoa pensa assim que você é burro, mas você não é. Você realmente não tá entendendo. Igual às vezes lá em casa a minha filha fala comigo e eu tô olhando pra ela mas não tô entendendo o que ela tá falando.
Aí depois... tem alguém aí??? (bate na cabeça e sorri). Aí é que eu vou ver que falou foi comigo, mas eu não sei o que falou... eu não ouvi mesmo! A gente fica mais dispersa porque eu acho... eu penso que o nosso cérebro fica muito lento e ele tem mais dificuldade pra captar as coisas. É bem devagar... a gente esquece muito né? Coisas importante que a gente às vezes não pode esquecer eu esqueço. Então eu não sei se é menopausa ou se é algum Alzheimer que vem por aí....Isto daí a gente não sabe, mas que muita coisa muda e quando você vê o negócio já tá virando um problema e é difícil pra você perceber.

Pode ser isso que me faz acordar meio triste. Pode ser por que talvez seja assim aquela ... você se sente impotente talvez... e 
você... igual eu sempre fui uma pessoa muito ativa... igual assim... eu trabalhava em dois empregos... sempre cuidei bem da casa... desde que meu marido morreu sempre fui o homem e a mulher da casa e fui, no meu ponto de vista, fui uma mãezona, realmente!! Então, de repente você sente aquela sensação de impotência. Eu acho que aquilo talvez seja o que mais te entristece... você saber que ontem você pegava isso e fazia... com essa velocidade agora... amanhã você tem que fazer um pouco e depois fazer outro pouco. Eu acho que isso daí deve de gerar uma certa frustração. Igual... um dia desses mesmo... foi sábado passado a minha filha táva viajando aí eu fiquei sozinha em casa e tinha que fazer as coisas e tomar um remédio pra dor, deitar um pouquinho, pra descansar pra poder continuar lavando louça porque não dava conta de lavar a louça... então isso aí talvez gera uma frustração na gente. E eu não dou conta... não adianta... não adianta. Eu sinto dor na estrutura óssea toda. Então se eu começo a lavar muita louça aquilo começa queimando, vai queimando e aquela dor é impossível lavar a louça. Tem que dar um tempo... parar mesmo! Então tudo isso vai te dando uma sensação de impotência... Puxa vida não dou conta de lavar uma louça mais... eu tô acabada!!! (risos) E não é? E quem quer se acabar? $\mathrm{E}$ você sabe que não depende de você! Não existe uma mágica. É difícil!! Até $\quad$ cabelo viu... pior!!! Ressecado, sem brilho. Até ele fica ruim... pior... porque já não era 
bom... (risos) até ele!! É vou pra Minas é... eu fico em casa complicado!!!

procuro ler alguma coisa é... tô freqüentando baile da $3^{\mathrm{a}}$. idade...

Você gostaria de falar mais alguma coisa?

Não estar trabalhando... no início me causou uma tristeza muito grande... depois eu pensei: Mas também eu já trabalhei muito então deixa eu ficar quieta... Então eu procurei pôr outras coisas no lugar pra mim não sentir falta porque na verdade quando eu aposentei eu já tava há 2 anos afastada então assim... não foi um baque tão grande. Mas... assim... eu fui parada bruscamente... eu trabalhando hoje e hoje mesmo eu tive que parar de trabalhar então aquilo pra mim foi.... Nossa!! Eu tive de ir até num psicólogo por que eu não conformava com aquilo. Mas depois eu comecei assim a passear igual às vezes eu eu entrei num coral da $3^{a}$. idade... então essas coisas vão substituindo. Agora isso aí já tá resolvido. Isso aí já... não sinto mais falta não. Mas foi ruim viu! Eu acho assim que quando você não pode trabalhar você acha que você tá realmente acabada porque o trabalho assim por mais que ele seja difícil... igual eu trabalhava à noite e tudo...mas sei lá... cada dia que amanhece que você dá um plantão noturno é... é uma felicidade que você tem de saber que você tá com tudo em ordem que você cumpriu sua tarefa eu pelo ao menos eu saía de um plantão eu trabalhava assim: eu trabalhava num serviço que era particular né? Eu entrava no particular às 7 da manhã, saía às 6 
da tarde, ia pra Biritiba e entrava lá às $7 \ldots$ voltava pro outro de novo e só saía de lá às 7 da noite!! Mas assim quando eu saía de Biritiba que eu via que o dia táva amanhecendo e eu cheia de vida, cheia de vigor!!! Aquilo prá mim era uma benção! Aí de repente eu caio numa cama... que eu fiquei de cadeira de rodas uns 4 meses e nossa!!! Aquilo alí pra mim foi uma morte!!! Aí depois eu comecei pensar e pensava comigo assim que era passageiro, comecei a adaptar e realmente me adaptei e agora não, agora eu tô bem nessa parte. Eu tô bem. Mas é igual eu to falando pra você... talvez amanhã você não me encontre nesse bem. Talvez amanhã eu to caída. Têm vez que eu não arrumo cabelo, ai meu Deus... quando a Ro (sua filha) fala que vai arrumar meu cabelo dá vontade chorar... é aí que eu fico pensando que é alguma coisa porque é sem motivo. Ela (a filha) fala: Ô mãe vamos arrumar esse cabelo. Eu falo: Ó Rô, pelo amor de Deus!! Deixa eu... Eu só lavo porque faz parte! Mas se não pudesse nem isso eu fazia... nem lavar o cabelo, nem tomar banho e aquele desânimo, aquela vontade... sabe? Tem hora que eu fico pensando assim: Ah! Eu vou pegar uma estrada aqui e vou andando, andando.. aí eu penso que é por isso que é tanta gente que sai de casa e não volta mais...Dá vontade mesmo tem hora da gente fazer isso... saí andando sem destino. E aí ela xinga e diz: Ai mãe tem que arrumar o cabelo... pensa bem... a senhora com esse cabelo desse jeito. Não tenho vontade, não tenho vontade de jeito nenhum!! Até que agora, já tem umas duas 
semanas pra cá eu não tô tendo essas crises não. Isso é do nada, do nada. Ó pra você ter uma idéia... a depressão ela é tão forte que acontece deles fazer festa dentro da minha casa e eu não participar. Eu vou deitar e não escuto nem que o som tá ligado. Fico lá isolada mesmo, de porta fechada, eu não quero conversar. Eu quero ficar sozinha escutar uma música... eu não gosto de televisão... ficar sozinha... eu quero ficar comigo mesmo. Então eu acho assim que todo mundo tem necessidade de ficar com ele mesmo! Mas só que parece que depois que a gente vai ficando mais velho a gente tem mais necessidade de ficar com a gente sozinho. Eu pelo menos gosto! Adoro ficar sozinha. Quando eu tô assim sozinha é o melhor remédio. O médico me passou um remédio pra eu dormir. Ele falou pra mim que era bom pra depressão. Ele falou que eu tenho síndrome do pânico... eu não sei. .. ele falou que eu tenho... ele me passou remédio e falou que com esse aqui vai melhorar e assim... até prá você dormir. Mas eu não gosto de tomar porque eu não quero ficar viciada... então se eu vejo que a coisa tá muito complicada e..se eu vejo por exemplo... que eu não dormi essa noite direito e amanhã também... aí na terceira noite eu já não quero pagar pra ver e eu tomo. Mas eu não gosto de tomar não! Eu acho assim que se eu tô quieta e ninguém vai lá conversar comigo aquilo vai passar... porque quanto mais a pessoa vem . . Eu já pedi à elas (as filhas): Não meche comigo!!! Quanto mais a pessoa quer arrancar de você o que é que você tem... tentar ajudar 
a resolver seu problema pior vai ficando... aí você começa a chorar e aí vem aquela coisa...e eu não sei da onde que vem...e aquela agonia. Às vezes quando meus neto não morava aqui.. me vinha aquela tristeza que você não sabia da onde... Aí meu genro falava: já que os menino muda pra cá...a Patrícia vem embora... aí a senhora vai ficar bem... Aí passou... minha filha veio, meus neto veio e não era isso que eu queria... e eu tô só buscando, buscando e não cheguei a conclusão nenhuma ainda... por que essa tristeza ainda me bate! Então deve ser realmente da menopausa! Eu atribuo à isso. Por que eu acho assim que você ficar... eu ficar na tristeza por que meu marido morreu não... ele não vai voltar mesmo não adianta eu ficar... e se fosse isso eu nem tinha tido uma outra pessoa. Ele morreu há dez anos. Mas eu tenho certeza que não é por isso... não é porque antes eu não tinha isso... mesmo depois que ele morreu eu não tinha essas coisas. Então foi de um determinado tempo pra cá realmente! Aí eles fala mas as criança vai vir... ih! Minha filha...tem hora que as crianças pra mim é pior. Meu Deus do céu!!! Eu não güento não!!! Tira eles daqui!!! Não é as crianças... Não é estar acompanhada, não é a presença das pessoas que me tira dessa sensação ruim... é eu mesma... assim do mesmo jeito que vem vai... É dar um tempo. Tem vez que a minha irmã mesmo que mora em Biritiba fala: Nossa eu nunca vi vc desse jeito!!! Eu falo pra ela: É que eu nunca tinha tido 50 anos...Só agora.... (risos). Aí foi sábado passado ela falou: Ah! 
Irmã mas aquele dia eu tive dó de você!!! Eu falei: Mas por que? Ela falou: Não sei...você tava com um semblante tão triste mas tão triste ... tão abatida... Mas é mesmo! Eu ponho o cabelo assim pra trás... a roupa é a pior possível que eu gosto... a pior roupa que eu tenho é a que eu visto. Por que eu acho assim que do jeito que tá minha alma eu tenho que vestir. E aquilo pra mim tá normal. Isso não é pensado. Eu vou lá no guardaroupas e... é essa aqui... não é pensado não. E ali eu vou... e olho... e digo: Puxa vida! E olho o cabelo daqui e... meu Deus... mas não adianta eu não tenho vontade eu acho que é pior porque tá contrariando aquilo que eu quero. É complicado... mas já tem bem dias que eu tô desse jeito... tô bem Graças à Deus! Pelos menos uns quinze dias eu sei que eu tô assim... Não é por que a gente quer não...Eu acho que não tem falta de nada. Eu sou uma pessoa privilegiada... apesar de eu ser aposentada eu não ganho mal... eu tenho casa... eu tenho minhas filhas que me adoram e disso eu não tenho dúvidas... elas fazem qualquer coisa por mim... tem meus genros que se eu falar que eu quero isso...eles fazem pra mim. Não! Eu não acho que me falta não... eu acho que me falta agora... daqui meia hora eu vou pesar os prós e os contra e já acho que não tá faltando. Então é igual por exemplo assim... um companheiro comigo... igual eu te falei... aquele desconforto... aquele calor... mas eu às vezes penso eu acho que eu queria um marido...pra ir comigo no baile, pra num sei o que... mas já pensou aquele homem todo o dia...ali?! 
Comida na hora certa... roupa limpa e passada... ah! não!!! Então... assim... eu acho que na verdade não me falta nada não! Eu acho que o que falta é o equilíbrio emocional e o hormonal. $\mathrm{Na}$ verdade eu acho que é isso que me falta. Por que igual... eu dentro dos limites eu tenho saúde. Igual que eu to te falando... eu tenho casa, eu tenho minhas filhas... eu tenho quem gosta de mim e isso é muito importante!! E tenho essa pessoa que tá comigo... que eu sei que ele gosta muito de mim... talvez até mais do que eu gosto dele... só que nossa situação é complicada... ele é casado...mas assim é uma pessoa que me dá muita atenção. Quando eu quebrei o pé ele foi super amigo e me ajudou em tudo que eu precisava... não financeiro...financeiro eu não preciso dele não... mas a assistência que ele me deu... então eu não sei... eu acho que eu não preciso de nada... eu acho que eu tenho o que eu preciso pra viver... eu tenho. $\mathrm{E}$ as meninas diz... vai viajar... eu digo pra quê??? Não fala comigo ir fazer um cruzeiro...eu me sinto mal só deles falar que eu tenho que ir...Ah! eu vou comprar passagem pra senhora ir...pra Porto Seguro... eu? Pra Porto seguro??? Mas a senhora tem que ir...mas eu não quero!!!! A coisa mais triste é falar que tenho que ir pra algum lugar... Eu é que tenho que resolver... se eu quero ou não. Eu sei que elas falam comigo é pro meu bem, mas eu não quero. Agora no dia 18 agora eu vou por que eu quero pra Poços de Caldas. Então a gente vai dia 18 e volta dia 20. Eu tô doida que chega...porque é uma coisa que eu que quero ir. Eles 
cansam de chamar pra vir aqui (na casa da filha). Você acha que eu venho aqui?? Não venho. Eu tenho que vir se eu quiser. Venho e fico doida pra embora. Ela (a filha) diz: mãe a senhora nem chegou!!! É mania de veio... A minha amizade é muito limitada. Eu sou uma pessoa... como se diz... sou de poucos amigos. Sempre foi... Eu tinha um casamento de uma amiga que eu disse que ia e depois fui dormir?! Pensa bem isso é coisa de maluco não é? Comprei roupa nova e até hoje não vesti. Eu acho que eu tava naqueles dias que eu não queria muito movimento. Quando eu to assim quanto mais cedo eu deitar melhor. E eu tinha vontade de ir... eu comprei roupa... fui lá no Shopping D comprar roupa... É isso. É muito superficial... Agora eu tô muito bem e daqui dez minutos eu tô... oscila muito. Meu genro tinha combinado de passar em casa para ir ao casamento. Quando ele chegou lá eu táva embaixo da coberta... então assim... é muito rápido. Eles não me forçam. Quanto mais insiste pior eu fico. Outra coisa que eu tenho ódio é eles ligarem toda hora no celular pra saber onde é que eu to: “...mãe aonde é que você ta? Que horas você vai chegar...??" É uma coisa que mais me irrita. Não gosto que me ligue, que me procura... aonde que eu to, aonde que eu deixei de tá... deixa eu... eu não bebo, eu não ando em bocada, eu não mecho com droga, eu não mecho com nada. Eu só tô em lugar bom, eu não ando em má companhia. A hora que eu chegar é essa hora mesmo! Então agora eles estão aprendendo a conviver comigo. Por que aquilo me deixava 
irritada... o controle. Eu sou uma pessoa dependente por exemplo assim: se for pra mim viajar lá pra São Paulo de trem sozinha... eu tenho medo dos outros pisarem no meu pé... por que ficou ainda um certo trauma. Isso aí eu não faço. Mas eu já não faço porque eu não sou capaz. Assim se for pra mim ir em determinados lugar a pé eu não vou, eu dependo da RÔ (filha). Eu dependo um pouco mas dependo. Mas igual quando eu vou pra Minas... eu vou sozinha! Porque é entrar num ônibus aqui e descer lá! Mas agora se for coisa de povão eu não vou. Eu deixei um pouco de passear por causa disso. Quase não passeio... eu vou num baile mas não danço com qualquer pessoa por que de repente é uma pessoa que gosta de ser extravagante e aí eu não gosto. Tem que ser do meu jeito senão não vai não. Eu tenho medo. Isso é por causa da minha limitação física e acho que não tem nada a ver com a menopausa. Agora eu quero falar da hemorragia que a gente tem antes da reposição. Em geral a gente pode ficar menstruada até mesmo com um fluxo bem grande né? Agora depois que toma hormônio normaliza tudo. Vem uma menstruação normal. Sem o hormônio é com muita cólica... é como se tivesse tendo um filho... é dolorosa essa menstruação. A partir do momento que entra no processo da menopausa ela (a menstruação) é bem diferente. Quando eu comecei eu ficava menstruada o mês inteiro. Muita cólica, coisa que eu não tinha. É um terror! Eu fiz intravaginal e não tenho problema. Acho que tava despedindo né? (risos) Ah! Eu me 
sinto tão bem sem ela (a menstruação)... nossa!!! Se não fosse todas as conseqüências de ficar sem ela... É só isso.

\section{DISCURSO 3}

TIQUE (Deusa bondosa e generosa, da felicidade e abundância, da fortuna):

54 anos, casada, dois filhos, profissão: auxiliar de enfermagem (afastada)

Tique é uma mulher muito envolvida com atividades da terceira idade. É bastante objetiva nas suas colocações.

Bem... eu até agora não tive grandes experiências. Eu não tive muitas diferenças. No começo dava aquele calor e passava... dava aquele calor e passava... Eu fui no médico e ela falou que pelos meus exames não havia nenhuma necessidade de tomar nenhum hormônio ainda então foi passando, passando e eu não cheguei a tomar. Eu tomei assim uma cartela e depois já não... não... a doutora achou que eu não devia tomar hormônio. O calor foi pouco. Foi no começo e depois passou. Eu fiquei mais calorenta depois. Então é assim: eu já não uso tanto agasalho eu já sinto mais calor normalmente do que antes mas eu acho assim... não sei se pessoas de mais idade sente mais calor. Eu passei a sentir mais calor e ficar mais sem agasalho do que antigamente mas assim aquele calor que a pessoa fala que sofre... que fala que põem os pés pra fora da coberta ... que o pé queima. Isso é só muito pouco tempo depois já não tive mais nada deste tipo de calor. 
Olha... eu nunca fui assim uma pessoa assim... muito... como diz... que tinha uma necessidade tão grande de sexo. Eu sempre fui muito... Teve uma época da minha vida que eu tirei isto (o sexo) da minha vida... achava que não devia... por motivos né... de problemas que eu tive no primeiro casamento. Então eu achei que... tirei uma parte da minha vida... depois que eu fui retomar a vida sexual. Então eu nunca fui de muita euforia não eu sempre fui mais pausada e nisso... depois do climatério pode ter... eu fiquei mais pausada um pouquinho mais. Assim... tem que me excitar bastante pra daí eu começar a ter interesse. Às vezes eu até vou ter interesse pra não contrariar meu marido do que propriamente por mim. Eu passo um bom tempo sem me preocupar. Mas eu já era assim. Talvez eu aumentei um pouquinho só. Diminuiu bem mais o interesse que eu tinha do que antes. O marido fala: Ah! Você tem que ir no médico. Eu fui na médica e ela me disse que podia me dar um remédio mas me mandou perguntar para o cardiologista se eu podia tomar. Eu fui falar com meu cardiologista e ele falou pra mim assim: Que médica é essa que vai te dar um remédio e manda você perguntar para outro médico se você pode tomar??? Ou ela sabe que você pode ou não pode tomar. Então... ele também não me passou nada pra tomar e eu acabei deixando por isso mesmo.

Quanto o sexo ainda eu sempre senti desconforto na penetração ... não é tão prazeroso... Acho que não é desconforto... eu não acho tão prazeroso. Ficou mais 
desconfortável depois... Não sei se

é por que a gente vai ficando mais... vai perdendo a umidade.... A impressão que eu tenho é que eu não cheguei a perder a umidade ainda. Eu tenho umidade. Eu acho que é desinteresse mesmo que... sem motivação. Meu marido é uma pessoa bacana, é carinhoso... pode não ser no resto do dia mas naquele momento ele faz tudo o que tem que ser feito... daí eu me empolgo... se não for assim eu não me empolgo. Por mim... eu procuro evitar confusão. Infelizmente a mulher é sempre assim né?! Ela não quer rolo e ela se faz de interessada. É mais ou menos assim.

Eu tive filhos, um parto normal, um aborto espontâneo e um parto pélvico. Naquela época o médico é que fazia os partos e mesmo sendo do INPS ele fazia direitinho.
Fez o cortinho lá embaixo. Era igual um particular de hoje né?! Então foram esses três filhos que eu tive. A minha última gestação eu tinha 25 anos. Meu filho caçula tem 29 anos. Eu não tenho neto. Só da minha enteada. Minha filha faleceu com 13 anos e meio. Hoje ela teria 33 anos. Vai fazer 20 anos que ela faleceu. $\mathrm{O}$ meu filho tem 29 anos agora e ainda não arrumou filho.

Eu não sei... sabe eu sou bastante estressada. Eu não sou muito calma. No meu dia-a-dia tem uma série de coisas que me estressam. Problemas com filho, com algum relacionamento na família, instabilidade, essas coisas todas. Então eu passei a ter mais problemas. Eu me irrito fácil mas eu não discuto muito. Eu me irrito e já falo aquilo lá na hora e pronto. Eu tô bem mais irritada. Eu 
acredito que a minha irritação... penso eu... que é devido a mais problemas que foram surgindo... que eu tenho que enfrentar esses problemas... tenho que brigar com esses problemas no dia-a-dia então fica na minha cabeça lá 24 horas me martelando então isso me irrita mais. Então eu tô bem mais estressada, tô bem com os nervos mais na flor da pele. Ou eu tô enxergando mais os problemas ou os problemas surgiram mais. $\mathrm{Eu}$ sei que estou bem mais sensível do que eu era antes.

Eu estou mais sensível sim. Por exemplo: se tem alguém chorando... eu vou aplicar injeção numa criança e a criança chora...a mãe fica...eu choro junto (risos) eu não quero... fico segurando pra não chorar... Não sei se é porque a gente fica mexendo muito com paciente e a gente acaba se envolvendo... não é que fica se envolvendo... você sente a dor da família... você vai comunicar alguma coisa pro outro... e você... eu me seguro pra eu não demonstrar que eu tô meio engasgada pra falar. Isto aflorou bem mais agora do que antigamente. Eu não sei se é pela idade Você fica assim mais mole com as coisas. Eu já tenho isto há um bom tempo.

Eu adoro banda, fanfarra... se eu vou num lugar que tá tocando isso aí... isso pra mim já é uma emoção muito forte... É uma emoção... não tem um por que causar tanta emoção mas... alguma coisa mexe comigo. Não sei se é porque me lembra o tempo de criança que eu convivi muito com essas coisas... Então isso mexe com minha emoção... bastante! 
Eu não gosto muito de retornar ao passado. Meu tempo de infância foi bom, meu tempo de adolescente se eu fizesse isso... eu era tachada daquilo...Você fica se reprimindo a adolescência inteira... pela educação que a gente teve né?! Então você se reprime de tudo: "Isto não pode fazer...., não pode olhar para um rapaz daquele jeito, não pode dar um beijo daquele jeito. O rapaz vai achar que você.... Nós tínhamos ... cheio de normas que você não podia fugir daquilo. Se você fugisse daquilo você já era tachada, então se você fosse tachada não arrumava um namorado, não casava...(risos). Eu acho que isto inibiu muito a juventude. Eu não digo pra ser igual algumas meninas de hoje em dia que fica com Deus e o mundo... mas inibiu muito a gente mesmo.... eu acho que reprimiu.... Hoje eu modifiquei muito. Depois dos meus 30,40 anos eu modifiquei muito. Hoje eu já abri minha cabeça muito mais. Hoje eu enxergo as coisas de outra forma. Não gosto de ficar lembrando as partes que eu passei com meu primeiro marido. A não ser quando alguém comenta alguma coisa mas é pouco... porque foi uma fase da minha vida muito ruim. Foram doze anos da minha vida muito ruim!!! Então depois eu fiquei uma mulher separada. E uma mulher separada é uma mulher que não presta... (Fazia expressão de exagero). Porque você não pode ir onde tem casais por que a outra mulher vai ficar com ciúmes... tem todos esses tabus...Hoje talvez não tenha tanto... mas uns tempos atrás... Eu tô com esse meu segundo marido 
há 17 anos. Eu era jovem... eu tinha 32 anos quando me separei... então eu era bem jovem né? Eu fiquei uma boa época separada e nessa época eu também não queria namorados... também eu tinha vergonha se o rapaz fosse mais novo do que eu... eu tinha vergonha do meu corpo... embora eu era bem mais magra. Hoje já não. Hoje eu tô mais liberal nessa parte porque com esse meu marido eu sou mais liberal... eu posso conversar com as pessoas todas... eu posso conviver. Tudo que ele vai fazer eu tô junto. Participamos de muitas coisas... né? Associações... agora eu já faço parte da terceira idade (Grupo/associação da cidade). Eu viajo, passeio, jogo baralho, jogo vôlei. Só não tô jogando por que quebrei meu punho... eu passeio... Então eu tô tendo mais vivência agora...embora com os mesmos problemas do lado mas eu tô conseguindo dar um pouco de espaço pra mim também. Embora os problemas vai junto... mas eu to conseguindo dá mais espaço....

No começo que eu passei... que eu perdi a menstruação eu senti falta dela (risos...) você acredita??? (muitos risos...) Por que eu achei que eu táva muito nova. Eu táva com 47 anos e eu via pessoas com 50, com 52 e ainda menstruando...eu falava: Pôxa!... a minha acabou de repente...num ano... ele veio quatro vezes no ano... e depois não veio mais porque eu tomei um remédio que a médica mandou... daí eu parei de tomar o remédio e desceu (a menstruação) eu me assustei... já tinha uns dois anos que não descia e daí desceu... e 
ficou normal de novo. E o meu útero ele ele era bem acima do útero normal... ele tinha o dobro do tamanho. E demorou pra diminuir. Agora é que tá começando a diminuir. Eu engordei... (Fez expressão de lamento). Não engordei em excesso, mas eu engordei... uns dez, 8 quilos depois que eu parei de menstruar. Talvez por relaxo meu. A alimentação é a mesma!!! Eu até diminuí a alimentação. A menstruação... eu senti falta...é porque eu acho que eu... enquanto estava menstruando eu achava que podia engravidar... essa é minha forma de pensar... eu queria muito engravidar! Mas meu marido fez vasectomia e então não engravidava. Eu tinha esperança de um dia reverter o quadro dele $\mathrm{e}$ engravidar. Acho que foi isso que fez eu ficar mais chateada quando acabou a menstruação. Apesar que eu tiro um sarro que há uns dois anos atrás nuns exames que eu fiz... falou que eu corria o risco ainda de engravidar... que eu ainda táva fértil... embora sem menstruação a médica disse que o ovário funcionava em ponto de engravidar de novo... Já pensou aparecer com um filho aí... (risos)...vou ter que explicar pois ele fez vasectomia há 25 anos né??? Eu acho que eu sentia falta (da menstruação) mais por isso. Então chegava naquele dia... era mais no final do mês.... e não tinha. É alguma coisa que me fez falta! ... por um bom tempo... depois fui esquecendo dela...no entanto eu guardei modes por muito tempo.... (risos). Eu não sei... acho que a cabeça da gente. Eu era muito regulada. Era 29 dias... se não viesse é por tava 
grávida... Ah! e... outra coisa... eu tive cólica por muito tempo depois que eu parei de menstruar... não sei se era psicológica ou se era real... mas eu tinha muita cólica antes e eu ia olhar na folhinha e era a época (de menstruar) ... Isso por um bom tempo mesmo... eu tinha os sintomas da menstruação.... não sei se é psicológico ou se tem alguma coisa assim mesmo...

Agora... o ganho de peso.... eu tenho barriga, eu não tinha... eu tenho estômago... e eu não tinha... Se eu engordo dois quilos a mais eu consigo perder esses dois quilinhos mas eu fico nisso... eu não consigo mais... aqueles quilinhos não querem ir embora. $\mathrm{O}$ que eu ganhei depois eu não consigo mais perder... eu não faço aquele grande regime também.... meu regime é vagabundo...Eu faço que faço regime e não faço. $\mathrm{Na}$ hora de vestir um vestido. Eu não ponho mais vestido. É muito raro. Eu vesti e vi que táva horrível. Eu ponho aquela roupa que segura mais. Eu visto uma blusa mais soltinha... que nem... eu to com essa blusa aqui (mostra a roupa que está usando) mas eu não saio com essa calça e essa blusa assim... eu vou pôr uma camisa por cima pra disfarçar a barriga. E o pessoal fala muito da minha bunda que é muito grande... que é muito arrebitada (risos)... Bunda eu sempre tive... quer dizer que você engordando aumenta mais ainda, né?! E quando eu era mocinha eu pesava 50 quilos... até meus trinta anos eu pesava 50 quilos... depois é que... hoje eu tô com $76 \ldots$ é bem diferente né? A diferença é muito grande. Não que eu me sinta assim tão gooooorda e 
que fico envergonhada de sair na rua por isso mas eu tento disfarçar um pouquinho. Eu acho que se você tá meio gordinha você não pode botar uma roupa que aparece a barriga... que marque muito que fica... desconfortável depois... Eu queria mudar essa barriga e os meus seios que estão mais caídos... ele também escorregou (caiu) ... não teve jeito!!!! Se eu tivesse que sair com outra pessoa que não fosse meu marido eu não sairia porque eu acho que o meu corpo tá feio!!! Então eu já acho que não ia sair com outra pessoa por que é visível... Se com 30 e poucos anos eu já tinha vergonha... eu já era retraída... então agora piorou. No meu corpo o que está ruim é minha barriga e os meus peitos que caíram... e eu acho também que é muito difícil de eu me satisfazer... com alguém!!! Sexualmente... então eu ia sair com outro pra quê??? Me causa desconforto não ter disposição... interesse... Seria importante pra mim se eu sentisse mais. Seria bom pra mim... eu acho que seria bom se eu tivesse mais interesse. Eu tentei... eu tomei o remédio e não deu certo e ficou por isso mesmo. Mas eu não sei se eu acho tão importante... por que eu não corro atrás... Eu me acomodei!! Foi isso... então eu não corro atrás!! Por que eu vou lá e a médica vai falar: "É... isso é a cabeça... é só você pensar... só você pôr isso na cabeça e o companheiro ser carinhoso que as coisas tudo rola..." Então vai rolando... Um dia rola melhor... outro dia menos e assim vai... Eu não fico pensando nisto. Sabe... eu sou uma pessoa que pouco 
paro pra ficar analisando as

coisas. Posso até tá errada. Eu sou mais assim do momento. O momento é pra resolver esse assunto então vamos resolver esse assunto. Dificilmente eu paro pra me analisar. Eu não paro pra me olhar no espelho!!! Assim tipo parar e ficar se olhando no espelho... se analisando no espelho. Dizem que é muito importante a gente conversar com o espelho... mas eu não sei se eu não acho tempo ou se eu não tenho interesse. Eu não paro pra ficar me olhando e quando eu vou me olhar eu já me acho gorda então.... (risos) eu já corto logo!!! Eu falo: Nossa!!! Eu não tinha essa banha sobrando... eu não tinha aquilo... então eu já... não fico me olhando no espelho!

Eu não costumo dar tempo pra ficar sozinha comigo mesma. Não sei!!! Eu não costumo dar tempo pra mim. Se eu to sozinha e que eu podia dar tempo pra mim até pra sentar, relaxar, assistir televisão... eu já acho alguma coisa pra fazer. Dificilmente eu dou tempo pra mim. Eu sei que eu to errada por que eu acho que tenho que dar um tempo pra mim é... passar um creme no pé... passar um creme no rosto... fazer alguma coisa pra mim!!!! Não! Eu não faço. Eu sou muito relaxada comigo. Ultimamente eu não tenho parado pra pensar. Antes eu até dava um tempinho pra mim mas com o correr do tempo... acho que eu não quero!!! Eu sempre fui agitada. Eu acho que eu sou mais agitada ainda. Quando podia dar um tempo pra mim eu prefiro fazer alguma coisa pra alguém, inventar alguma coisa pra fazer. Eu acho que se eu ficar sentada... pode vir 
meus problemas na cabeça... vai vir os outros assuntos... pode vir as coisas que eu não consegui resolver ou sei lá!!! Vai ficar sem resolver...eu vou ficar mais nervosa com aquilo na cabeça ou vou pensar em coisas passadas que eu não gosto de pensar... eu não tenho idéia!! Tem época que eu tô cansada fisicamente. Mentalmente, eu tô sempre cansada. Fisicamente eu me canso mas eu durmo uma noite de sono e... que nem... eu trabalhando à noite...eu não dormia durante o dia. A noite que tô trabalhando eu cochilo uma hora, duas horas, duas horas e meia... depende da noite...do movimento da noite... então você cochila aquilo lá eu já é suficiente... eu saio sete horas da manhã e já fazia tudo o que tinha que fazer até 9 horas, 10 horas da noite... aí que eu ia pra cama e dormia até o outro dia de manhã! Normalmente eu nunca dormi nem de manhã nem à tarde. Eu me canso mas.. então o mais cansaço é mentalmente... acho que eu me ocupo mesmo... não sei se é pra fugir dos problemas...das coisas... é uma forma de você fugir de você mesma. É uma forma de fugir. Eu não sei por que. Acho que são umas coisas mal resolvidas que eu não consigo resolver e eu vou empurrando com a barriga $\mathrm{e}$ vamos levando. Eu já fui na psicóloga umas duas/três vezes mas é assim...eu vou umas duas ou três vezes na psicóloga... mas depois... pra eu sair daqui... eu queria ir lá só nos dias que eu tivesse trabalhando... (risos... falava assim porque a "psicóloga" ficava no seu local de trabalho). Eu sair daqui, pegar o ônibus, ficar 
conversando com ela meia hora e depois voltar...!!! Ah! Não, não vou!!! Eu não dou tempo pra mim. Eu não faço aquilo que pode ser bom pra mim!!! Mas acho que... quase sempre eu fui assim viu!!!

Eu já ia tirar licença por causa do problema de coluna. Eu tenho hérnia cervical, hérnia lombar. Já fiz cirurgia lombar... então daí... na cervical o médico falou também que é cirurgia... por que eu tô perdendo o movimento desse braço direito já... eu ia tirar licença e no dia que ia tirar licença eu caí e quebrei o punho. Então eu tô de licença por causa do punho. Eu tô fazendo fisioterapia e agora eu não sei se eu vou voltar trabalhar em readaptação ou se juntando todos os problemas que eu tenho eu vou me aposentar e eu já tô pensando se eu parar de trabalhar... Em alguns momentos eu acho bom por que eu vou ter mais tempo pra fazer as novas atividades da $3^{\mathrm{a}}$. idade. Porque tem o clube $3^{\mathrm{a}}$. feira a tarde, $5^{\mathrm{a}}$. feira à tarde, sábado. Tem viagem... esse final de semana nós vamos viajar sábado pra Santos, prá São Vicente... vai ter torneio lá de vôlei... embora eu não vou participar mas meu marido vai ... eu vou participar lá né? Volto só no domingo... A gente viaja pra Marília... Então sempre tem uma vez por mês uma viagem pra fazer. E essas coisas... pra mim até que seria bom tá me ocupando nisso mas vai cair $1 / 2$ do meu salário... é isso que eu tô sofrendo...Então eu preciso ver o que a gente perde por ser acidente de trabalho ou não... E eu acho que também... eu acho que ia sentir falta...sabe... eu gosto de participar, de ta lá... eu me dei 
bem aí no (diz o nome do hospital em que trabalha)... mas só que como auxiliar... pegando peso... eu não tenho mais condições de fazer isso. Se eu pego alguma coisa eu derrubo... nessa (mostra a outra mão) eu não tenho firmeza nenhuma e essa aqui é fraca... então... eu fico pensando... o que é que eu vou resolver. Não decidi ainda... se eu entro em readaptação ou se eu vejo pra encostar...

Sobre ficar assim sem trabalhar eu não sinto nada. Se meu dinheiro vir certinho... eu não to me importando de ficar fora não. Eu sinto às vezes saudades de tá lá fazendo as coisas...né? De estar indo ver o pessoal...trabalhando. Como por enquanto eu tô me ocupando com essas coisas... eu tenho outras ocupações prá pôr no lugar... então eu não tô sentindo nada... um dia é médico... um dia é fisioterapia...e tô gostando de passar à noite dormindo...Eu trabalho no Estado desde 86... eu não tenho tempo pra aposentar ainda...e eu voltar a trabalhar tem que ser assim... de dia... numa atividade tipo fazer eletro (ECG)... tem que ser de dia... pra não atrapalhar minhas atividades... (risos...) Minha vida é super agitada!!!

Há algo mais que você gostaria de dizer sobre esta fase da sua vida? Ah! Eu participei lá no Hospital São Paulo sobre um trabalho do climatério... então lá foi feito todos os exames... tomografia, densidometria óssea... foi feito tudo... foi feito um exame que eu não sei... que dá uma cólica terrível que ele coloca lá dentro... um... tira algum pedacinho lá de dentro pra 
análise... lá do útero...sei lá... que faz uma biópsia. Dá uma cólica horrível na hora que tá fazendo... mas uma dor terrível...depois passa...não deu nada. $\mathrm{Na}$ época que começou a sair esse.. de soja...isoflavona... era prá receber isoflavona depois... eu fiz todos os exames e não deu nada ... e quando chegou na mama eu tenho na mama um nodulozinho já calcificado...muito antigo...então quando chegou na mama... acharam que tinha alguma coisa na mama. Foi feito biópsia e daí eu parei com tudo mas não deu nada... eu fiquei apavorada na época... mas fui liberada e... eu saí fora do grupo porque surgiu essa coisa na mamas. Faz uns três anos...Eu falei com a doutora lá do hospital (onde trabalhava) e ela falou que eu não precisava tomar nada... isofla- vona... que eu não tinha necessidade de tomar nada disso... então....

Os ossos tava tudo bem... . Eu caminho muito bem... eu ando prá tudo quanto é canto... Tanto que o meu punho... o médico achou que ia demorar mais pra cicatrizar e cicatrizou rápido e o movimento não tá tão ruim... não tem a força ainda... mas o movimento não ta ruim...Então... eu acho que meus ossos ainda tá bom...

Eu acho que não tem mais nada... só a menstruação que eu senti falta... você nunca pegou ninguém que sentiu falta??? (risos)... Eu ficava esperando... eu sentia cólicas... sentia todos os sintomas e não aconteceu.... (risos). 


\section{DISCURSO 4}

\section{AFRODITE (Deusa da beleza e do amor. Mãe de Eros, o cupido):}

51 anos, separada, dois filhos, profissão: Enfermeira. Afrodite é muito extrovertida. Sua expressão corporal dá ênfase à tudo o que fala. Muito objetiva e segura.

Agora eu acho que ta mais fácil de entender porque dos meus 46 47 anos foi que começou a mudança na minha vida. Eu já vinha sentindo algumas coisas que eu não sabia o que era apesar de ser da área (da saúde)... você cuida tanto dos outros e acaba se esquecendo de você. Mas na fase dos 46-47 anos eu resolvi que a minha vida tinha que mudar, que eu não queria mais ficar casada, eu não queria mais saber de relacionamento com ninguém e não queria mais viver como eu vivia, de cabecinha baixa, e resolvi estudar um pouco mais... foi quando eu fui fazer a Obstetrícia. No curso eu comecei a conhecer pessoas diferentes. As minhas professoras, as orientadoras do curso... pessoas de cabeça diferente e eu comecei a conversar e enxergar algumas coisas que eu não enxergava por que eu vivia assim... eu já era uma profissional que tinha três empregos, eu sou uma pessoa inteligente, sou uma pessoa que não é cansada... sempre estive bem disposta mas eu vivia embaixo de uma angústia, de uma amargura que eu não sabia de onde vinha e nesse período (dos 46-47 anos) parece que isso aumentou. Eu chorava muito, vivia com vontade de sumir e vivia repetindo: "eu vou embora dessa porcaria dessa casa porque 
eu não quero mais filho, eu não quero mais ninguém!!" Aí eu comecei ouvir a rádio mundial onde fala muito de como você vive, de paciência... eu pensei: puxa vida eu já sou paciente, já fui paciente minha vida inteira, tive um casamento que não foi bom porque não existia o que tinha que existir, não existia o carinho necessário, a atenção necessária, o amor necessário, mas criei três filhos maravilhosos, mas sempre ali envolta com um monte de probleminhas e sempre me colocando ali dentro. Quando eu comecei fazer Obstetrícia... acho que pelo fato de lidar com mulher eu comecei a ver que os meus problemas eram desse tamanhindo (expressa com as mãos) e que eu podia resolver... mas aí a angústia começou a aumenta, algumas coisas no meu corpo começaram a mudar e eu não sabia o que era! Me separei e fui embora morar sozinha. Depois de um certo tempo foi uma amiga morar comigo e eu comecei a sair ... aí eu comecei a conhecer ... de 46 para 47 ... eu me tornei uma adolescente... Que coisa linda! Nossa Senhora!!! Meu Deus que maravilha!!! Tudo que eu nunca havia visto na vida eu comecei a ver e o calor que me matava??!! Aquele calor... e eu comecei a dar conta do que estava acontecendo por que eu comecei a sair à noite. lá na casa de uma colega ou ia num barzinho ou ia num churrasco e era frio! Era muito frio! (refere-se ao clima) e no meio de tudo aquilo: aquele suor, um calor da cintura pra cima e uma irritabilidade, uma agonia, uma angústia que foi me fazendo ficar meia doida. Aí arrancava a roupa, arrancava a 
blusa e aquele mal estar não passava e aí eu sentia vergonha por que táva no meio de todo aquele pessoal e toda gente de 35 anos acima, eu era a mais velha de todo o grupo. Trinta e cinco acima mas eu sendo a mais velha. Então eu morria de vergonha! $\mathrm{E}$ tirava a blusa e aquele suor horroroso que escorria pelo pescoço, pelo cabelo.... Foi quando eu resolvi que eu ia ficar careca. Nossa!! Passei máquina!!! Eu digo careca assim... por que eu passei a máquina "2". Porque eu deitava... e eu não suporto cheiro de suor... posso sentir todos os cheiros do mundo mas o suor não. $E$ se eu sentir que minha cabeça tá molhada eu fico agoniada. Eu táva em festa, brincando, conversando, de repente aquele suor que escorria no meu cabelo e molhava todo o meu cabelo...
Teve uma época que o meu cabelo era quase do tamanho do seu... quando eu era auxiliar lá... meu cabelo era grande! Aquilo melava todo de suor! E é um suor horrível! Aquele é um suor pegajoso e ele tem um cheiro forte (faz expressão de repugnância). Não é esse cheiro de suor de debaixo do braço não, e nem é um cheiro de suor do gordo... é um cheiro de suor esquisito... parece que tem.... a impressão que dá é que eu tinha usado algum produto na minha pele e que aquilo estava escorrendo. Parecia gordura mesmo! Aquilo me deixava agoniada! Aí acabava a festa pra mim. Eu não sou de beber. Eu só fumava. Aí resolvi procurar o médico, fui fazer as dosagens hormonais ... quando eu fiz a primeira dosagem hormonal eu tava com $48 . .$. e eu ainda sofri todo 
esse tempo sem saber direito o que era e menstruava normalmente. Só a cor (da menstruação) que havia mudado. Não era mais aquele vermelho... aquela menstruação vermelha que não manchava. Que a minha menstruação nunca foi de manchar a roupa. De repente com 48 anos... isso eu lembro direitinho por que foi a fase de mudança na minha vida... com 48 anos!!! Eu me lembro bem que a menstruação começou a vir numa quantidade maior, num vermelho que parecia tinta e onde encostava manchava, num era pra tirar fácil como tirava com sabonete ou com um pouquinho de cândida. Era coagulosa e muito dolorosa. A impressão que dava é que eu tivesse com algum cisto de ovário ou qualquer outra coisa. Aí eu procurei o GO (médico gineco- logista) e ele pediu a dosagem de hormônio... todos os exames do climatério... eu fiz e eu me lembro que ele falou pra mim que não sabia como eu estava menstruando, por que eu não tinha no meu organismo hormônio suficiente nem pra me manter como mulher, que dirá pra menstruar! Aí ele me deu a droga Dilena... o hormônio dilena. Mas esse hormônio começou a me dar dor de cabeça... eu comecei a tomar mesmo menstruada... ele falou que não tinha problema que eu podia tomar que ia repor e eu ia menstruar normalmente... Terminava o hormônio e eu menstruaria... Durante a menstruação não tomava. Como um anticoncepcional... com isso ia diminuir os coágulos, ia diminuir a cólica e ia diminuir a minha tensão... por que eu tava um 
monstro... eu tava horrível, roxo! O pescoço... roxeava tudo nossa!!! Eu tinha adquirido um nas ondas de calor e as pessoas novo visual, havia trocado as me viam, falavam e aquilo me roupas, modificado as minhas fazia muito mal! Nem era angústia, roupas, meu cabelo havia sido nem era tristeza. Arrumei um amor cortado, a minha pele tava novo, táva feliz, sabe?! Surtei de diferente mas eu tinha dentro de verdade! Talvez eu até tenha mim uma... não era tristeza... eu descoberto naquela época quem acho que era um mal... não era era eu, por que eu não sabia quem uma tristeza. .. era um mal que eu era, não sabia mesmo. Muitas tava dentro de mim. Quando eu pessoas que me conheciam talvez me olhava no espelho eu sentia nem entendessem meu jeito por que eu já não era mais a mesma que nem eu me conhecia!! Eu pessoa e que eu estava sofrendo e corria que nem uma formiguinha. que ninguém entendia aquele Isso! Só isso! Era só isso que eu sofrimento, por que ninguém fazia. Por que era uma maneira entende... ninguém entende! As talvez d'eu esconder ou d'eu pessoas chegam e falam: "Nossa guardar ou d'eu tentar esperar me como você tá irritada! Nossa como descobrir. Muito bem! Chegou aos a sua pele tá escura..." Por que eu 48 anos para 49 tomando o dilena. sou negra! Eu não vou ficar Eu tomei o dilena um ano... aí vermelhão. Então fica vermelha a parei o dilena porque começou a maçã do rosto e a ponta do nariz e me dar... eu fumava, eu fumava o restante do rosto ficava aquele muito! Eu fumava três maços... e 
nesse período de separação, perceber que o climatério tinha chegado... as ondas de calor... eu fui aumentando a quantidade de cigarros... eu entrei com hormônio... eu... indiretamente ou inconscientemente rejeitava o uso da droga, o uso do hormônio eu rejeitava por que na minha família as mulheres nunca usaram nenhuma droga pra suportar essa fase e eu além de ser a primeira que não se mantinha casada... entendeu?! Aí é diferente... separei a família toda "tzum!!!" (fez gesto representativo de que as pessoas se afastaram) e ainda táva tomando a droga... era a única que tomava a droga (se referia ao hormônio) e minha família é uma família de cancerígenos, entendeu? Câncer de mama e câncer de colo do útero. Minha mãe é mastectomizada, eu tenho tios, eu tenho primas... as mortes na minha família, mesmo do lado masculino, é por câncer. Então, eu tabagista... tomando hormônio??!!! Ah!!! Negava, negava... aí eu acho que eu comecei a colocar muita coisa na cabeça...por que nessa época mesmo a minha tia tinha uma outra suspeita... suspeita de câncer na outra mama... então começou a me dar... talvez eu tenha até somatizado. Começou me dar umas dores no peito. E quando eu deitava, o meu batimento cardíaco era tão forte que parecia que táva batendo no colchão e um certo aperto... Mas como as minhas mamas começaram a ficar um tanto túrgidas e doía demais e a barriga, o abdome doendo bastante também... voltei no $\mathrm{GO}$ e ele falou pra mim: "Para de tomar o hormônio e toma a isoflavona!" 
Ah! Menina!! Eu tomei!!! Fui tomar a isoflavona... Nesse período que eu fui tomar a isoflavona a menstruação... menstruação parou. Eu comecei tomar a isoflavona e a menstruação sumiu. Ficou maio, junho, julho, agosto, setembro de 2002 veio a menstruação. Nossa Senhora!!! Mas muito, muita coisa!!! Eu sangrei muito, muito, muito que eu não podia levantar. Eu levantava aquilo... era coágulo! Eu falei: "Pronto! Eu tô com alguma coisa aqui! Eu vou ter... daqui a pouco eu vou ter que fazer uma histeré (histerectomia)! Aí é que eu fico louca de vez!" Fui no GO... risos... ainda ter que tirar o útero... sem ter câncer?! ... risos... Todas tiram com câncer e eu ia tirar sem??? Fui no médico e ele falou: Não! É só por que você ficou alguns meses sem menstruar... mas vai parar! Fiz exames de novo... eu táva com a dosagem boa, uma dosagem dentro do normal. Parou a menstruação... eu continuei tomando a isoflavona. Você vê que meu rosto é manchado. Isso é mancha de gravidez... só isso aqui que é sol... (aponta partes do seu rosto) Muito bem! Eu tomei mais um mês... eu já tava tomando há cinco meses... tomei mais um mês... eu percebi que as minhas manchas começaram a sumir. O buço diminuiu, o cabelo foi ficando muito fino... com a isoflavona....Eu pensei: Mas que coisa estranha!!! Mas não tinha ondas de calor, aquele mau humor, aquela angústia também já tava bem controlada... ou por que eu já tinha aprendido a lidar com ela ou por que a isoflavona táva fazendo uma reposição lenta, tardia mas táva fazendo. Aí eu comecei a perceber 
que o meu corpo não táva muito bom não!! Libido!!!??? Sumiu!!! A libido sumiu! Fui no GO de novo, fiz ultrassom e falei pra ele: Doutor eu não tenho mais desejo sexual, que que eu faço da minha vida agora? Ele falou: Não! Isso é normal... nessa idade..." e eu falei: Que nessa idade o quê?! Que nessa idade?! Agora que eu tô sabendo o que é bom da vida! Não tô velha... e não quero ficar assim! Eu não vou ficar assim doutor! Ele falou: Tudo bem... toma a isoflavona mais um tempo, vou pedir os exames e você volta pra gente tentar um outro hormônio. Continuei tomando a isoflavona! Aí chegou uma época que eu táva aqui ... no comecinho de $2003 \ldots$ fevereiro de 2003. Eu fui fazer um plantão e tinha parto à bessa pra fazer aquele dia. E não tinha ainda a enfermeira obstetra por plantão.
Eu falei: quer saber... eu vou entrar... (para fazer os partos). $\mathrm{O}$ Dr. J.M. ...táva aqui no C.O. (Centro Obstétrico). Entrei e fiz um parto. Nossa Senhora!! Quase que eu morri! Por que daí voltou... a isoflavona não táva mais fazendo o que tinha que fazer... não táva mais segurando ... Aí... entrei e fiz um parto. Saí da sala e falei: Ah! Dr. J.M. acho que eu vou morrer de tanto calor! E o pior Dr J. é que o calor tá começando... era só da cintura pra cima... agora tá vindo um pouquinho mais de baixo..... Ele falou: É normal!!! A gente já conversa já.... Fiz outro parto, fiz o terceiro parto. No terceiro parto... eu pingava. $O$ gorrinho transparente táva colado no meu cabelo. Eu saí da sala e falei (representou com gestos e em voz bem mais alta): Dr. J.M.!! Vou surtar agora!!! Vou surtar! Não 
quero mais saber de ficar sem tomar remédio! Eu vou tomar remédio é hoje! Ele falou: Por quê? Eu vou te contar... aí eu fui e conversei com ele e falei que havia notado que o meu corpo já tinha mudado tudo!!! Eu não tinha mais mancha no rosto... não tinha hormônio!! Como é que ia ter as manchas... se é hormonal, não é verdade?! Se é hormonal como é que eu ia ter? Não tinha mancha! Eu táva com cara assim que já ia virar avó de verdade... fazer crochê e tricô... Táva feio o negócio! Aí eu falei pra ele: Dr. J.M. Tá acontecendo alguma coisa estranha! A minha mama não tem mais tecido mamário. Isso eu sei! É gordura... mas... Levantei a blusa e falei: Olha pra isso que horror!!! Tá parecendo uma bexiguinha dependurada aqui!! Ele falou: Você tá tomando
Isoflavona? Eu falei: Espera... a minha genitália... eu falei: Isso que é o pior... minha genitália sumiu!!! ... risos... O quê!!! Eu falei: Não! Eu não tenho mais nada, mais nada!!! ... risos.... É sério... sumiu!!! Diminuiu os grandes lábios... os pequenos lábios táva sumindo! O clitóris? Não sentia mais... Eu falei pra ele: Eu não vou falar pro Sr. vir ver porque eu vou ficar com vergonha mas eu só tenho os grandes lábios e tô sem secreção nenhuma... nada lá pra lubrificar... e até a calcinha me machuca de tão sensível que está a minha pele!! Ele falou: Vamos dar um jeito nisso! Vamos dar um jeito... Aí nessas alturas eu já chorava... de desgosto mesmo por que eu táva muito desgostosa. Foi nessa época que o meu relacionamento afetivo acabou. Por que eu táva horrível. Nossa!! 
Eu não tinha animo, não tinha mais disposição pra mais nada! Pra mais nada, pra mais nada! $\mathrm{E}$ quando eu dei conta que o meu corpo havia modificado tanto... Nossa!!! Sabe o que é você sentar... eu fiquei 3 dias sem sair de dentro de casa. Eu não queria trabalhar mais. Não falava com ninguém. Minha amiga chegava em casa e eu não queria conversa. Eu vou morrer! Por que A.? Não, eu vou morrer! Eu viver do jeito que eu tô vivendo agora? Pra quê? Já criei os filhos, não tenho mais marido, já dispensei o romance e agora ainda olhar pro meu corpo e vê que tá caindo tudo? Não quero mais viver! Fiquei 3 dias sem trabalhar e sem ligar pro serviço, viu?! Por que eu não sou de faltar e se eu tenho algum problema primeiro eu ligo, aviso ... daí não... até nessa época eu não queria nem ver a cara da X. mais... Ela falava pra mim: Não A. calma! E eu fiquei meio... Ué que diabo!! Como é que ela pode falar que é normal se ela não sabe o que eu estou vivendo? Qualquer pessoa que se aproximasse de mim pra falar qualquer coisa eu deixava a pessoa de lado por que eu não queria enxergar o que estava acontecendo comigo. Por que é muito difícil. É muito difícil você ser uma mulher ativa... Você entende? Você ter o brilho nos olhos, seu cabelo ter brilho, você ter disposição pra conversar e de repente começar a perceber que está perdendo tudo e além de perder aquela vontade de viver você tá vendo seu corpo começar a enrugar. Eu não tenho medo de ficar velha. Por que hoje eu sei que a velhice fica aqui (aponta para a sua cabeça) mas o meu 
corpo... eu tinha que aceitar a modificação devagar e não de uma vez como foi! Imagina! O joelho... eu ficava de pé... a pele do joelho, o cotovelo, o pescoço, mão.... Hoje não. Isso aqui é mão de 50 anos? (mostra as suas mãos). Isso não é mão de 50 não, isso é hormônio viu? Isso não sou eu não! Se eu parar de tomar hormônio isso aqui vai murchar que nem um maracujá... risos... então daí eu fiz todos os exames de novo com o Dr. J.M. e ele me passou essa oitava maravilha: Tibolona Livial!!! Nossa Senhora! Voltou tudo, tudo! A libido tá assim saindo por tudo quanto é canto... risos... voltou tudo: a vontade de viver, a vontade de me arrumar, sabe? O cabelo posso começar a deixar crescer porque eu não tenho mais aquele desconforto todo. Eu trocava... eu coloquei capa de plástico no meu travesseiro... pra não molhar... o meu colchão eu tinha colocado uma capa de plástico na época do calor... e com a tibolona não. Com a tibolona foi diminuindo... Dr. J.M. falou que em 3 a 4 meses estaria começando a fazer efeito. Daí foi...foi indo... não menstruei mais. Eu ia no Dr. lá de Mogi... daí... não voltei mais naquele médico. Gosto dele como pessoa mas não deu certo comigo. Inclusive eu tomei ansiolitico na época. Com diazepan não deu por que tinha uma ressaca muito grande no dia seguinte ... eu tomava ansilive pra poder me suportar... por que o triste não é que vc não suporta as outras pessoas... você não se suporta! Você não consegue entender... apesar de não ser todas as mulheres que passam pela mesma coisa...você não 
consegue entender... no meu caso

eu táva orgulhosa de ter 50 anos e tenho orgulho de ter 51 por que minha cara não mostra e eu sou uma mulher ativa. Eu sou uma mulher que vai e acontece e resolve um monte de coisa. Mas eu comecei a me sentir como se eu tivesse me tornando uma inválida por que minha parte emocional táva no chão. Melhorou. E não era falta da afetividade por que eu tinha os meus filhos aqui com o pai, eu estava dentro de um local que era meu, que eu ia morar tranqüila, sossegada. Continuei trabalhando, estava estudando. Tava fazendo duas pós-graduação quando eu saí daqui. Táva fazendo Saúde Pública e Obstetrícia. Terminei as duas numa boa e tinha $o$ relacionamento afetivo. Então... não era falta de relacionamento afetivo.
Era alguma coisa de mim mesmo. Não táva preocupada se o mundo ia rolar pra cima ou pra baixo. Primeiro eu comecei a mudar! Eu comecei a mudar primeiro. Não foi a mudança do corpo que detonou o processo. Eu acredito que... talvez... por que eu fui uma menina que tive problemas seríssimos de hormônios. Eu menstruei com 10 anos, 9 pra 10 anos e eu tinha cólicas horríveis. Com 10 pra 11 anos eu já fazia tratamento com ginecologista. Tomava aquele regulador Xavier e outras coisas lá que a minha mãe dava. Eu tinha um distúrbio hormonal, tanto que me tornei "mocinha" e eu não tinha mamas. Eram muito pequenininhas. Eu não tinha quadril... a minha região pubiana era... eu tinha uma pilosidade muito grande. Eu tinha muitos e muitos e muitos pêlos. No pescoço, nas costas, 
braços. Hoje ainda tem um pouco. Perna, virilha, bumbum... então eu já tinha problemas de hormônio desde criança. Aí cresci e minha mãe me levou no médico e fez tratamento. Eu consegui chegar na adolescência mas eu era uma pessoa muito retraída, eu não falava, não conversava... eu era religiosa. Tinha muitos dogmas. Eu seguia uma igreja dogmática que era a Católica e tinha muito preconceito. Então tudo isso eu acho que fez com que eu me tornasse uma pessoa muito sozinha. Aí quando eu me casei (finalmente casei). Eu me casei virgem! Aí minha mãe achou que eu táva grávida e qual não foi minha surpresa quando eu fui no Go por que eu não engravidava. Todas as mulheres da família ... casou... com três meses estava grávida... eu não engravidava e nem tinha desejo sexual. Eu casei por casar. Minha mãe queria que eu casasse, eu casei. E nunca tinha tido ninguém na vida. Aí nada de filhos, nada de filhos. Aí o marido... imagina da raça de japonês... é casar fazer filho e parir... É dez filhos, oito filhos, sete filhos.... Aí fui no médico e... eu não entendo bem a infantilidade uterina... mas foi dito pra mim que eu tinha infantilidade uterina e que eu não tinha os hormônios ovarianos suficientes pra que eu pudesse engravidar e desenvolver o meu útero. Na época foi assim que me foi falado. Muito bem... eu nem sabia lá o que era estrógeno e progesterona!!! Então vamos lá! Vamos tacar hormônio na mulher. Eu já era peluda... Nossa Senhora... eu fiquei parecendo um bicho. Mas tomei... eu tomava mil unidades de hormônio por dia 
entre estrógeno e progesterona. Tomava, fiz as coisas que a médica dizia... que eu tinha que ir pra praia, sentar na praia e... aquecer o meu bumbum e depois chegar em casa e quando fosse ter relação sexual... que eu ia acabar engravidando... risos... engravidei... não sei como mas engravidei...risos... tinha que ir pra praia e ficar com bumbum sentado na areia por que aqueceria...assim diziam os médicos de Santos.... por eu morava em B., aí eu ia pra praia de manhã, ficava sentada duas horas na areia e depois ia embora pra casa... e se à noite fosse ter relação... é claro... tinha as posições certas por que além de ter infantilidade eu tinha uma retroversão uterina... então vamos lá! Fiz... fiquei grávida... lia muito... não sabia como é que estavam as coisas com meu nenê... mas sem nunca ter tido um processo inflamatório, sem nunca ter tido corrimento, sem nunca ter tido nada. Fiquei grávida... nasceu um, nasceu dois, nasceu três. Mas eu tive uma cesárea porque eu não tinha... minha bacia era muito estreita... mas era nada... era pelo convênio e o convênio paga a cesária. O segundo eu tive de fórceps, nem parir eu consegui sozinha... o terceiro foi cesárea de novo... Mas de repente... tudo isso que aconteceu talvez não fosse só pela diminuição do hormônio. Talvez já fosse a minha própria natureza. Eu sempre fui meio esquentadinha, meio confuzinha, sabe... risos..... então, de repente, até pode ter sido tudo isso... eu não sei... mas que você fica totalmente diferente, fica! Então eu não tive uma puberdade normal como a minha irmã que assumiu a 
menstruação dela... eu não... eu não assumi a minha menstruação e eu brigava com a minha menstruação o tempo todo. Eu só fui querer ficar com ela quando eu descobri que sem ela eu ia murchar. Eu só fui querer ficar com ela quando eu já tinha 40 anos. Por que daí eu já havia entendido que sem ela eu ia ter que reaprender a viver... Hoje não! Hoje eu estou bem! Tomo hormônio... com meu corpo que aumentou um pouco... mas isso é porque eu parei de fumar... faz duas semanas que eu venho pegando um cigarro e outro... Hoje eu fumei dois cigarros... eu fumava três maços. Mas hoje eu acredito que eu posso fazer isso. Hoje com meus cinqüenta e um anos eu acredito que eu posso fazer tudo. Por quê todo aquele problema que eu tinha: medo de encarar uma cartela de hormônio porque eu nunca tinha tomado anticoncepcional... medo de ficar sozinha, medo do corpo modificar. Hoje parece que isso tá ficando mais calmo. Apesar que eu não me vejo com 51. Eu não levo a vida e não tenho a fisionomia de uma mulher de $51 . .$. mas hoje eu já entendi que eu não tenho a fisionomia, o meu corpo não mostra, mas eu tenho 51. Então eu tenho que começar a ter uma vida mais tranqüila pra que quando eu chegue aos 60 eu esteja bem. Mas não é fácil não! Mas tem muita coisa que envolve. Eu acho que pra ter um climatério confuso, doente como foi o meu é por que já havia outras coisas envolvidas. $\mathrm{E}$ tem a ver com o relacionamento... que eu era completamente diferente do que eu imaginava na vida e... vida longe 
dos filhos... minha filha grávida... então acho que tudo isso influenciou muito e eu venho de uma família que tem mulheres muito problemáticas. Minha mãe é muito problemática... tenho pai e mãe... Sou a única filha legítima e tudo é na minha cabeça... então, talvez tenha havido influência do hormônio mas a minha vida pregressa contou muito. Agora nessa fase ruim da diminuição de hormônio, nossa!! Eu acordava chorando... até eu entender o que era... Depois que eu entendi o que era eu tinha raiva: Que droga... eu já vivi tanta coisa na vida e ainda vou ter que viver isso??? Agora antes de eu entender... que horror!! Nada táva bom... eu comia doce, mas eu comia doce feito uma louca. Quando não tava comendo doce eu tava fumando. Eram 60 cigarros por dia... Hoje eu me sinto bem. Eu me acho bonita, eu gosto do meu corpo. A barriguinha tá aqui mas não faz mal...risos... eu consigo ter um bom relacionamento de mulher comigo mesma. Eu aprendi a entrar na minha casa e gostar de ficar comigo... não é por que eu não pintei a minha unha que eu vou achar que tem alguma coisa de errado. Hoje eu tô bem. Gosto de curtir minha neta. Só que é assim: curto bem... ela aqui e eu lá na minha casa. Por que eu já entendi também que eu já não tô mais na fase de criar criança nenhuma. Eu não vou criar filho de ninguém. Esse filho é da minha filha e ela vai criar, ela vai fazer desse filho o que ela quer. E eu comigo, nossa!! Acho que eu nunca tive tão bem comigo. Lógico... Tem hora que bate assim uma solidão. Hoje eu moro só, Eu 
tô reaprendendo a viver. Eu acho que essa fase minha é a fase de reaprender. Aceitar algumas coisas e nessa fase eu posso fazer tudo que eu quero. Se eu quero eu quero, se eu não quero vai à m.. entendeu?! Eu não sou mais obrigada a fazer nada só para agradar alguém. Hoje eu sei que outras pessoas podem fazer o que querem, eu também posso. Então hoje eu chego na minha casa, se eu quero comer eu como, se eu não quero... se eu quiser fumar eu vou lá compro um cigarro e fumo... um cigarro... ou então vou na casa de uma amiga e falo: arruma um cigarro pra mim e não fala nada....Você me arruma um cigarro? Pego o cigarro e vou embora pra minha casa. Sento e fumo. Por que o que eu tenho feito ultimamente eu tenho feito com prazer, sabe? Eu acho que a fase agora é uma fase boa. Por que ... eu tenho mais o quê? De vida ativa?... Uns quinze anos? De trabalho... pra aposentar... dentro de uns 4,5 anos eu tô aposentando. Aí vou dar aula, se me der na louca vou estudar... mas eu ainda não consegui ainda colocar na minha cabeça que eu tenho que fazer exercício, que eu tenho que ir numa academia, que eu tenho que fazer natação. Eu ainda não senti necessidade disso. Mas eu sinto que logo, logo eu vou precisar fazer por que se eu for ficar muito tempo parada eu posso começar ter uma dorzinha aqui, uma dorzinha ali... entendeu? Eu quero viver esse período bem! Eu quase não como carne, sempre comi muitos legumes, muitas verduras, não tomo refrigerante, não bebo. Só tomo esses sucos de soja... então eu tenho uma vida 
saudável. Não saio mais à noite... passei três anos saindo à noite... que coisa boa!!!! $\mathrm{Ai}$ que maravilha!!!! Dancei bastante. Danço muito ainda. Só que hoje eu já começo a sentir que um esforço maior já me cansa. A noitada já não dá mais e se eu for eu sei que não dá, eu sei que eu vou chatear quem estiver comigo... Tem uns quatro meses que eu não saio à noite. Beber eu não sou chegada mas sair e ver o povo dançar... isso eu gosto. Então eu acho que de agora pra frente eu vou viver bem.. tô comprando minha casa... sei como vai ser minha sala, como vai ser meu quarto.... A gente tem que ter ocupação. Eu vejo minhas vizinhas com a minha idade.... Quase caí pra trás outro dia... vi uma mulher de 52 anos... nossa! A mulher tá um caco. Aí fiquei olhando pra ela... sem atividade não dá! Mas agora eu tô bem. Tô me dando melhor com a minha filha...com meus filhos...com meu ex-marido eu já converso bem, com meu pai e minha mãe...Eu me tornei uma outra pessoa, mas uma pessoa melhor! Agradeço à tibolona também, né?!!!... risos....É claro... e ao Dr. J.M. que salvoume... risos...Já pensou eu toda pelancuda, já pensou?! Não ia me suportar, olhar no espelho e ver meu pescoço caindo... ah! Não! Agora não! Tá tudo em cima.... Tenho brilho no olho... tô apaixonada... Se não fosse a tibolona não tinha paixão. Se eu continuasse do jeito que eu estava com todos os problemas que eu vivi? Nossa Senhora!! Eu me descobri sexualmente, você entendeu? Eu vi que era outra coisa... a própria sociedade, meu pai, minha mãe...talvez mais a 
minha mãe... que, de uma maneira muito boa coitada, por que não foi nada por maldade, não deixou eu tomar as minhas decisões. Por que eu venho de uma geração que o pai e a mãe mandavam. Então talvez se eu tivesse tomado as minhas decisões na época certa... talvez eu não tivesse vivido o que eu vivi... Mas como tudo aconteceu como tinha que acontecer... isso tudo pode ser... mas como eu sou diferente das outras mulheres da família...então tinha que ser... Eu sou especial... Hoje eu sou assim muito especial... Das fases da minha vida esta é a melhor. Olha eu continuo do mesmo jeito. Sempre bem humorada, levantando o astral de quem precisa... mas hoje eu levanto o (astral) do outro mas o meu também tá lá em cima... Mesmo que eu me sinta... é lógico que tem hora que qualquer ser humano... não é questão de climatério, não é questão de menopausa... qualquer pessoa de vez em quando se sente só. Então, tem hora que eu me sinto só mas... tem o celular, graças à Deus!!! Quando eu tenho crédito...risos... então a gente vai vivendo, mas bem! Gosto da minha casa, gosto das minhas roupas. Você sabe que eu mudei muito. Eu não sou mais aquela A.... Eu não sou mais a "a". (no diminutivo)... acho que até o nome acompanhava. Hoje não! Hoje eu só "A". mas só "A". Porque eu assumi ser a $A$. Hoje, quando me chamam de a. (no diminutivo) eu volto lá no passado... eu respondo, mas eu volto lá no passado e vejo o quanto eu mudei! Mas tudo foi muito bem. E eu tô saudável pra encarar essa minha terceira 
idade....que vai ser daqui mais ou

menos 15 anos...eu tenho mais quinze anos pra viver ativamente... prá que quando eu chegar lá eu possa estar tranqüila e viver uma fase de cada vez. Por que nessa época a minha neta vai estar com, se Deus permitir que eu esteja viva até lá, minha neta tá com 4 anos, ela vai estar com 19 anos... quem sabe eu já seja até bisavó... do jeito que a coisa tá! Mas tá bom. Hoje eu cuido dos meus pais com muito mais tranqüilidade. Ganhei um respeito muito maior dos meus pais e também das pessoas que me cercam. Sabe, eu acho que eu cresci muito nessa fase do climatério. Eu ouvi alguém falando na TV que essa é a pior fase da vida... ou a melhor... porque é a segunda adolescência. Que coisa boa!!! Nossa!!! E o bom é que a melhor parte disso é que quando você é adolescente pela primeira vez você não tem respostas. $\mathrm{Na}$ segunda fase da adolescência você encontra as respostas. Você é mais você! Eu posso sair. Se eu quiser sair. Se eu falar: Eu vou sair com aquela pessoa. Eu vou sair com aquela pessoa... Eu hoje vou lá pra São Paulo, eu vou ficar sentada lá na Av. paulista só olhando os carros passarem... Eu posso ir fazer. Eu sou dona do meu nariz. Então eu posso surtar quantas vezes eu quiser porque sou eu que me sustento, eu me mantenho e hoje eu descobri que em algumas horas... eu me basto. Em algumas horas não. Em algumas horas você precisa de uma companhia. Mas em algumas horas eu me basto, em algumas horas eu não quero ver ninguém. E posso me dar ao luxo de dizer: eu não quero conversar... Eu me 
tornei uma profissional muito mais maleável. Mas isso a Obstetrícia me ajudou bastante também. Por que nessa fase do climatério eu fui justamente cuidar de mulher. E fui encarar a mulher diante de um momento muito difícil, né?! Quando eu começava a ver elas assim sofrendo aquela regressão e se tornando uma criança de 12 anos eu ficava pensando: $\mathrm{O}$ que são os hormônios no corpo da gente?! Naquela época, que eu não sabia direito o que estava acontecendo. Aí, depois eu fui me descobrindo, fui conhecendo... eu não conhecia meu corpo... eu vim me conhecer quando eu entrei nessa fase do climatério. Depois que eu me separei. Aí eu fui prestar atenção em tudo, fui ver o que estava acontecendo... Eu acredito até que eu tenha começado, eu tenha entrado nesse climatério com uns 44 anos... mas eu não me observava, eu não prestava atenção. Eu só vivia pros outros...Hoje não! Hoje é como eu falei... a gente nunca tá pronto pra morrer. Claro que não! Mas se por acaso tivesse que falar: Pronto! Eu tô pronta!... é claro que eu ia pedir mais um tempo, ne'?! Mas... eu falaria hoje: Estou! Eu já criei meus filhos, eu criei uma mulher que tem uma filha mulher, que viveu comigo tudo o que eu vivi... que entende muito bem... Os meus filhos são muito bem orientados a respeito do climatério. Todos eles sabiam que ia acontecer. Tanto que o meu menino que está fora do país agora falava: Ê mãezinha... isso é só o climatério!!! É que eu dei palestra na escola deles quando eles eram crianças. Eles tinham tudo bonitinho... todos os sinais e 
sintomas precoces... eles tinham tudo anotadinho no caderno... então não foi tão difícil com os filhos. Se eu tivesse ficado com o ex-marido teria sido difícil por que ele está com 50 anos e ele nunca foi muito paciente e eu teria curtido tudo isso dentro de casa e aí teria enlouquecido. Mas foi o melhor surto da minha vida!!! A segunda adolescência é tudo o que um adolescente quer. Eu usava blusa de linha, blusa de lã, calça de lã, eu não vestia jeans. De repente... surtei de verdade... comprei blusinha decotada, calça de cintura baixa... só não consigo usar tênis, e um sapatinho de saltinho, bonitinho... engraçadinho... coloquei um cinto e vim aqui. Nossa!... e cortei o cabelo... Nossa Senhora!!! Minha filha morreu de ciúmes... Nós morávamos aqui... foi quando eu saí... Ah! Meu ex-marido começou a encher o saco, eu falei: Quer saber? Fica com seus filhos aí! Tô indo embora... fui!!!! Eu conversei com meus filhos e falei: "Essa fase da vida é minha.Vocês têm a casa de vocês. Eu não tenho o direito de tirar o conforto de vocês pra resolver a minha vida.Então (falou pra filha)... você tá grávida, você tem seu quarto, você tem suas coisas... Os dois meninos a mesma coisa... eles concordaram e eu fui embora. Catei minhas coisas, botei dentro do carro, nossa!!! Que coisa!!! Saí assim, no meio de um surto,aquela angústia, aquela coisa... mas feliz...Como se eu tivesse quebrando um par de correntes. Fui embora! Aliança eu já não usava mesmo...aí eu falei: Não! Quando eu cheguei lá (na outra casa) eu comecei a pensar o que que eu tinha feito?! A minha 
filha ficou com ciúmes e ela não conseguia entender que eu estava passando por uma fase minha. E boa! Não que eu tenha deixado eles. Porque eu táva longe mas eu ajudei... eu continuei vindo pra cá o tempo todo, fazendo tudo o que tinha que fazer... e o povo metendo o pau em mim... Mas a minha filha teve problema sério. Mas encarei numa boa, venci... e hoje... com certeza... hoje eu me sinto vitoriosa... e apaixonada... não é uma coisa linda?!! Fala a verdade.... risos... E ainda apaixonada. Nossa que coisa diferente!!! Madura. Eu não posso dizer que... eu acho que isso não é nem paixão... eu acho que é um amor por que hoje eu aceito até dividir, desde que eu esteja bem na hora que eu precisar estar bem, que eu não tenha ninguém dormindo na minha cama, nem morando na minha casa. Fique lá... vem vê, vamos sair... vamos passear, vamos brincar... vamos ter uma vida adulta... e eu tô bem. Tenho medo? Tenho!! Tenho medo de ficar sozinha e não ter com quem conversar. Tenho medo de sentir uma dor e não ter pra quem ligar. Entendeu? Mas isso já sou eu a A. que tem um monte de medo, um monte de neura... mas o meu lado hormonal hoje ele tá bom, ta controladinho... Não sei até quando eu vou poder tomar isso... e eu não tô com medo de câncer não viu? Eu não! O povo já morre de câncer sem tomar hormônio! Minha mãe nunca tomou hormônio na vida... minhas tias também não! E eu falo que todas elas são "despeitadas" ... arrancaram um (são mastectomizadas)... risos... tem que levar na piada... Os homens da família que morrem é 
câncer de esôfago. Meu pai tá com

câncer de próstata... tá controlado.

Foi retirado os testículos mas ta bem. Eu fui obrigada a assistir a cirurgia! Sabe o que é você ver arrancando os testículos do seu pai? Por que ele não deixou eu sair da sala. A gente pensou que ele fosse dormir mas ele não dormiu. Então eu fiquei lá! Fiquei mal, mal... Depois dessa cirurgia eu fiquei dois meses quase sem dormir direito...mas eu sempre fui assim "táqui" (agitada). Eu só deixei de ser assim na fase da angústia, mas com a reposição.... Eu acho que hoje é uma vivência maior, madura... Talvez não tão madura por que "eu não caí do pé" (expressão que diz que o fruto maduro cai da árvore)...risos... caí sim... lembrei... mas é verdade que é uma adolescência. É a segunda adolescência! Pode ter certeza que é. E hoje, durante as minhas aulas eu posso falar por que eu vivi! E eu ajudo muita gente. Eu só gostaria sabe do quê? Que tivesse alguma maneira da gente poder orientar essa mulherada pra que quando tivesse vivendo...por que quando você passa a saber o que você tem, você consegue se controlar um pouquinho. Para poder ajudar essa mulherada que tem por aí a entender, a encarar esse climatério tão filho da mãe...risos.

\section{DISCURSO 5}

HÉSTIA (Deusa do lar e da lareira sempre acesa):

54 anos, separada, nenhum filho, profissão: empregada doméstica. Héstia é bastante simples e tímida. Está fazendo supletivo (está aprendendo a ler e escrever 
agora). Disse que é casada, mas no decorrer da conversa fala que está separada do marido. Tem dificuldades de se expressar e pronunciar algumas palavras. Explico o que significa climatério e menopausa. O tempo todo ela fala na terceira pessoa. Mostra-se bastante resignada com sua condição social e afetiva.

Pra mim tá sendo assim.... no começo começou a esquentar as mãos e depois das mãos começou a "descer" atrasado... um mês atrasava.... As mãos começaram a esquentar e até hoje ela queimam. Então primeiro começou assim, né?!... aquela caloria nas mãos parecendo febre...insuportável... mas só nas mãos. Depois começou assim um pouquinho nos pés... Daí... sobre todas essas fases que tem acontecido comigo de eu ter começado as mãos esquentar vários tempos na frente aí minha menstruação começou a parar... vinha um mês sim e outro não... depois ficava dois, três mês sem vim e vinha... e depois não vinha... Passava cinco, seis mês e daí parou de uma vez. Foi embora de uma vez só e não teve retorno. Depois dessa fase pra mim... eu acho que ter ido embora (a menstruação) eu acho que não foi bom por que a mulher começa a sentir dores na perna ela começa a sentir...... não se sente bem, sente canseira. Então prá mulher ter ido embora (a menstruação) pra ela não é uma coisa boa porque começa doer dos dedão do pé até a coroa da cabeça então não é bom pra ela.... então o normal seria é que não fosse embora (a menstruação). Eu sinto falta porque eu me sentia bem 
quando tinha a menstruação regular... era sempre regulada... aparecia naquele dia certo... era uma coisa certa mas depois disso eu não me senti assim com saúde.... é sempre com uma coisa, uma dorzinha aqui e outra acolá... Pra mim que sou assim meio caipironazinha...(risos) tudo simples... eu achei que nunca precisasse tratamento médico... Eu nunca pensei em procurar médico por que eu acho assim que não precisa por que eu sou normal... Eu acho que é normal. A temperatura das mãos fica forte e depois vai embora e eu acho que é normal e não precisa tá ocupando os médicos... Como eu não tive filho nem nada eu acho que eu não preciso fazer esses tratamento tão rigoroso assim da menopausa... assim por que falaram pra mim que tem um tratamento que faz, né?! Sobre os "homonicos"... eu nem sei dizer a palavra direito.... Eu achei que quem não tinha filho não precisa porque pensei assim mais ou menos... que só quem tem filho... quando a menstruação vai embora elas passam mais tempo menstruando... elas passam oito dia, dez dia, quinze dia.... Pelo que elas contam é assim exagerado como se fosse assim uma hemorragia. Eu não tive hemorragia e elas tem hemorragia. Eu acho que é que eu não tenho assim problemas mais sério por causa de eu não produzir...Se eu produzisse podia ser que eu precisasse ocupar um médico pra fazer tratamento. Mas eu achei que não precisava e eu sempre me sentia bem e quando foi embora foi de uma vez... não ficava oito dia, dez dia, quinze dia 
descendo... quando foi embora foi de uma vez... foi normalmente... foi embora! Eu não tive filhos. Nunca consegui engravidar por causa que meu marido não quis que eu tratasse, né? Precisava fazer um tratamento tanto nele como em mim... e ele não aceitou a proposta de querer fazer um tratamento... se o problema era ele ou eu mesmo até hoje eu fico na dúvida... eu não sei ...se o problema sou eu ou ele... ficou difícil pra eu saber por que ele não aceitou tratar... os anos foram passando e... Agora com a menopausa eu acho que na saúde muda muito por que a mulher quando tem suas regras normalmente ela é uma pessoa mais saudável. Eu acho isso por que eu acho que a menstruação da mulher é a saúde da mulher... desde o momento que vai embora eu acho que não fica mais aquela saúde que ela tinha. Ela começa a mudar... a gente sente assim dores na perna, calores no pé. $\mathrm{Na}$ época do frio as mãos esquentam bastante inclusive ó... (encosta suas mãos no meu rosto. O dia estava frio.) elas ficam assim que nem que tá com febre. No corpo não... só nas mãos. Eu menstruei com 13 anos e terminou cedo. Agora com o marido..., assim sobre ter relacionamento... nessa fase assim... hoje eu sou separada e eu não tenho contato com meu marido mais e eu tô parada nesse sentido há dois anos... assim... sobre os desejos carnais modera... a mulher fica mais moderada, mais calma, não sente aquele coisa assim como quando ela menstrua. Quando ela não fica menstruada ela fica diferente... ela fica mais calminha, mais fria... tem caloria 
mas não é uma caloria como antigamente no começo da mocidade. O marido não cobrava nada... ele não achou diferença e nunca reclamou sobre esse sentido mas a mulher não fica aquela coisa que ela era, né? Às vezes a pessoa fica irritada, nervosa... sei lá é uma coisa muito estranha né? Fica muito assim irritada, tensa. Isso é de vez em quando. Quando alguma coisa que eu tenho que fazer e não dá... quando eu fico tensa que nem agora quando você chegou aqui eu fiquei nervosa. Eu moro lá na Serra do I. com a família lá. Eu tenho dois sobrinhos... um eu criei ele...Eles ficam sempre olhando por mim... por que eu hoje me encontro separada do meu esposo né porque assim também... não tinha nem como eu ficar grávida também... mesmo se eu for uma mulher normal... porque eu não sei até hoje... até hoje não encontrei defeito nenhum em mim e por que na época eu era jovem e ele (o marido) não aceitou tratar na época... então eu não sei o meu defeito. Então fica difícil saber que defeito eu tenho. O que eu sei nessa parte aí... que eu fui passar na médica e tudo e ela falou que eu era uma mulher normal como qualquer uma outra... que na época que eu podia menstruar e que eu podia ter filhos com um pequeno tratamentozinho que se meu marido fosse fazer tratamento tanto dele quanto meu mas se ele não comparecesse não tinha como assim fazer um tratamento... e ele não quis e eu fiquei triste por causa disso por que eu queria ficar grávida. Eu queria ser mãe... risos... e quando as regras deixaram de vir eu pensei assim... 
agora que não tem mais (as regras)... agora é que não vai mais ter filhos mesmo né? Daí a idade vai passando... são $40,45, \ldots$ e a mulher vai chegando numa situação que ela não pode mais ter filhos, né? Ela vai ficando velha... mesmo que fique grávida ela fica com mais dificuldade pra ter 0 filho... então passava tudo isso na minha mente... que eu não podia ter filhos... com 50 anos.... apesar que a minha mãe teve um filho com 51 anos, né?... Mas ela deve ter menstruado mais tarde e ter ficado mais tempo menstruada... por que conforme a menstruação é que indica se a mulher pode ter filhos ou não né? ... e eu me sinto só... por que meu marido foi embora de minha casa... ele me abandonou... ele era uma pessoa alcoólica também... né?! Por causa que se eu tivesse tido filho talvez eu tivesse uma companhiazinha pra mim dentro de minha casa ou talvez nem tinha, né?! Porque vai casando os filhos mas... os netos... vem visitar, né? Eu tenho um filho de criação que eu peguei com 7 anos de idade... já criado... da minha irmã... minha irmã teve 25 filhos... nossa!!!! ...risos... ela é que teve os filhos... eu não tive. Ela teve 25 filhos e criou-se 7 , né? Porque no nordeste as criança é fraquinho e desidratado então eles morre, né?! Eles adoece ou tem febre alto... um sarampozinho... então elas morrem mesmo não tem jeito! Aí tinha uma das criança que o pai num ligava muito pra ele e aí ela me perguntou se eu não queria cuidar dessa criança... nessa época eu estava com meu esposo... Ela disse: Ah! Leva ele! Se você levar você vai tá fazendo uma caridade não pra mim mas 
pra ele! Eu disse: Tudo bem! Se for pra te ajudar eu vou te ajudar mas se meu marido aceitar por que ele vai trabalhar pra ajudar cuidar da criança. Aí como nós não tinha filho meu marido ficou todo balançado e disse "Vâmo pegar ele sim e vamos levar ele (pra São Paulo). Aí nós criamos. Ele hoje tá casado e tem 3 filhos. Ele é meu filho, eu tenho uma nora muito bonita com os olhos azul e tenho os netos. Meu sobrinho é muito bonito. Um moreno bonito, claro de olhos verdes. Muito bonito! Ele mora vizinho. Nenhum mora comigo depois que meu marido foi embora mas eles estão tudo de olho em mim.... Ele é meu filho do coração! É muito bom isso aí! Agora é que eu tô com problema de diabete e colesterol essas coisas... que foi me dá agora depois dos 50 anos por que eu não tinha diabete.. eu não era diabética. E agora me causou esses problemas que eu não sei se é por que agora eu não menstruo mais ou então... Eu tô tratando... minha pressão é alta e a pressão alta já é irmã, companhia da diabete. Eu tô fazendo tratamento de 3 em 3 mês eu faço exame, tô medicada. Acho que é só isso.

\section{DISCURSO 6}

ATENA (Deusa da sabedoria, das artes e das guerras justas):

49 anos, casada, duas filhas, profissão: estudante de enfermagem e técnica de enfermagem. Atena aparenta ser muito tranqüila e de bem com a vida. Se separou do primeiro marido, com quem teve duas filhas. Há mais de 20 anos vive com outro companheiro. 
Cuida da mãe e irmã que são parcialmente dependentes. Está cursando o último ano da graduação em enfermagem e é bem independente e decidida. Gosta de estar sempre bem arrumada e comunica-se polidamente.

Então... eu fui uma criança que nasci prematura e com 10 anos de idade veio a minha primeira menstruação. No começo vinha assim a cada três meses, quatro meses... mas sempre em datas precisas, não era irregular. Com onze anos mais ou menos começou vir em datas certinhas. Então eu nunca tive cólicas, nunca sofri com cólica. Eu fui uma menina assim sempre super normal.... aí... eu casei com 16 p/17 anos... muito novinha né?! Engravidei e minha gravidez foi tudo normal também... nunca tive vômitos, nunca tive nada, nada! E... nem assim contrações... nada! Nem contrações, pra saber assim se eu estava em trabalho de parto, eu não tive. Minha bolsa rompeu, eu fui internada... eu fiz cesárea. O médico fez cesárea por ele achou que tava na hora, né? Pela dilatação, tudo normal... mas sem cólica, sem nada. Depois tive minha segunda menina daí há um ano e pouco... bem rápido e também como a primeira, sem cólica, sem nada, foi tudo normal e foi cesárea também. Pra evitar eu sempre evitei com tabelinha ou camisinha. Nunca tomei nada, nada, nada. Depois, quando eu tinha antes um pouquinho de trinta e sete anos, minha menstruação não veio, eu estranhei muito, eu achei até que eu estivesse grávida. Achei esquisito, né? Por 
que sempre foi muito certo... achei que eu estivesse grávida. Mas daí fui ao médico e ele falou assim que eu tava entrando na menopausa precoce. Aí esperou mais um pouco por que minha menstruação vinha assim a cada três meses e sempre em data certinha, com diferenças de um a dois dias às vezes. Quando eu tava mais ou menos com 38 anos parou! Aí foi quando ele entrou com tratamento de hormônios né!? Foi Fórmula... eu fiz assim uns seis meses de tratamento com hormônio. Depois disso ele mandou que eu parasse, fez todos os exames e mandou que eu parasse e mandou que eu tomasse chá. Chá de folha de amora que eu tomo até hoje por que dizem que é um hormônio muito bom, né?! É a folhinha, você toma a folhinha, chá! Olha eu nunca tive aqueles problemas de fogacho, aquele calor eu nunca tive! Nunca tive nada disso e tenho uma vida normal. Por exemplo, eu nunca fiquei assim uma mulher frígida, nada disso, tá?! Pra mim foi assim tudo muito normal. Eu acho que do mesmo jeito que foi bem normal começar a menstruação com 10 (anos) de idade foi normal assim até o final.... Por exemplo, eu vejo muitas pessoas falarem que fica assim... é... com a vagina muito ressecada. Eu nunca tive nada disso. A libido normal... sempre normal.... então eu acho até estranho... Sempre foi tudo muito normal pra mim. Quando vejo as pessoas contarem eu acho até meio estranho por que pra mim foi sempre tudo muito normal. A ausência da menstruação em si não faz falta porque desde menina 
eu queria ter dois filhos. No começo eu achava que queria ter um filho só mas depois eu tive a primeira menina e em seguida eu engravidei... a mais velha tinha sete meses. Eu não queria assim tão rápido... eu engravidei e falei: Olha, eu só quero dois filhos e pronto! Então eu tive a segunda menina e pra $\operatorname{mim}$ assim... eu sempre quis duas meninas... engraçado né?... risos... a determinação do sexo vem do pai, não é isso? Não vem de mim...mas eu queria duas meninas e tive minhas duas meninas... então pra mim eu achei até que foi bom!... risos...sabe... com sinceridade eu achei que foi bom... eu achei que fiquei livre, entendeu? Eu não queria mais filhos... aquela preocupação, aquele medo de engravidar acabou, né? Então eu tinha muito medo de engravidar mas então aí (com o fim das mentruações) eu achei que foi ótimo. Uns dois anos eu ainda fiquei com um pouquinho de medo e falava assim: E se acontecer alguma coisa!!!!... Eu tava com uns trinta e nove (anos) e deixou de vir mesmo... acabou, acabou mesmo e isso eu achei ótimo em todos os sentidos... Então... eu achei assim... eu achava até engraçado por que... a minha filha também casou muito nova. A mais nova casou muito nova e.... e aí nessa época ela táva esperando neném e eu achava engraçado pra mim... eu falava: Nossa que engraçado eu não tenho nem mais menstruação... eu sou tão nova ainda, sabe aquela coisa?... Então aí eu comecei a pensar um pouquinho... mas só nessa época! Eu falava: Nossa a maioria das pessoas que casaram novas igual 
a mim tem netos mas têm menstruação e eu não tenho....! Eu achava engraçado por que quando ela engravidou e foi justamente a época em que minha menstruação parou... a primeira vez assim que parou... eu achei assim que tivesse grávida. Eu fiquei meio assustada. Eu falei: Já pensou? Minha filha grávida, eu grávida...?! Então eu não achava legal não, sabe? Eu não sei porque. Eu acho que é por que eu queria só duas filhas e eu achava assim meio esquisito se eu tivesse grávida e a minha filha grávida. Então eu entrei assim um pouquinho em depressão. Foi a única época que eu lembro assim... eu fiquei meio em depressão e eu fui ao médico... Ela (a filha) indo ao ginecologista toda feliz e eu indo preocupada. Aí fiz exame, fiz tudo o que tinha que fazer e não era gravidez e eu achei ótimo. Mas assim ... com meus familiares... tudo normal. Aqui em casa a gente brincava muito... eu e o V. (o marido) então... eu achei que pra mim foi tudo normal. Eu sou uma pessoa muito calma, eu falo assim que eu sou bem feliz por que eu estou bem comigo, feliz com a vida! Eu sou assim... eu vou estudar .. eu gosto de estudar com música... Eu vou levantando... a primeira coisa... eu venho aqui e coloco uma musiquinha... Então é o meu jeito e eu acho que isso também contribui pra... Eu fiquei assim um pouco triste porque eu engordei e ninguém gosta de engordar, mas eu sempre tentei controlar... Eu nunca fiz regime, não tomo remédio. Ultimamente eu engordei um pouco mais por que eu estou ansiosa porque... assim... no término da faculdade... Eu sempre 
fui gordinha mas acho que engordei assim uns dez quilos nesses anos que foram passando. Agora vou voltar na hidroginástica... fui lá ontem... e eu perco um pouco (o peso) só que eu ganho com facilidade... Eu estava até comentando com a minha filha... sabe aquele sedentarismo? O sedentarismo mata, né?! Eu levanto de manhã, tomo meu banho... vou ler alguma coisa, depois vou na minha mãe.... e tudo o que eu faço é sempre no carro. Eu tenho minha mãe que tá doente. Ela amputou a perna e eu tenho uma correria grande e então é assim... vai levar um exame, vai... sabe aquela coisa?... Por isso que agora eu já marquei a hidroginástica já um pouco pra mim... pelo ao menos três dias da semana... pra mim. É aqui perto. Todo mundo fala assim.... a pessoa é bem gordinha por que come muito...eu to comendo erradamente e não muito... eu sei disso. Mas a gente que sai de casa, vai fazer estágio longe... a gente realmente come erradamente, come o que tem na hora e aí você faz uma alimentação super... Trabalho à noite e... tudo errado... Eu sou bem agitada... mas eu poderia assim fazer uma caminhada... mas eu sou meio preguiçosa de sair sozinha... e acho que isso... Uma época eu comecei fazer caminhada, eu e uma vizinha... eu perdi três quilos... É uma coisa que eu tinha que ter continuado. Daí eu parei por que voltaram as aulas... eu não consigo caminhar sozinha. Eu levo o carro pra lavar em Suzano e vou olhar as lojas e ando um pouco. Eu entro lá no lava-rápido, sento, fico batendo um papo, tomo 
um guaranazinho... risos... olha aí...tudo errado! Mas eu quero fazer yoga também...eu já entrei em tantas academias... e sabe esses exercícios assim... eu não agüento fazer... eu caí da escada... faz tempo... e fraturei o cóccix... então tem exercícios que não dá. Mas eu tenho que fazer alguma coisa. Do ano passado pra esse foi muito... por que minha mãe... sabe aquela pessoa que faz tudo?!... Depois ela teve esse problema e teve que amputar as pernas... então ela ficou muito dependente, muito carente...eu tenho uma irmã que com 28 anos teve derrame, teve três derrames e tem um lado todo paralisado. Ela era muito dependente da minha mãe e agora ficam, ela e minha mãe, dependentes de mim... então fica difícil. Aí eu parei muita coisa, sabe?! Eu tenho netos, tenho três netos...e eu tô com 49 anos e mesmo com a menopausa eu nunca me senti velha. Eu lembro da menopausa quando eu falo da menopausa. Você vê... com a idade que eu estou... eu fui pra faculdade, eu... eu nunca me senti velha...não sei se... eu menstruei muito novinha, eu me casei muito novinha, eu criei meus filhos... aquela idade assim... eu criei minhas filhas como se fosse irmã. Eu já criei todo mundo e agora quem vai estudar sou eu. Quando eu comecei fazer faculdade a minha outra filha fez pedagogia. Eu sempre fui uma pessoa assim muito pra cima. Eu falo assim: Gente eu só lembro da menopausa e da minha idade quando eu falo sobre isso... Eu fiz aniversário e eu falo: É... vocês colocam data (aponta para as orquídeas que ganhou)... aí eu 
lembro da minha idade!... risos.... Eu nunca me preocupei... eu falo a minha idade... tem gente que não fala... Então eu sou uma pessoa assim tranqüila e de bem com a vida... O meu grupo de estágio é muito desanimado e eu pergunto pra eles: Gente! Será que isso é idade?!... risos...Eu me sinto muito bem obrigado!!!... risos.

\section{DISCURSO 7}

\section{DEMÉTER}

(Deusa

da agricultura):

51 anos, casada, três filhos, profissão: costureira. Deméter é bastante independente e sempre trabalhou como autônoma. Esperou o término da entrevista para pedir orientações sobre o que poderia fazer para ter saúde nesta fase. Preocupava-se ainda com o risco de gravidez. Ela e o marido usam preservativo (condon) pois temem uma gravidez nesta fase. Está em amenorréia há 2 anos.

Pra mim eu acho que a única diferença pra mim é... da menopausa, não é isso? Normal. A única coisa de diferente que eu sinto é alguns calorões que dá né? Um ambiente muito fechado já começa a me da aquela... mas do contrário normal. Em relação à nervoso assim eu sou um pouco agitada, sempre eu fui né? Meio agitada, meio nervosa mas isso é normal também. Não mudou muita coisa não. A única que eu senti diferente mesmo foi os calorões. Às vezes eu ponho coberta, tiro coberta, ponho roupa, tiro roupa, mas fora disso nada de diferente. Há dois anos eu não mênstruo e quando a menstruação parou logo veio os calorões. Parou de uma 
vez. Nunca mais voltou nada. Parou de uma vez! Pra mim que eu tenho uma vida agitada eu encaro normal. Somente os calorões que me atrapalham, me sufoca mas é coisa passageira. Tem dia que eu fico sem, tem dia que dá mas normal. Qualquer horário acontece. Às vezes dormindo você tira a coberta daqui a pouco passa e você já coloca e assim vai normal, não tem dia nem hora e, agora como marido e mulher não me atrapalhou em nada não. Normal também. Em relação aos filhos e como dona de casa eu dou conta de tudo, faço tudo e além de muito mais coisas. Eu cuido de tudo. A falta da menstruação, pelo contrário, eu até fiquei mais livre... por que todo mês é aquele compromisso agora eu to mais tranqüila... só que tem mos calorões que me atrapalham às vezes... risos...De lá pra cá, após a menopausa, às vezes eu sinto a minha barriga tremer. Muito assim... a barriga... sabe quando você tá esperando nenê que às vezes dá aquela tremidinha? Mas eu tive foi ganho de peso quando eu parei de fumar. Eu fumei por 23 anos e há 11 anos eu parei de fumar e foi aonde de 60 eu fui para 95 quilos... eu tenho certeza que foi por que eu substituí o cigarro por outros hábitos... de comer... Eu tenho certeza. Mas tudo normal por que a gordura não me atrapalha também nas minhas atividades. Eu não tomo nada e não fui ao médico por causa da menopausa. Nem pros calorões eu nunca procurei tratamento. Veio normal vai ter que acabar normal, eu penso assim! E é uma coisa que dá pra mi agüentar, não me atrapalha também tanto não é? É 
uma coisa que vem e vai rapidinho. A menopausa é a única coisa que me atrapalha mas eu acho que do mesmo jeito que vem esses calorões eu acho que um dia eles acabam não é? Tem um tempo que ele passa (as ondas de calor) não tem? Ou acaba ou então a gente se acostuma, né? Das duas uma né? Eu acho que cada um é cada um. Cada pessoa agüenta de uma forma. Que nem minha mãe também na época ela não fez tratamento nem nada ela começou também a menopausa dela e foi aonde até que ela engravidou do meu irmão caçula com 39 anos e acabou assim sem nada também, sem fazer tratamento. O que ela se sentia era assim mesmo, esses calorões que dá. Mas é coisa passageira! Eu acho que a menopausa pra mim... por que se me deixasse bem fora de série eu já teria procurado o médico. Mas eu acho que pra mim eu acho que dá pra agüentar até o final. Se for assim né? Agora de aumentar eu tenho que procurar. Eu tive também... ressecamento... às vezes eu senti. Acho que umas três vezes eu senti isso na hora do relacionamento. Eu sentia assim seca, sabe?! Aí eu perguntei pra minha irmã, que ela é enfermeira também e ela falou que isso é normal mas ela acha que eu devo de procurar um médico. Mas eu to me sentindo tão bem, eu não tenho nada! Só senti três vezes (o ressecamento vaginal) e depois não mais... e o relacionamento assim (sexual) normal como sempre teve. Não é coisa assim de todos os dias. Isso aí (a relação sexual) é uma coisa assim bem estudada. Nada me atrapalhou no sexo. Eu sempre acho e eu 
sempre falei desde o início do meu casamento que o sexo é uma coisa muito bonita e muito gostosa desde que faça com prazer e com amor. Não é uma coisa como se fosse arroz e feijão todo dia e toda hora. Então eu acho que nesse ponto eu e meu marido a gente se combina muito bem. Também não é o caso assim de uma vez por semana por que também eu acho que eu sou bem nova pra isso mas eu acho que é bem normal. Nem eu nem ele tem o que se queixar. Agora esse ressecamento aconteceu umas três vezes e na hora do ato sexual eu senti mesmo... mas também.... não fiz nada e passou. Percebi e... porque percebe viu! É um ressecamento que não tem como.... dói... não tem como. Eu até estranhei e falei que se continuasse eu sou obrigada a procurar mas não senti mais nada.
A única coisa que eu mudei foi a alimentação que eu tirei o sal. Eu sou hipertensa então eu pra evitar eu já... A minha sogra faleceu e foi comigo, no hospital. Justo quando ela faleceu eu tava ali e quando ela tava ruim mesmo eu fiquei ruim e aí me internaram ali do ladinho dela... eu fiquei ali. Minha pressão foi à mil. Isso faz tempo... uns nove anos... bem antes da menopausa. O médico me passou remédio que até hoje eu tomo. A única coisa que eu tomo pelo médico é o higroton mas nada. Eu mesmo tenho o aparelho, eu me sinto bem e tomo direitinho o remédio. A pressão sempre ta normal. Eu faça assim um chazinho de vez enquanto com chuchu, cozinho muito chuchu com a casca né? O coraçãozinho do chuchu é bom também.... eu vou levando... Todo dia eu tomo um 
higroton e uma vez ou duas vezes por semana eu tomo um chá... por que eu sou muito agitada eu tomo um chá de melissa... e assim vai. Eu tive quatro partos e cinco filhos. O primeiro parto meu foi duas filhas gêmeas... nasceram de oito meses e aí... elas se foram... morreram... (fala com detalhes e emocionada sobre a experiência do parto e de como foi o falecimento das filhas). Foi um passado triste na minha vida. É como eu te falei não adiante procurar explicação por que não tem. O que tem que ser da gente é... Aí eu não engravidava depois delas eu não engravidava... eu fiz muito tempo tratamento e o médico me disse que eu tinha as trompas entupidas. Ele falou pra mim ir no consultório e fazer o tratamento e assim foi feito. Eu gastei tudo o que eu tinha e o que eu não tinha por que eu queria um filho. Eu fazia o tratamento por três anos. Aí ele (o médico) me desenganou e me encaminhou para o hospital da mulher... aí eu me desesperei e chorei, chorei como se tivesse morrido alguém muito próximo. Aí a vó do meu marido, que era dessas pessoas muito antigas, ela foi conversar comigo e eu chorava e dizia: Ai vó eu queria ter uma filho e o médico me desenganou. Eu tô sentindo que o meu casamento vai acabar!!!" Eu não tinha dor, corrimento, nada!!! Então ela me ensinou um remédio e disse que tudo tem um por quê. Que não me desesperasse e confiasse em Deus e pediu para irem buscar um remédio de homeopatia na farmácia lá em São Paulo e trouxe três vidros. O remédio chama João da Costa, é um líquido preto de 
raízes... um mês e meio depois eu tava grávida. O médico não acreditou mas eu tive minha primeira filha, depois das gêmeas. Eu falei pro médico: Dr. Eu tô grávida! O senhor me desenganou mas Deus não!!! Eu acho eu isso pros médico não é tão importante, né? Mas pra mim, não sei se é meu psicológico... Quando ele me desenganou foi como se tirasse o doce da boca de uma criança. Eu fiquei super decepcionada, magoada, passar o que eu passei que não foi por dias e sim por anos... Não tinha dinheiro que chegasse. Depois quando a minha filha tinha seis meses eu engravidei de novo e perdi... era gêmeos de novo. Depois eu tive mais dois filhos. Eu gostaria muito de ser mãe mais uma vez... risos.... mas eu tenho medo porque eu sou hipertensa, né? Depois da menopausa eu tenho medo de engravidar. Eu me previno... por que minha mãe fala que quando parou de vir pra ela (a menstruação) ela não se preveniu e ela engravidou do meu irmão e eu fiquei com medo... Então não tem problema? Porque ele (o marido) é meu único parceiro, eu sou a única parceira dele... será que têm problema? Foi até bom você vir aqui por que meu marido falou pra eu fazer essa pergunta pra você. Ele usa preservativo por que eu tenho facilidade pra ter filhos... eu não dou trabalho pros médicos. Mas eu tenho medo porque eu sou hipertensa. Eu tenho vontade assim de pegar uma criança por que a gente sente falta. Minha caçula ta com 20 anos... mas... Depois que eu tive os três filhos eu não pensei em ter filho mas se acontecesse... só agora eu tenho medo. Se 
acontecesse eu ia chegar no médico e pedir uma cesárea porque é mais previsível, mais planejado... e uma cesárea é a mesma coisa que cortar um dedo e levar quatro pontos... concorda? Eu acho que o prazer de um parto é um parto normal! Mas se acontecer é obra de Deus né???? Aí vai ser uma surpresa...Você vai vim e fazer uma outra entrevista comigo... risos... Agora não vou usar mais camisinha... risos... por que minha menstruação quando vinha era sete a nove dias de sangramento mesmo fortíssimo... todo mês. Então eu acho que foi radical também quando parou parou de uma vez!! Às vezes eu sentia uma dorzinha leve nas coisas mas levinho... eu nunca tive tempo de nem saber o que era TPM... risos... Eu acho que o problema maior também tá nas pessoas procurar os problemas, né? Por que de repente me dá uma dor de cabeça e eu ficar repetindo que eu tô com dor de cabeça. Tô com dor de cabeça... não!! Vai tomar um remedinho e vai procurar cantar, fazer um serviço, esquecer aquilo que aquilo vai sarando aos pouquinhos... agora tem pessoas que lida muito com problemas e eu acho que ajuda bem o psicológico. O que eu gostaria de falar é que dói muito bom os esclarecimentos e comigo graças à Deus ta tudo bem . Graças à Deus eu não sou aquela mulher de procurar médico. Tenho uma marido maravilhoso, uns filhos maravilhosos, passei pelo o que eu passei mas eu acho que eu tinha que passar por que tudo é um aprendizado pra gente, né? Tudo é uma experiência, uma lição de vida!! 


\section{ANEXO B \\ TERMO DE CONSENTIMENTO LIVRE E ESCLARECIDO}

Título da pesquisa:

Vivenciando o climatério: o corpo em seu percurso existencial à luz da fenomenologia

Eu, Roselane Gonçalves, professora de Enfermagem na área da saúde da mulher e aluna de Pós-Graduação da Escola de Enfermagem da Universidade de São Paulo, estou realizando a pesquisa que tem como objetivo compreender a vivência da mulher durante o período do climatério.

Sua participação será muito importante para que nós, profissionais da área da saúde, possamos conhecer o que acontece com as mulheres que vivenciam o climatério e, dessa forma, podermos contribuir na assistência prestada.

Para tanto, necessito realizar entrevistas que deverão ser gravadas a fim de facilitar o registro das informações. Assumo o compromisso de manter sigilo quanto à sua identidade, pois todas as informações coletadas serão identificadas com códigos fictícios de conhecimento apenas do pesquisador. 
$\mathrm{Eu}$, após ter recebido os esclarecimentos fornecidos pela pesquisadora e ter entendido o que foi explicado, consinto em participar da presente pesquisa.

Também tenho conhecimento de que será mantido meu anonimato, que não terei prejuízo em participar deste estudo, que terei a liberdade de deixar de participar da pesquisa a qualquer momento, que seu resultado será utilizado em eventos e publicações científicas e, ainda, que a pesquisadora se colocou à disposição para os esclarecimentos que se fizerem necessários pelo telefone 4790-1534.

Este documento possui duas vias, sendo que uma ficará em meu poder e a outra será arquivada com a pesquisadora.

Assim, declaro que tendo compreendido o exposto, concordo em participar da pesquisa e não me oponho que a entrevista seja gravada.

Assinatura do participante do estudo:

Data:

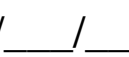

Assinatura da pesquisadora COREN-SP n. ${ }^{0}$ 50180:

\section{Comitê de Ética em Pesquisa da Escola de Enfermagem da USP}

Av. Dr. Enéas de Carvalho Aguiar, 419 - Fone 3066 - 7548 
ANEXO C 